Gianfrancesco Genoso

\title{
PRINCÍPIO DA CONTINUIDADE DO SERVIÇO PÚBLICO
}

\author{
Dissertação de Mestrado
}

Orientadora Profa. Dra. Odete Medauar

Faculdade de Direito da Universidade de São Paulo - USP

São Paulo

2011 


\title{
GIANFRANCESCO GENOSO
}

\section{PRINCÍPIO DA CONTINUIDADE DO SERVIÇO PÚBLICO}

\begin{abstract}
Dissertação apresentada para a conclusão do Curso de Pós-Graduação Stricto Sensu em Direito do Estado da Universidade de São Paulo, sob a orientação da Professora Dra. Odete Medauar, como requisito parcial à obtenção do título de Mestre.
\end{abstract}

SÃO PAULO 


\section{O PRINCÍPIO DA CONTINUIDADE DO SERVIÇO PÚBLICO}

$$
\text { por }
$$

Gianfrancesco Genoso

Dissertação apresentada como requisito parcial à obtenção do título de Mestre, no Curso de PósGraduação Stricto Sensu em Direito do Estado da Universidade de São Paulo, à Banca Examinadora formada pelos seguintes examinadores: 


\section{RESUMO}

Esta investigação tem por objeto o estudo do princípio da continuidade do serviço público. Inicia-se pela definição de serviço público (e de serviço público essencial) e os princípios que regem a prestação dos mesmos. Aborda-se a matéria em relação às leis de concessões e os direitos e garantias dos usuários dos serviços delas decorrentes, somadas às garantias constitucionais e consumeristas. Enfrenta-se o problema da interrupção do serviço público por inadimplemento e o direito de greve, em face do princípio da continuidade. No intuito de cumprir tal tarefa, realizou-se cuidadosa análise dos entendimentos doutrinários nacionais e estrangeiro, adotando-se o método analítico. As técnicas de pesquisa utilizadas, por sua vez, foram a bibliográfica, em livros e artigos extraídos de revistas especializadas, através da qual foram reveladas as semelhanças e as oposições existentes entre os entendimentos formulados pela doutrina. Por fim, manifestamos nosso entendimento sobre o assunto.

Palavras ChaVeS: Princípio da continuidade do serviço público. Prestação de serviços públicos. Garantias constitucionais e consumeristas. 


\begin{abstract}
This investigation has as main objective analyzes the principle of continuity public service, facing the problem of the interruption of essential public service because of the default and the right of strike. Starts studying the definition of essential public service and its principles taking to account the concession law, the rights and guarantees of the consumers and the constitutional precepts about the subject. Intending to fulfill this duty, it was made a carefully analyses of the national and foreigner authors, using the analytic method to examine these documents. The bibliography method had revealed resemblances and differences between the authors' opinions and the rules of law that are related in the conclusion of this research.
\end{abstract}

KEYWORDS: Principle of continuity public service. Essential services providing. Constitutional and consumerists garantees. 


\section{SUMÁRIO}

RESUMO.

ABSTRACT

INTRODUÇÃO

1 ESTADO, FUNÇÃO PÚBLICA E SERVIÇOS PÚBLICOS. 11

1.1 Função pública. 11

1.2 Serviços públicos. 15

1.3 Prestação dos serviços públicos 25

1.4 O Estado como prestador de serviços e o Código de Proteção e Defesa do Consumidor.... 34

\section{PRINCÍPIOS ADMINISTRATIVOS.}

2.1 Princípios: força normativa e particular relevância no âmbito do direito administrativo..... 41

2.2. Princípios constitucionais explícitos versus implícitos. 48

2.3 Princípios da preponderância do interesse público e da indisponibilidade pela Administração Pública dos interesses públicos. 50

2.4 Princípios da proporcionalidade e da razoabilidade. 59

2.5 Princípio da eficiência. 63

\section{PRINCÍPIO DA CONTINUIDADE DO SERVIÇO PÚBLICO: PRIMEIRA} APRESENTAÇÃO.

3.1 Princípio da continuidade e princípios guias do regime jurídicoadministrativo 
4.2 A suspensão do fornecimento de serviço público essencial por inadimplemento do usuário e o princípio da continuidade...

4.3 A excecptio non adimplenti contratus e o serviço público. 101

4.4 O equilíbrio econômico-financeiro do contrato de concessão. 103

4.5 O direito de greve, os serviços públicos essenciais e o princípio da continuidade.

4.5.1 A greve no funcionalismo público e a jurisprudência do Supremo Tribunal Federal... 107

4.5.2 A greve dos servidores públicos e o princípio da continuidade

4.6 A continuidade da Administração Pública sob outro enfoque: a substituição nas funções públicas.

4.7 Perfil e objeto do princípio da continuidade: notas de encerramento 


\section{INTRODUÇÃO}

O presente trabalho tem por objeto o princípio da continuidade do serviço público, a ser estudado a partir de uma perspectiva maior, que é a dos principais princípios guias do direito administrativo.

Defende-se aqui que a escorreita compreensão do princípio da continuidade - significado, abrangência, limites e conformações - é decisiva para a concretização dos princípios basilares da atuação da Administração, em particular o da eficiência, permitindo que, mais eficaz e habilmente, a Administração possa atingir seu objetivo maior, que é o da realização do bem comum.

O trabalho vai estruturado em quatro capítulos, seguidos das considerações finais.

O primeiro capítulo cuidará de estabelecer algumas idéias gerais (sem a pretensão da completude ou do esgotamento) a respeito do papel do Estado, da função pública e dos serviços públicos. No mesmo passo, enfrentarse-á a difícil questão em torno do conceito do serviço público essencial, bem como se tratará da problemática em torno da submissão do Estado, enquanto prestador de serviços, às regras do Código de Proteção e Defesa do Consumidor (Lei 8.078/90).

No segundo capítulo cuidar-se-á de apontar a influência dos princípios gerais do direito na estruturação e compreensão do sistema jurídico como um todo e, em particular, com acentuada força e relevância, no regime jurídico-administrativo. A ausência de um 'código' regente da matéria e, portanto, sistematizador das regras guias para o (bom) atuar da Administração Pública releva o alto grau de importância dos princípios dentro do Direito 
Administrativo Brasileiro, exigindo, por isso, alguma atenção aos mais importantes deles.

O terceiro capítulo será dedicado a uma primeira apresentação do princípio da continuidade do serviço público, a partir da análise e tentativa de identificação de sua origem, fundamentos normativos e, especialmente, das relações que se estabelecem entre a continuidade e outros princípios guias do regime jurídico-administrativo.

No último capítulo, já assentadas algumas importantes premissas, serão enfrentadas das repercussões do princípio da continuidade do serviço público. Sob essa perspectiva, o Capítulo 4 destina-se a examinar o princípio da continuidade em cotejo com a inadimplência do usuário do serviço público, a possibilidade de conciliação do princípio da continuidade como direito de greve dos servidores públicos (art. 37, inc. VII da Constituição Federal) e, por derradeiro, estudar os institutos da delegação, substituição, interinidade e suplência, analisando os requisitos necessários para tanto e as implicações daí decorrentes.

Por derradeiro, serão apresentadas as considerações finais e notas conclusivas.

Optou-se por diluir, ao longo do trabalho, referências ao direito estrangeiro (lei e doutrina), no lugar de um capítulo - estanque e sem diálogo ou aproveitamento com os demais itens e questionamentos de nossa pesquisa apenas tratando do que se comumente denomina de 'direito comparado'.

O método de abordagem a ser utilizado será o dedutivo, na medida em que a partir de uma premissa consistente em um valor universal, algumas conclusões lógicas serão alcançadas a respeito do tema proposto, empregando-se, quanto ao procedimento, o método analítico, apoiando-se na concepção dinâmica da realidade e das relações dialéticas entre teoria e prática. 
As técnicas de pesquisa utilizadas serão embasadas especialmente em levantamento bibliográfico, em livros e artigos extraídos de revistas especializadas, que analisados deverão revelar as semelhanças e as oposições existentes entre os entendimentos formulados pela doutrina, nacional e estrangeira bem como pelo exame da legislação, confrontando-a com a estrangeira.

Em suma, espera-se que as questões que se apresentam, e a respeito das quais será desenvolvido o presente trabalho, relativas à delimitação e aplicação do princípio da continuidade, permitam compreender o real significado de tal postulado, sempre com vista ao atendimento dos interesses dos administrados e à permanente busca da boa Administração. 


\section{ESTADO, FUNÇÃO PÚBLICA E SERVIÇOS PÚBLICOS}

\subsection{Função pública}

O estudo do princípio da continuidade do serviço público pressupõe, antes de tudo, voltar os olhos para institutos fundamentais com vistas a tentar precisar-lhes os contornos, ainda que de maneira bastante sucinta: o de serviço público e, porque lhe está umbilicalmente associado, o de função pública. Mas, antes ainda, para que se possa bem compreender o objeto central deste trabalho, é fundamental iniciar-se com um exame - igualmente perfunctório - em torno das funções do Estado.

Atribui-se a Montesquieu a ideia da separação dos poderes do Estado $^{1}$, na tentativa de, distribuindo as funções, evitar qualquer tipo de abuso. É a adoção clara do sistema de freios e contrapesos (checks and balances). Com tal divisão e individuação dos órgãos, afasta-se a noção de predominância ou prevalência de um sobre os outros - como já se verificara no Brasil de outros tempos - e tem-se mais proximamente as de independência, harmonia e, porque não, equilíbrio e mútuo controle.

No Brasil, essa divisão foi assumida em vários e sucessivos textos constitucionais. ${ }^{2}$ Atualmente, na Constituição da República de 1988, está

\footnotetext{
${ }^{1}$ Conquanto antes de Montesquieu pensadores como Locke, Rousseau e até mesmo Aristóteles tivessem cogitado dessa separação, à Montesquieu atribui-se correntemente a divulgação ou consagração de tal postulado. Ver, a respeito, José Afonso da Silva, Curso de Direito Constitucional Positivo. 25. ${ }^{\text {a }}$ ed. São Paulo: Malheiros Editores, 2005, p. 109.

${ }^{2} \mathrm{O}$ princípio da separação dos poderes foi assumido na grande generalidade das Constituições do mundo ocidental, como pontua Diogo Freitas do Amaral (AMARAL, Diogo Freitas do. Curso de Direito Administrativo. 7. ${ }^{a}$ reimpressão da ed. de 2001. Almedina: Coimbra, 2007, vol. II, p. 12). Isso significa, segundo o autor, que nestes países tal princípio "encontrou uma tradução no plano do Direito Constitucional, e outra no campo do Direito Administrativo." (Ibidem, mesma página). Em outras palavras: "No plano do Direito Constitucional, o princípio
} 
bastante clara nos dizeres do art. 2. ", onde se lê "são poderes da União, independentes e harmônicos entre si, o Legislativo, o Executivo e o Judiciário." Tal princípio assenta-se em dois elementos, consoante clássica lição de José Afonso da Silva: a especialização funcional, significando que cada um dos órgãos é especializado para o cumprimento de sua função e a independência orgânica, expressado pela ausência de meios de subordinação. ${ }^{3}$

A compreensão atual deste princípio, porém, sofreu e sofre significativas mutações e porque até não dizer, sensível atenuação. Já se foi o tempo em que tal princípio era lido com peculiar rigidez. O Estado ampliou seu raio de atuação (alcançando, mais modernamente, os campos social e econômico, exigindo a adoção de alternativas, como a descentralização de atividades estatais); ademais, surgiram novas 'figuras', como se verá adiante. Esse quadro impôs uma revisão do conceito "clássico" da tripartição, análise esta que, no entanto, escapa dos lindes e objetivo deste trabalho.

Calha trazer anotação importante feita por Agustín Gordillo, no sentido de ser mais adequado falar-se em separação de funções do que propriamente separação de poderes. O poder é uno, anota com propriedade. ${ }^{4}$ À vista dessas colocações e dos elementos representativos do princípio da separação de 'poderes' (rectius, funções), passa-se à delimitação e conceituação de função pública.

Segundo Celso Antônio Bandeira de Mello, funções públicas "são plexos unitários de atribuições, criados por lei, correspondentes a encargos de direção, chefia ou assessoramento, a serem exercidas por titular de cargo efetivo,

da separação dos poderes visou retirar ao Rei e aos seus Ministros a função de legislar, deixando-lhes apenas a função política e a função administrativa." E prossegue: "No campo do Direito Administrativo, o princípio da separação dos poderes visou a separação entre a Administração e a Justiça, isto é, retirar à Administração pública a função judicial e retirar aos Tribunais a função administrativa." (AMARAL, Diogo Freitas do. Curso de Direito Administrativo. Almedina: Coimbra, 2007, vol. II, pp. 12-13).

${ }^{3}$ SILVA, José Afonso da. Curso de Direito Constitucional Positivo. 25. ${ }^{\text {a }}$ ed. São Paulo: Malheiros Editores, 2005, p. 109.

${ }^{4}$ GORDILLO, Agustín. Princípios gerais de direito público. São Paulo: Saraiva, 1977, p. 110. 
da confiança da autoridade que as preenche (art. 37, V, da Constituição)". 5 Podese dizer, em linhas gerais, serem atribuições que a Administração Pública confere a seus agentes e servidores para a execução de determinados serviços já predestinados ao atendimento das necessidades dos administrados.

Deve-se atentar, porém, para a polissemia da expressão "função" na seara do direito público. É correntemente utilizada, ora para indicar uma atribuição ou competência de um órgão, ora para indicar determinado fim a que se destina a atividade do órgão público; diz-se, também, por função o exercício do poder destinado ao atendimento de um fim (interesse alheio, da coletividade) ${ }^{6}$ - sendo este o significado que se tomará neste trabalho, para entender a função pública precisamente como o exercício de atividades pelo Estado, atividades essas dirigidas a um fim especificamente delimitado. ${ }^{7}$

\footnotetext{
${ }^{5}$ MELLO, Celso Antônio Bandeira de. Curso de Direito Administrativo. 27. a ed. São Paulo: Malheiros Editores, 2010, p. 255. Para referido autor, em seguimento: "Assemelham-se [as funções públicas], quanto à natureza das atribuições e quanto à confiança que caracteriza seu preenchimento, aos cargos em comissão. Contudo, não se quis prevê-Ias como tais, possivelmente para evitar que pudessem ser preenchidas por alguém estranho à carreira, já que em cargos em comissão podem ser prepostas pessoas alheias ao serviço público, ressalvado um percentual deles, reservado aos servidores de carreira, cujo mínimo será fixado por lei." (Ibidem, mesma página - os grifos são do autor).

${ }^{6}$ Celso Antônio Bandeira de Mello registra que onde há função "não há autonomia da vontade, nem a liberdade em que se expressa, nem a autodeterminação da finalidade a ser buscada, nem a procura de interesses próprios, pessoais. Há adstrição a uma finalidade previamente estabelecida, e, no caso de função pública, há submissão da vontade ao escopo pré-traçado na Constituição ou na lei e há o dever de bem curar um interesse alheio, que, no caso, é o interesse público; vale dizer, da coletividade como um todo, e não da entidade governamental em si mesma considerada.

(....) Visto que na ideia de função o dever é que é predominante; visto que o poder a ele ligado cumpre papel instrumental, ancilar, percebe-se também que os 'poderes' administrativos, em cada caso, não têm por que comparecer além da medida necessária para o suprimento da finalidade que os justifica." (Ibidem, pp. 97 a 99 - grifos do autor).

${ }^{7}$ MEDAUAR, Odete. Direito Administrativo Moderno. 11. a ed. rev., atual. e ampl. São Paulo: Revista dos Tribunais, 2007, pp. 107-108 (grifos da autora). Mais adiante, a autora assinala, com total propriedade: "mediante a ideia de função o poder administrativo apresenta, portanto, conotação peculiar, pois canaliza-se a um fim, implicando, além de prerrogativas, deveres, ônus, sujeições." (Ibidem, mesmas páginas - grifos da autora). Em outra passagem deste mesmo trabalho, a autora deixa evidente seu conceito - deveras preciso, e neste trabalho adotado - de função pública, nos seguintes termos: “(...) função pública significa o exercício de atividades da competência da Administração, em nome desta e de acordo com as finalidades desta, ou seja, para atender ao interesse público.” (Ibidem, p. 261 - grifo da autora)
} 
Ainda a esse respeito, é válido acrescer - como pontuado por Diogo de Figueiredo Moreira Neto - que "Os estatutos, em geral, como, por exemplo, o Estatuto Federal vigente, não conceituam a função pública em sentido autônomo, o que vale dizer que nem todas as funções públicas correspondem necessariamente a cargos específicos, como, por exemplo, as funções de jurados, de mesários eleitorais, de escrivães e oficiais de justiça ad hoc, de tradutores juramentados etc. Referem-se, porém, os estatutos, à função pública, como um conjunto de atribuições acrescidas a cargos públicos, como sejam as de direção, de chefia e de assessoramento (e.g. art. 39, §§ 1. ${ }^{\circ}$ e $2 .^{\text {o }}$; art. 61, I; e art. 62 do Estatuto Federal)." ${ }^{\prime 8}$ Acatamos inteiramente essa opinião, a qual adotamos para este trabalho.

Para o objeto e limites deste trabalho, há de se compreender a função pública como a atividade destinada à realização dos fins havidos como essenciais pelo Estado (visando, portanto, um fim de natureza "coletiva"). Ademais, à vista da tripartição tão apregoada por Montesquieu, é possível distinguir e reconhecer as funções públicas em funções legislativa, jurisdicional e administrativa. Ou, como prefere Ana Maria Goffi Flaquer Scartezzini, "a função pública, em seu exercício, traduz ação legislativa, ação executiva e ação judicante." 9

Destaca-se, ainda, a importante distinção existente entre as funções ditas permanentes da Administração e, de outro lado, as transitórias. O esclarecimento deste tema trará subsídio suficiente para que mais adiante se possa compreender o tema da continuidade, no que toca aos seus agentes e a forma de preenchimento dos cargos, com vistas à garantia da continuidade da função estatal. As funções chamadas de permanentes da Administração, por sua natureza, só podem ser desempenhadas pelos titulares de cargos efetivos.

\footnotetext{
${ }^{8}$ MOREIRA NETO, Diogo de Figueiredo. Curso de Direito Administrativo. 14. ${ }^{\text {a }}$ ed. Rio de Janeiro: Forense, 2005, p. 288 (grifos do original).

${ }^{9}$ SCARTEZZINI, Ana Maria Goffi Flaquer. O princípio da continuidade do serviço público. São Paulo: Malheiros Editores, 2006, p. 42.
} 
Diferentemente, as funções transitórias podem ser desenvolvidas por servidores designados, admitidos ou contratados precariamente.

Apura-se com facilidade, pois, a ideia de que todo cargo é composto de funções, mas nem toda função corresponde a um cargo. A definição de função, nas palavras de Hely Lopes Meirelles, é: "a atribuição ou o conjunto de atribuições que a Administração confere a cada categoria profissional ou comete individualmente a determinados servidores para a execução de serviços eventuais". ${ }^{10}$ Daí por que as funções autônomas, assim entendidas como aquelas não vinculadas a um cargo público efetivo, são transitórias, a exemplo do disposto no art. 37, IX, $\mathrm{CF}^{11}$ ou de funções daqueles que exercem múnus público, como mesários e jurados. De outra sorte, as funções permanentes são sempre vinculadas a um cargo público efetivo. ${ }^{12}$

\subsection{Serviços públicos}

Ainda no âmbito dos conceitos preliminares, fundamentais à perfeita compreensão do tema, este item destina-se a (tentar) delimitar o campo de incidência deste estudo. Para tanto, procura-se delinear o que se entende por serviço público a fim de que se possa, mais adiante, determinar quais os serviços submetidos ao princípio da continuidade.

\footnotetext{
${ }^{10}$ MEIRELLES, Hely Lopes. Direito Administrativo Brasileiro. 29. a ed. São Paulo: Malheiros Editores, 2004, p. 397.

11 “Art. 37 (...): Inc. IX - a lei estabelecerá os casos de contratação por tempo determinado para atender a necessidade temporária de excepcional interesse público." (sem itálicos no original).

${ }^{12}$ Nas palavras de Hely Lopes Meirelles: "Todo cargo tem função, mas pode haver função sem cargo. As funções do cargo são definitivas; as funções autônomas são, por índole, provisórias, dada a transitoriedade do serviço que viam a atender, como ocorre nos casos de contratação por prazo determinado (CF, art. 37, IX). Daí porque as funções permanentes da Administração só podem ser desempenhadas pelos titulares de cargos efetivos, e as transitórias, por servidores designados, admitidos ou contratados precariamente" (Ibidem, p. 397).
} 
Destarte, pode-se dizer que o serviço público é aquele proveniente da atuação do Estado. A importância de se delimitar o conceito de serviço público está, por certo, na inafastável necessidade de determinar-se, com alguma precisão, a separação entre direito público e privado. ${ }^{13}$

A ideia há muito assentada de que o Estado é o responsável pela concretização do bem-estar social fez com que ele reservasse para si a prestação dos serviços havidos por 'essenciais' para os administrados. E assim o fez - e faz - justamente por considerar que determinadas atividades não podem, pura e simplesmente, ficar "relegadas à livre iniciativa."14 Nas palavras de Celso Antônio Bandeira de Mello, tais atividades, o Estado assume como próprias “ $a$ fim de satisfazer necessidades ou comodidades do todo social, reputadas como fundamentais em dado tempo e lugar."15

Enquanto a função pública tem significado mais abrangente, porque representa a atividade dirigida à realização dos fins havidos como essenciais pelo Estado em uma perspectiva fundamentalmente coletiva, os

\footnotetext{
${ }^{13}$ Conforme já anotamos e como mais adiante ficará evidente, essa 'separação' - estanque e muito bem delimitada - tem passado por significativas mutações, mutações essas com impacto direto na compreensão do conceito e perfil dos serviços públicos. Inteiramente válida a transcrição das lições de Odete Medauar, quanto a uma suposta 'crise' dos serviços públicos na atualidade: "Tendo em vista que a Escola de Serviço Público concebia o serviço público como atividade prestada pelo poder público, registrou-se verdadeiro abalo nessa teoria quando se expandiu a execução de serviços públicos por particulares; falou-se, então, de crise da noção de serviço público, que nada mais era do que inadequação de uma teoria específica à extensão das prestações estatais, hoje realizadas sob modos variados. A atividade de prestação de serviços públicos não se encontra em crise, nem desapareceu; ao contrário, hoje se reveste de grande importância, sobretudo porque impõem ao poder público uma exigência de atendimento das necessidades básicas da vida social, ligadas, inclusive, a direitos sociais assegurados na Constituição." (MEDAUAR, Odete. Direito Administrativo Moderno. 11. ${ }^{\mathrm{a}}$ ed. rev., atual. e ampl. São Paulo: Revista dos Tribunais, 2007, p. 314). Em artigo escrito sobre o tema, a professora conclui, dizendo: "A concepção clássica pode não vigorar hoje nos seus exatos termos. Aliás, deve-se lembrar que em sua noção Duguit não associou serviço público a gestão estatal. O serviço público muda sua conformação segundo as transformações da sociedade, da tecnologia e da política." (MEDAUAR, Odete. Serviços públicos e serviços de interesse geral. Uma avaliação das tendências contemporâneas do Direito Administrativo - Anais do Seminário de Direito Administrativo Brasil - Espanha. Coord. Diogo de Figueiredo Moreira Neto. Rio de Janeiro: Renovar, 2003, p. 126).

${ }^{14}$ MELLO, Celso Antônio Bandeira de. Curso de Direito Administrativo. 27. a ed. São Paulo: Malheiros Editores, 2010, p. 661.

${ }^{15}$ Ibidem, mesma página.
} 
serviços públicos - ainda que, naturalmente, procurem alcançar o bem estar da coletividade - o fazem atendendo às necessidades individuais dos $\operatorname{administrativos}^{16}$, donde se verifica que função é mais que serviço público.

A dificuldade no trato do tema assenta suas raízes na polêmica existente em torno do conceito de serviço público, cujas definições oferecidas na doutrina são deveras díspares. ${ }^{17-18}$ Assim como dentre os primeiros doutrinadores franceses, ainda hoje na doutrina a expressão ora é utilizada em sua acepção ampla (açambarcando as funções do Judiciário e também do Legislativo), ora em seu significado mais estrito.

A ambiguidade no uso da expressão serviço público é igualmente sentida no espectro do direito estrangeiro, como aponta Marcello Caetano. ${ }^{19}$

Registre-se, porém, que a merecida atenção ao tema serviço público, segundo a melhor doutrina, resultou de uma exigência da realidade. Assim, aponta-se a sua gênese na jurisprudência francesa, que se deparou com a necessidade de delimitar as esferas de competência em casos envolvendo ações de responsabilidade contra o Estado. O caso mais famoso ocorreu na cidade de

\footnotetext{
${ }^{16} \mathrm{Ou}$, como prefere Marcello Caetano, "O serviço público propõe-se satisfazer uma necessidade coletiva individualmente sentida." (CAETANO, Marcello. Manual de Direito Administrativo. 10. ${ }^{a}$ ed., 6. ${ }^{a}$ reimp. Porto: Almedina, Tomo II, 1999, p. 1.067 - destaques nossos).

${ }^{17}$ Sensível a este fato, Caio Tácito anotara: "A noção [de serviço público] é fugidia e variável, assemelhando-se, na disparidade de critérios e definições, a um diálogo de surdos, em que não se entendem os interlocutores, conforme a sátira de Marcel Waline (Droit administratif, 8. ${ }^{a}$ ed., 1959, pág. 620)." (TÁCITO, Caio. Direito Administrativo. São Paulo: Saraiva, 1975, p. 188). Este mesmo autor, referindo-se a trabalho específico sobre o tema, adverte para ponto que, em nosso sentir (e especialmente nos dias atuais), tem toda a razão de ser: "Observei, em trabalho anterior, que não há um conceito apriorístico de serviço publico, elastecendo-se o seu âmbito na medida em que se expande a presença do Estado nos domínios da vida social contemporânea." (Ibidem, p. 198).

${ }^{18}$ Atribui-se a Rousseau - ainda que destituída do significado atual - a utilização originária da expressão pela primeira vez, segundo anota Dinorá Adelaide Mussetti Grotti (GROTT, Dinorá Adelaide Mussetti. O Serviço Público e a Constituição Brasileira de 1988. São Paulo: Malheiros Editores, 2003, p. 20).

${ }^{19}$ Diz: "A expressão serviço público é ambígua, quer na sua doutrina, quer na prática." (Ibidem, p. 1.067 - destaques do original).
} 
Bordeaux, no século XIX (ano de 1873), e ficou conhecido como o 'caso Blanco' ${ }^{20}$

Na ocasião, o sistema judiciário Francês, dividido em duas esferas de competência - uma para julgar os casos contra o Estado (justiça administrativa) e outro, que era a justiça ‘comum' (justiça judicial) - deparou-se com uma ação movida pelo pai de uma jovem (Agnès Blanco) ferida por um pequeno vagão de uma manufatura de tabaco, integrante da Administração francesa. Pretendia, o pai da jovem, responsabilizar o Estado pelo ocorrido, vendo-se então agraciado por decisão do Tribunal de Conflitos que vinculou o tratamento diferenciado da responsabilidade do Estado ao fato da causadora do dano estar, ali, na condição de prestadora de um serviço público e, portanto, atribuiu a competência para decidir à jurisdição administrativa, e não a comum. $^{21}$

Ainda que não se possa dizer que o emprego da expressão "serviço público" pelo Conselho de Estado Francês coincida com o que, tecnicamente, utiliza-se na atualidade, é reconhecido o fato de ter sido o caso Blanco - conquanto não o único e nem mesmo o primeiro ${ }^{22}$ a utilizar a expressão 'serviço público' e, assim, responsabilizar o Estado por atos de agentes que a França empregava no serviço público - o que mais repercutiu, em todo o mundo, contribuindo na construção da teoria do serviço público. ${ }^{23}$

\footnotetext{
${ }^{20}$ MEDAUAR, Odete. Serviço Público. Revista de Direito Administrativo. Rio de Janeiro, v. 189, jul./set. 1992, p. 102.

${ }^{21}$ Ibidem, mesma mágina.

${ }^{22}$ Odete Medauar relata: "No entanto, outras decisões anteriores proclamavam, com nitidez, o sentido do serviço público. Assim, o arrêt Rothschild, CE, 1855. Os fatos foram os seguintes: uma carta do Sr. Rothschild, remetida de Londres para a posta restante de Paris, e na qual havia diamantes de valor, foi perdida por culpa de agente desta que a tinha remetido a outro Rothschild, A decisão menciona serviços públicos. No mesmo sentido as decisões: Carcassone, de 1858 (perda de carta); Baudry, de 1861 (ferimentos causados em cavalo, atrelado a charrete, que foi derrubada por carro de equipamentos militares); Dekeister, 1862 (perda de carta com valores). Todas são ações contra o Estado, em virtude de danos advindos dos serviços públicos. Em todas se afirma que a Administração é regida por direito especial quando desempenha serviços públicos." (Ibidem, mesma página - os grifos são do original).

23 A repercussão do "caso Blanco", segundo Odete Medauar, deve-se a dois fatores fundamentais: "a) foi emitida após o Conselho de Estado tornar-se jurisdição independente, com
} 
Neste trabalho, onde não cabe o estudo de todas as escolas que se debruçaram em torno da compreensão e significado de serviço público ${ }^{24}$, adotaremos o conceito proposto por Odete Medauar, compreendendo o serviço público em seu sentido mais estrito, ou seja, como integrante do direito administrativo, representativo da "atividade [prestacional] realizada no âmbito das atribuições da Administração, inserida no Executivo", e por meio da qual o Poder Público "propicia algo necessário à vida coletiva, como, por exemplo, água, energia elétrica, transporte urbano". ${ }^{25}$

Prossegue a autora, dizendo que:

Em essência, serviço público significa prestações; são atividades que propiciam diretamente benefícios e bens, aos administrados, não se incluindo aí as de preparação de infra-estrutura (arquivo, arrecadação de tributos). Abrange prestações específicas para determinados indivíduos - água, telefone - e prestações genéricas - iluminação pública, limpeza de ruas. ${ }^{26}$

E justamente em razão dessa peculiar natureza, tais atividades se subordinam a uma disciplina específica ${ }^{27}$, ou, como se anota no seio da doutrina,

justiça delegada (1872); b) não mais aparece na considerada invocação do decreto de 26 de setembro de 1793, que atribuía somente à autoridade administrativa a decisão de pedidos que tendiam a fazer do Estado um devedor. O arrêt Blanco deixou de se referir a esse decreto, para fixar a competência da justiça administrativa, e vinculou essa competência à atuação do Estado na prestação de serviços públicos. O comissário de governo David ligou serviço público a direito público." (MEDAUAR, Odete. Serviço Público. Revista de Direito Administrativo, Rio de Janeiro, v. 189, jul./set. 1992, p. 102 - itálicos do original).

${ }^{24}$ Para uma visão das principais escolas francesas, notadamente a Escola do Serviço Público ou Escola de Bordeaux, capitaneada por Lèon Duguit e Jèze, nas primeiras décadas do séc. XX, consulte-se MEDAUAR, Odete. Serviços públicos e serviços de interesse geral. In: MOREIRA NETO, Diogo de Figueiredo (Coord). Uma avaliação das tendências contemporâneas do Direito Administrativo - Anais do Seminário de Direito Administrativo Brasil - Espanha. Rio de Janeiro: Renovar, 2003, especialmente pp. 116-118.

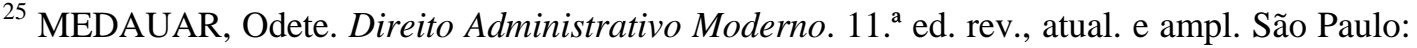
Revista dos Tribunais, 2007, p. 313.

${ }^{26}$ Ibidem, pp. 314-315.

${ }^{27}$ Disciplina essa que, no direito brasileiro, conquanto não codificada, é facilmente identificada a partir da unidade sistemática de princípios e normas "que formam em seu todo o direito administrativo", consoante afirmou Celso Antônio Bandeira de Mello (MELLO, Celso Antônio

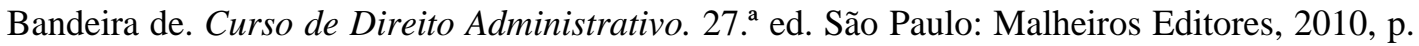


"No momento em que a atividade de prestação recebe a qualificação de serviço público, consequências advêm, em especial quanto ao regime jurídico, mesmo que fornecida por particulares." ${ }^{28}$ Este ponto foi igualmente percebido por Celso Antônio Bandeira de Mello, para quem:

preordenada a garantir proteção aos interesses coletivos nelas encarnados, de sorte a facilitar-lhes a viabilização, assim como defendêlas não apenas contra terceiros ou contra as pessoas que ele próprio haja habilitado a prestá-los, mas também contra omissões ou desvirtuamentos em que o próprio Estado possa incorrer ao propósito delas. $^{29}$

A Constituição Federal de 1988 enumera exemplificativamente alguns serviços públicos. Assim, indica no rol do art. 21 os serviços de telecomunicações (inc. XI), de radiofusão sonora e de sons e imagens (inc. XII), serviços e instalações nucleares, além de fazer referência a diversos outros serviços ao longo de seu texto (como a saúde, a segurança pública, a educação, dentre outros).

Consoante precisa sistematização proposta por Odete Medauar, elencam-se os seguintes elementos comuns às atividades qualificadas como serviços públicos. Em primeiro lugar, o que se denominada de "vínculo orgânico com a Administração", porquanto não mais se pode dizer que o serviço público seja uma atividade executada apenas por órgãos públicos. ${ }^{30} \mathrm{De}$ outro lado, no que respeita ao regime jurídico, “a atividade de prestação é submetida total ou parcialmente ao direito administrativo", ou seja, "mesmo que seja realizada por particulares, em tese sujeita a regras do direito privado, se

15). Dedicaremos maior atenção a este aspecto no capitulo seguinte (Capítulo 2, "Princípios administrativos", infra).

${ }^{28}$ MEDAUAR, Odete. Direito Administrativo Moderno. 11. ${ }^{a}$ ed. rev., atual. e ampl. São Paulo: Revista dos Tribunais, 2007, p. 314.

${ }^{29}$ MELLO, Celso Antônio Bandeira de. Curso de Direito Administrativo, 26. ${ }^{a}$ ed., São Paulo: Malheiros Editores, 2008, p. 61.

${ }^{30}$ MEDAUAR, Odete. Serviço Público. Revista de Direito Administrativo, Rio de Janeiro, v. 189, jul./set. 1992, p. 110. 
a atividade for qualificada como serviço público, tem notas de diferenciação; não há serviços públicos submetidos exclusivamente ao direito privado." 31

Consequência de relevo do reconhecimento de que uma dada atividade é serviço público, como dantes assinalado e aqui repisado, é a sua submissão a certas regras ou preceitos. Dentre tais regras, aqui se elegem três, por entendê-las como as de maior importância. A este ponto voltaremos mais adiante e em particular uma dessas regras será examinada - a do funcionamento contínuo, tema que será enfocado sob diversas nuances, em Capítulo próprio, neste trabalho (espec. Capítulo 4).

Como quer que seja, impõe-se registrar, desde logo, que a caracterização de um serviço como público o submete aos seguintes preceitos, no regime jurídico brasileiro ${ }^{32}$ :

1. Em primeiro plano, à imposição de um funcionamento equitativo, preceito este que só pode ser entendido como desdobramento do princípio da igualdade, constitucionalmente assegurado, no sentido de que há de ser assegurado a todos - indistintamente - serviço público havido por essencial, de qualidade, por preço acessível ${ }^{33}$ (e, consoante reclamos mais atuais, eficiente, como se verá logo adiante);

2. Funcionamento contínuo. Este princípio é, precisamente, o objeto deste trabalho, e por razões naturais receberá a merecida atenção ao

\footnotetext{
${ }^{31}$ MEDAUAR, Odete. Serviço Público. Revista de Direito Administrativo, Rio de Janeiro, v. 189, jul./set. 1992, pp. 110-111.

${ }^{32}$ Endossamos, no particular, a opinião de Odete Medauar, enfeixando-os debaixo de três grandes regras. Há, porém, diversidade de pensamento na doutrina, havendo quem identifique até oito (8) preceitos (ou princípios). Assim, para Diogo Moreira Neto, "o regime dos serviços públicos apresenta características funcionais próprias, que o estremam do regime comum dos serviços privados, sintetizada em oito princípios jurídicos informativos dos serviços públicos: a generalidade, a continuidade, a regularidade, a eficiência, a atualidade, a segurança, a cortesia e a modicidade, que, em conjunto, atendem ao conceito jurídico indeterminado constitucional de serviço adequado (art. 175, parágrafo único, IV, CF), tal como constante da Lei n. 8.987, de 15 de fevereiro de 1995 (art. $6^{\circ},{ }^{\circ} 1^{\circ} .^{\circ}$ ) e também expresso como direito do consumidor, na Lei n. 8.078, de 11 de setembro de 1990 (art. 6. ${ }^{\circ}$, X)." (MOREIRA NETO, Diogo de Figueiredo. Curso de Direito Administrativo. 14. a ed. Rio de Janeiro: Forense, 2005, pp. 426-427 - os grifos são do original).

${ }^{33}$ Ibidem, p. 111.
} 
longo de todo o Capítulo terceiro, com seus vários desdobramentos enfrentados no Capítulo quarto. Por ora compete-nos apenas registrar que legislação federal (Lei 8.987/95, que cuida de concessões e permissões de serviço público) "indica a continuidade e regularidade entre as condições do serviço adequa$d o " 34$. Trata-se de regra que comporta algumas limitações ou exceções (para nós, como explicaremos mais adiante, conformações ao princípio da continuidade).

3. Possibilidade de alteração no modo de execução, preceito este que tem em mira permitir adaptação que se faça necessária às novas exigências da sociedade. ${ }^{35}$

Seguindo precisa anotação de Marcello Caetano, precisamente porque destinados ao público, “os serviços públicos devem proporcionar as suas prestações, por igual, a todos os indivíduos que as solicitem.” Segundo referido autor "O princípio fundamental a observar na utilização dos serviços públicos é, pois, o da liberdade de acesso às suas prestações." 36

Classicamente a doutrina agrupa os serviços públicos em várias categorias, tendo em vista os mais diferentes critérios. Tendo em vista os limites deste trabalho, contudo, apenas duas dessas classificações serão consideradas. A primeira, que distingue os serviços públicos de competência exclusiva, os concorrentes e os passíveis de delegação; de outra, determinada a partir dos seus destinatários, que diferencia os serviços 'uti universi' ou 'gerais' (que não têm destinatários determinados) dos chamados serviços uti singuli ou individuais, (prestados a usuários individualizados).

Impende considerar também, agora sob um terceiro aspecto, que é o da essencialidade, a distinção dos serviços públicos essenciais e não

\footnotetext{
${ }^{34}$ MEDAUAR, Odete. Direito Administrativo Moderno. 11. ${ }^{a}$ ed. rev., atual. e ampl. São Paulo: Revista dos Tribunais, 2007, p. 316.

${ }^{35}$ MEDAUAR, Odete. Serviço Público. Revista de Direito Administrativo, Rio de Janeiro, v. 189, jul./set. 1992, p. 112.

${ }^{36}$ CAETANO, Marcello. Princípios fundamentais do direito administrativo. Rio de Janeiro: Forense, 1989, p. 278 (grifos no original).
} 
essenciais. A dificuldade que em um primeiro momento parece rondar fortemente essa classificação reside no fato de os serviços públicos serem, em linha de princípio, essenciais, porque necessários à sociedade. ${ }^{37}$ Mas tal dificuldade, para nós, facilmente se supera, ante a possibilidade e utilidade do critério distintivo: há os serviços cuja prestação pode ser adiada, interrompida; outros há cujo atendimento não comporta interrupção, salvo nas situações excepcionais previstas em lei e quando não se vislumbrar um interesse coletivo apto a justificar a sua manutenção. ${ }^{38}$

Neste trabalho, assumiremos os primeiros como os serviços não essenciais, e os segundos, como essenciais, os quais, a seu turno, se desdobrarão em mais uma divisão, na qual se encartam os serviços de essencialidade extrema (esses, insuscetíveis de serem interrompidos, como se verá oportunamente, no Capítulo 4).

Em passagem que merece ser aqui referida ante sua inocultável clareza, Diógenes Gasparini elucida:

Quanto à essencialidade, podem ser: essenciais e não essenciais. São essenciais os assim considerados por lei ou os que pela própria natureza são tidos como de necessidade pública, e, em princípio, de execução privativa da Administração Pública. São exemplos os serviços de segurança nacional, de segurança pública e os judiciários. (...) São não essenciais os assim considerados por lei ou os que, pela própria natureza, são havidos de utilidade pública, cuja execução é facultada aos particulares. (...) Os essenciais, em princípio, não podem ser executados por terceiros. O mesmo não ocorre com os não

\footnotetext{
${ }^{37}$ Essa dificuldade foi anotada com propriedade por JUSTEN FILHO, Marçal. Curso de Direito

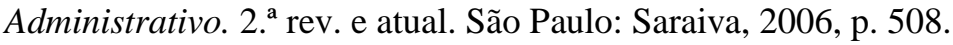

${ }^{38}$ De maneira semelhante, aduz Rizzato Nunes, antecipando preocupação sobre a qual nos debruçaremos mais adiante: "Há no serviço considerado essencial um aspecto real e concreto de urgência, isto é, necessidade concreta e efetiva de sua prestação. O serviço de fornecimento de água para uma residência não habitada não se reveste dessa urgência. Contudo, o fornecimento de água para uma família é essencial e absolutamente urgente, uma vez que as pessoas precisam de água para sobreviver. Essa é a preocupação da norma" (NUNES, Rizzatto. Comentários ao Código de Defesa do Consumidor. 2. ${ }^{\text {a }}$ ed. reform. São Paulo: Saraiva, 2005, p. 309).
} 
essenciais, cuja execução não só pode como, em alguns casos, é até permitida e desejada. ${ }^{39}$

Os serviços públicos essenciais são, enfim, aqueles "que não podem faltar", como em irretocável lição referido professor anotou. ${ }^{40}$

Na jurisprudência colhem-se, à exaustão, exemplos significativos de serviços públicos havidos por essenciais. Dentre as hipóteses mais recorrentes, estão: fornecimento de energia elétrica ${ }^{41}$; fornecimento de serviços de telefonia ${ }^{42}$; tratamento e abastecimento de água ${ }^{43}$ e também de serviços de saúde, tais como o hospitalar. ${ }^{44}$ Além disso, como se verá mais de espaço a

${ }^{39}$ GASPARINI, Diógenes. Direito Administrativo. 11. a ed. São Paulo: Saraiva, 2006, p. 294.

${ }^{40}$ Ibidem, mesma página.

${ }^{41}$ Veja-se, por exemplo: BRASIL. Tribunal de Justiça do Estado de São Paulo: AI n. ${ }^{\circ}$ 990.10.412679-7 - Mirassol. 17. a Câm. Dir. Privado. Rel. Des. Tersio Negrato. julg. 17/10/2010 e Ap. n. ${ }^{o}$ 991.07.057840-1 - Taubaté. 20. ${ }^{a}$ Câm. Dir. Privado. Rel. Des. Francisco Giaquinto. julg. 22/11/2010, onde o serviço de energia elétrica foi reconhecido como essencial (Disponível na internet em: http://www.tj.sp.gov.br. Acesso em: 02/02/2011). O Superior Tribunal de Justiça manifestou-se sobre o tema em diversas ocasiões. Em uma delas, pontuou, tratando especificamente do serviço de iluminação pública: "Não é possível a suspensão do serviço público no caso dos autos, pois as concessionárias somente podem deixar de fornecer energia elétrica a entes públicos inadimplentes quando não há prejuízo à continuidade dos serviços públicos essenciais, entre os quais a iluminação pública. 3. Agravo regimental não provido." (BRASIL. Superior Tribunal de Justiça. EDcl no Ag. n. ${ }^{\circ}$ 1242016/SP. Segunda Turma - Rel. Min. Mauro Campbell Marques. Julg. 21/09/2010. Disponível na internet em: http://www.stj.jus.br. Acesso em: 20/01/2011).

${ }^{42}$ Reconhecendo ter havido, no caso, privação "de serviço público essencial cada vez mais importante na vida social" (referindo-se à telefonia): BRASIL. Tribunal de Justiça do Estado de São Paulo. Ap. n. ${ }^{\circ}$ 990.10.452702-3. 36. ${ }^{\text {a }}$ Câm. Dir. Privado. Rel. Des. Dyrceu Cintra. v.u. julgamento em 02/12/2010. Disponível na internet em: http://www.tj.sp.gov.br. Acesso em: 20/01/2011.

${ }^{43}$ Veja-se, dentre muitos outros: BRASIL. Superior Tribunal de Justiça. AgRg nos EREsp 1003667/RS, Primeira Seção - Rel. Min. Luiz Fux, julg. em 25/08/2010 e AgRg no REsp 1201283/RJ Segunda Turma - Rel. Min. Humberto Martins, julg. em 16/09/2010 (Disponível na internet em: http://www.stj.jus.br. Acesso em: 02/02/2011). O STF tratou igualmente da questão, reconhecendo a essencialidade do serviço de fornecimento da água, ao decidir sobre a ilegitimidade de tributação (no caso, ICMS) sobre o fornecimento de água canalizada, "uma vez que se trata de serviço público essencial e não de mercadoria". (BRASIL. Supremo Tribunal Federal. RE 552948 AgR/RJ. Primeira Turma. Rel. Min. Ricardo Lewandowski. Julg. em 01/06/2010. Disponível na internet em: http://www.tj.sp.gov.br. Acesso em: 02/02/2011).

44 “(...). III - O serviço público de saúde é essencial, jamais pode-se caracterizar como temporário, razão pela qual não assiste razão à Administração estadual capixaba ao contratar temporariamente servidores para exercer tais funções. (...)" (BRASIL. Supremo Tribunal Federal. ADI 3430/ES. Tribunal Pleno. Rel. Min. Ricardo Lewandowski. Julgamento em 
seguir, vale mencionar o rol trazido pela Lei 7.783/89, única enunciação conhecida em nosso ordenamento jurídico de serviços ou atividades essenciais. $^{45}$

A este ponto dedicaremos atenção particular no Capítulo 4, infra, momento de reflexão profunda em torno dos desdobramentos e efeitos da aplicação do princípio da continuidade no âmbito dos contratos de concessão da Administração Pública e do regime de seus servidores.

\subsection{Prestação dos Serviços Públicos}

Consoante fixado linhas atrás, desde há algumas décadas o Estado e a própria Administração têm passado por sensível redimensionamento. A fim de fazer frente a essa necessidade crescente, surge o fenômeno conhecido por descentralização. Por intermédio dessa figura, permite-se que os serviços públicos - inicialmente prestados exclusiva e diretamente pela Administração direta - sejam prestados, por outorga, a entidades da Administração Indireta ou entidades análogas, ou, por particulares, por delegação. ${ }^{46}$

12/08/2009. Disponível na internet em: http://www.stf.jus.br. Acesso em: 02.12.2010 - grifos nossos).

45 In verbis: "Art. 10 São considerados serviços ou atividades essenciais: I - tratamento e abastecimento de água; produção e distribuição de energia elétrica, gás e combustíveis; II assistência médica e hospitalar; III - distribuição e comercialização de medicamentos e alimentos; IV - funerários; V - transporte coletivo; VI - captação e tratamento de esgoto e lixo; VII - telecomunicações; VIII - guarda, uso e controle de substâncias radioativas, equipamentos e materiais nucleares; IX - processamento de dados ligados a serviços essenciais; $\mathrm{X}$ - controle de tráfego aéreo; XI - compensação bancária."

${ }^{46} \mathrm{Ou}$, ainda, atribuídas a pessoas jurídicas públicas mediante a figura do convênio, ou até mesmo por intermédio de novas modalidades, tal como examinado ulteriormente. Para um exame do assunto, v. MEDAUAR, Odete. O Direito Administrativo em Evolução. 2. ${ }^{\mathrm{a}}$ ed. rev. atual. e ampl. São Paulo: Revista dos Tribunais, 2003, pp. 248-ss. 
Cumprindo este papel, a Constituição de 1988 concebeu a Administração distribuída em vários segmentos: a Administração Direta, a Administração Indireta e, ademais, mecanismos de parcerias com os particulares. Com efeito, atribui o art. 175 da CF o serviço público ao Poder Público, de maneira direta, mas não apenas, prevendo ainda a possibilidade de sua execução mediante concessão, autorização ou permissão. ${ }^{47}$

Em função disso é acertado dizer que os serviços públicos podem ser prestados pela Administração Direta (ocasião em que o fazem por seus servidores) ou, ainda, executados por particulares, situação essa denominada de descentralização, consoante frisado.

O enfrentamento de cada uma dessas figuras, com a profundidade desejada, excede os limites deste capítulo, desenhado exclusivamente com o intuito de fornecer as premissas necessárias para situar a imprescindibilidade de continuidade de um dado serviço ao usuário. Para tanto, abordaremos os temas unicamente com esse propósito: não de aprofundar nem solucionar todas as questões que os cercam, mas de apenas oferecer premissas ao objeto central deste trabalho.

Iniciemos o exame das categorias compreendidas no âmbito da Administração Indireta, ainda que bastante breve, pelo da concessão. Dando cumprimento ao disposto no parágrafo único do art. 175, Constituição Federal ${ }^{48}$, a União editou a Lei 8.987, de 13/02/1995, a qual regulamenta e disciplina o

\footnotetext{
${ }^{47}$ As figuras da concessão, da permissão e da autorização não esgotam as hipóteses de descentralização, como se anotou na precedente nota de rodapé. Há outras. Pode-se pensar na figura dos consórcios públicos (Lei 11.107) e nas parcerias público-privadas (Lei 11.079) e, mais modernamente, até o arrendamento e a franquia. Mas, tendo em vista que o estudo destes temas não é o ponto central deste trabalho, ao contrário, sua análise é feita tão somente com a finalidade de se estabelecerem as premissas para o estudo do objeto central, a limitação em seu exame é providência que se impõe.

${ }^{48}$ Ipsis verbis: "Art. 175. Incumbe ao Poder Público, na forma da lei, diretamente ou sob regime de concessão ou permissão, sempre através de licitação, a prestação de serviços públicos."

Parágrafo único - A lei disporá sobre: I - o regime das empresas concessionárias e permissionárias de serviços públicos, o caráter especial de seu contrato e de sua prorrogação, bem como as condições de caducidade, fiscalização e rescisão da concessão ou permissão; II os direitos dos usuários; III - política tarifária; IV - a obrigação de manter serviço adequado."
} 
regime jurídico para as concessões e permissões para a execução do serviço público. $^{49}$

A expressão concessão é, a exemplo de outros institutos pertencentes ao direito administrativo, polissêmica. Em seu sentido mais abrangente, é empregada para expressar todo e qualquer tipo de transferência de titularidade na execução de serviços públicos.

Mas, nos termos da Lei 8.987, a concessão há de ser compreendida como "a delegação contratual da execução do serviço, na forma autorizada e regulamentada pelo Executivo." ${ }^{\circ 0}$ Como resulta claro dos termos legais, trata-se de contrato de direito administrativo, bilateral, oneroso, comutativo e realizado, como regra, intuitu personae. ${ }^{51}$

Por isso se aduz ser "um acordo administrativo (e não um ato unilateral da Administração), com vantagens e encargos recíprocos, no qual se fixam as condições de prestação do serviço, levando-se em consideração o interesse coletivo na sua obtenção e as condições pessoais de quem se propõe a executá-lo por delegação do poder concedente." 52 Como não poderia deixar de ser, porque é um contrato administrativo, subordina-se a todos os preceitos da Administração fundamentais à consagração do acordo (e, assim, necessita de autorização governamental, de regulamentação e, por igualmente, sujeita-se ao procedimento licitatório).

Para Marcello Caetano, a concessão significa o emprego do "estímulo da iniciativa privada e da sua flexibilidade e experiência para proveito

\footnotetext{
${ }^{49}$ A Lei 8.987 foi modificada pela Lei n. ${ }^{\circ} 9.074$ (esta destinada a regulamentar as concessões e permissões dos serviços de energia elétrica).

${ }^{50}$ MEIRELLES, Hely Lopes. Direito Administrativo Brasileiro. 29. a ed. São Paulo: Malheiros Editores, 2004, pp. 367-368.

${ }^{51}$ Cf. art. 25 da Lei 8.987. Mas o dispositivo seguinte deste mesmo diploma legal - art. 26 admite a subconcessão, desde que precedida de concorrência.

${ }^{52}$ Ibidem, mesmas páginas.
} 
do interesse público", observação que nos parece pertinente e salutar de ser feita. $^{53}$

Por intermédio da concessão o poder concedente não transfere propriedade alguma ao concessionário, nem tampouco se libera de qualquer direito ou prerrogativa pública. Há, pura e simplesmente, a delegação da ехесис̧ão do serviço, o que há de ser feito sempre nos limites e previsões legais ou contratuais. ${ }^{54-55}$

Em sentido análogo, destaca Ana Maria Goffi Flaquer Sacartezzini: "para o Estado, a transferência da execução da atividade, cuja titularidade mantém, não significa abrir mão da competência para o serviço, de modo a torná-lo submisso às regras do mercado; remanesce ínsita a posição de supremacia indispensável para a persecução do interesse público primário.",56

Em trecho bastante didático de acórdão da lavra do Ministro Luiz Fux, o Superior Tribunal de Justiça registrou a ser (...) “a concessão de serviço público é o instituto através do qual o Estado atribui o exercício de um serviço público a alguém que aceita prestá-lo em nome próprio, por sua conta e risco, nas condições fixadas e alteráveis unilateralmente pelo Poder Público, mas sob garantia contratual de um equilíbrio econômico-financeiro, remunerando-se pela

\footnotetext{
${ }^{53}$ CAetano, Marcello. Princípios fundamentais do direito administrativo. Rio de Janeiro: Forense, 1989, p. 296.

${ }^{54}$ MEIRELLES, Hely Lopes. Direito Administrativo Brasileiro. 29. a ed. São Paulo: Malheiros Editores, 2004, p. 368.

${ }^{55}$ A respeito, afirma Odete Medauar: "Conforme o art. $2{ }^{\circ}$, II, da Lei 8.987/95, concessão de serviço público é a transferência da prestação de serviço público, feita pela União, Estados, Distrito Federal e Municípios, mediante concorrência, a pessoa jurídica ou consórcio de empresas que demonstre capacidade para seu desempenho, por sua conta e risco e por prazo determinado." (MEDAUAR, Odete. Direito Administrativo Moderno. 11. ${ }^{\mathrm{a}}$ ed. rev., atual. e ampl. São Paulo: Revista dos Tribunais, 2007, p. 320).

${ }^{56}$ SCARTEZZINI, Ana Maria Goffi Flaquer. O princípio da continuidade do serviço público. São Paulo: Malheiros Editores, 2006, p. 66.
} 
própria exploração do serviço, e geral e basicamente mediante tarifas cobradas diretamente dos usuários do serviço." 57

Com contornos diversos, surgem as figuras da permissão e da autorização. Ainda que ambas, à semelhança da concessão, representem transferência de exercício ao particular da prestação de um dado serviço público, diferenciam-se substancialmente daquela. ${ }^{58}$

Permissão, nos dizeres de Hely Lopes Meirelles, "é o ato administrativo negocial, discricionário e precário, pelo qual o Poder Público faculta ao particular a execução de serviços de interesse coletivo, ou o uso especial de bens públicos, a título gratuito ou remunerado, nas condições estabelecidas pela Administração. Não se confunde com a concessão, nem com a autorização: a concessão é contrato administrativo bilateral; a autorização é ato administrativo unilateral. Pela concessão contrata-se um serviço de utilidade pública; pela autorização consente-se numa atividade ou situação de interesse exclusivo ou predominante do particular; pela permissão faculta-se a realização de uma atividade de interesse concorrente do permitente, do permissionário e do público.",59-60-61

\footnotetext{
${ }^{57}$ BRASIL. Superior Tribunal de Justiça. REsp n. ${ }^{\circ}$ 976836/RS. Primeira Seção. Rel. Min. Luiz Fux. Julgamento em 25/08/2010. Disponível na internet em: http://www.stj.jus.br. Acesso em: 02/12/2010.

${ }^{58}$ Ainda que o próprio constituinte tenha assimilado, em certa medida, a figura da permissão à concessão (vide o art. 175, parágrafo único, I, CF).

${ }^{59}$ MEIRELLES, Hely Lopes. Direito Administrativo Brasileiro. 29. a ed. São Paulo: Malheiros Editores, 2004, pp. 186-187.

${ }^{60}$ Ibidem, p. 383.

${ }^{61}$ A respeito do tema, aduz Diogo de F. Moreira Neto: "O regime permissional, menos rígido, tem sido caracterizado na doutrina tradicional como vínculo produzido por simples manifestação de vontade unilateral da Administração, através de um ato administrativo, discricionário e precário, que seria, por isso, revogável a qualquer tempo. Com a Constituição de 1988, o direito positivo desligou-se da tradição doutrinária e assimilou a permissão de serviços públicos à concessão (art. 175, parágrafo único, I, CF), mantendo-se, todavia, intacta a permissão, como ato unilateral hábil para instrumentar a transferência precária da utilização de bens públicos. Não se confunda, todavia, permissão com autorização; enquanto esta é outorgada para fazer predominante interesse do particular, a permissão pressupõe o atendimento conto e simultâneo do interesse privado e do interesse público a cargo do Permitente." (MOREIRA NETO, Diogo de Figueiredo. Curso de Direito Administrativo. 14. ${ }^{a}$ ed. Rio de Janeiro: Forense, 2005, p. 271).
} 
Conclui-se, pois, em face da normatização proposta pela Lei 8.987/95, que a diferença entre concessão e permissão de serviço público situase, fundamentalmente, em dois pontos: a) a concessão é atribuída a pessoa jurídica ou consórcio de empresas, enquanto a permissão é atribuída a pessoa física ou jurídica; b) a concessão destinar-se-ia a serviços de longa duração, "inclusive para propiciar retorno de altos investimentos da concessionária; a permissão supõe média ou curta duração."62

A figura da autorização, por fim, não recebeu a mesma preocupação do legislador, não tendo sido disciplinada pela Lei de Concessões e Permissões (Lei 8.987/95). E assim se fez pela sua menor rigidez, e evidente maior informalidade, dispensando inclusive o procedimento licitatório prévio, exigido para a concessão e para a permissão.

A formalização da autorização ocorre por ato administrativo unilateral, precário e discricionário. Consoante Odete Medauar, "Em geral, pela autorização se transferem ao particular serviços de fácil execução, de regra sem remuneração por tarifas; é o caso da autorização para conservação de praças, jardins ou canteiros de avenidas, em troca da afixação de placa com o nome da empresa." 63

$\mathrm{Na}$ autorização, leciona Hely Lopes Meirelles, conquanto o interessado (pretendente) satisfaça, em linha de princípio, as exigências administrativas, competirá ao Poder Público decidir com base na

${ }^{62} \mathrm{O}$ mesmo professor adverte, porém, ser permissão, em princípio, discricionária e precária. "Em princípio", registra Hely Lopes Meirelles, e prossegue: "mas [a permissão] admite condições e prazos para exploração do serviço, a fim de garantir rentabilidade e assegurar a recuperação do investimento do permissionário visando a atrair a iniciativa privada. O que se afirma é que a unilateralidade, a discricionariedade e a precariedade são atributos da permissão, embora possam ser excepcionados em certos casos, diante do interesse administrativo ocorrente. Esses condicionamentos e adequações do instituto para delegação de serviços de utilidade pública ao particular - empresa ou pessoa física - não invalidam a faculdade de o Poder Público, unilateralmente e a qualquer momento, modificar as condições iniciais do termo ou, mesmo, revogar a permissão sem possibilidade de oposição do permissionário, salvo se ocorrer abuso de poder ou desvio de finalidade da Administração ou se tratar de permissão condicionada, caso em que as condições e prazos devem ser respeitados pela Administração que os instituiu." (MEIRELLES, Hely Lopes. Direito Administrativo Brasileiro. 29. ${ }^{a}$ ed. São Paulo: Malheiros Editores, 2004, p. 383).

${ }^{63}$ MEDAUAR, Odete. Direito Administrativo Moderno. 11. ${ }^{\mathrm{a}}$ ed.. rev., atual. e ampl. São Paulo Revista dos Tribunais, 2007, p. 327. 
discricionariedade acerca da "conveniência ou não do atendimento da pretensão do interessado ou da cessação do ato autorizado, diversamente do que ocorre com a licença e a admissão, em que, satisfeitas as prescrições legais, fica a Administração obrigada a licenciar ou a admitir.",64

Celso Antônio Bandeira de Mello suscita importante dúvida quanto ao emprego da expressão autorização pelo texto constitucional (vide, em particular, o art. 21, incisos XI e XII, CF), o que teria gerado grande confusão no seio da doutrina, que entende ter havido equiparação entre as fórmulas (concessão, permissão e autorização).

Endossamos irrestritamente a lição de aludido professor, elucidando a questão. Para ele, uma leitura destes preceitos permite-nos concluir que o art. 175/CF é o dispositivo que trata da "normalidade da prestação de serviços públicos por sujeitos titulados pelo Estado." 65

Em sintética conclusão, temos que a 'autorização' do art. 21, incisos XI e XII, referem-se a duas hipóteses: na primeira, a situações em que o serviço de telecomunicações não tem natureza de serviço público, mas de serviço de interesse privado (e.g., os serviços de radioamador ou de interligação de empresas por cabos de fibras óticas). A outra diz respeito a situações em que efetivamente está em questão um serviço público, mas atendendo a situações excepcionais e emergenciais, até que se possa promover o procedimento adequado. $^{66}$

As figuras de delegação até aqui examinadas não esgotam as fórmulas de transferência de execução de serviços públicos passíveis de serem

\footnotetext{
${ }^{64}$ MEIRELLES, Hely Lopes. Direito Administrativo Brasileiro. 29. a ed. São Paulo: Malheiros Editores, 2004, p. 186.

${ }^{65}$ MELLO, Celso Antônio Bandeira. Curso de Direito Administrativo. 27. a ed. São Paulo: Malheiros Editores, 2010, pp. 690-691.

${ }^{66}$ Ibidem, p. 691.
} 
utilizadas pela Administração Pública. ${ }^{67}$ Em sua concepção atual, o Estado tem adotado diversificadas estruturas, como se dá, por exemplo, na regulação (agências reguladoras), nas parcerias público-privadas e nos convênios. ${ }^{68}$

As agências reguladoras são autarquias de regime especial, com funções de regular a matéria específica que lhe é submetida. Maria Sylvia Zanella Di Pietro consigna a existência, no direito brasileiro, de dois tipos de agências reguladoras: de um lado, aquelas que "exercem poder de polícia, com base em lei, com a imposição de limitações administrativas, fiscalização e repressão", categoria que engloba, por exemplo, a ANVISA - Agência Nacional de Vigilância Sanitária e a ANS - Agência Nacional de Saúde; de outro, a seu turno, estão "as que regulam e controlam as atividades que constituem objeto de concessão, permissão ou autorização de serviço público (telecomunicações, transportes, energia elétrica etc.), ou de concessão para exploração de bem público (petróleo e outras riquezas minerais, rodovias etc.)."69

A essas entidades, o Poder Público delega, portanto, as funções de fiscalizar, aplicar sanções, regular e controlar determinado serviço ou segmento público, com o fim de melhor prover os serviços públicos, em sentido amplo.

Figura mais recente em nosso sistema, a parceria público-privada trazida pela Lei 11.079/2004, consubstancia, nos dizeres de Diógenes Gasparini,

\footnotetext{
${ }^{67}$ Diogo de Figueiredo Moreira Neto adverte: "Desde logo, esclareça-se que o preceito constitucional, do art. 175, caput, que trata exclusivamente do regime de delegação contratual de serviços públicos, não deve ser tomado como excludente de outros regimes constitucionalmente possíveis para instrumentar uma delegação." (MOREIRA NETO, Diogo de Figueiredo. Curso de Direito Administrativo. 14. ${ }^{a}$ ed. Rio de Janeiro: Forense, 2005, p. 274).

${ }^{68}$ Este fenômeno não se restringe ao Brasil. Na Espanha - assim como em vários lugares de todo o mundo - a doutrina idêntica há tempos movimentos análogos, sobretudo a figura da privatização. Francisco José Villar Rojas, assim, aduz: "La privatización es una de las manifestaciones más significativas del debate sobre el equilibrio ente lo público y lo privado (...)”. (ROJAS, Francisco José Villar. Privatización de servicios públicos. Madrid: Tecnos, 1993, p. 23). Ver, sobre o tema privatização, a obra de Marcos João Teixeira do Amaral Filho, onde realiza extensa análise sobre o fenômeno em nível mundial, inclusive sobre as experiências nos países Japão, França, Espanha e União Soviética (AMARAL FILHO, Marcos João Teixeira do. Privatização no Estado Contemporâneo. São Paulo: Ícone, 1996, esp. pp. 6194).

${ }^{69}$ DI PIETRO, Maria Sylvia Zanella. Direito Administrativo. 20. ${ }^{\text {a }}$ ed. São Paulo: Atlas, 2007, pp. 434-435.
} 
um contrato administrativo por prazo certo e compatível com o retorno do investimento privado, celebrado pela Administração Pública com certa entidade particular, remunerando-se o parceiro privado conforme a modalidade de parceria adotada, destinado a regular a prestação de serviços públicos ou a execução de serviços públicos precedidos de obras públicas ou, ainda, a prestação de serviços em que a Administração Pública é sua usuária direta ou indireta, respeitando sempre o risco assumido. ${ }^{70}$

Trata-se de um contrato de concessão, na modaldiade patrocinada ou administrativa, onde o a concessão de serviço ou de obra pública envolve, "adicionalmente à tarifa cobrada dos usuários, contraprestação pecuniária do parceiro público ao privado."71

Deve-se registrar, porém, que a Lei 11.079 não alterou o sentido ou o significado da expressão concessão, aqui empregada neste trabalho. Ao cuidar de duas novas modalidades de concessão (tanto a patrocinada quanto a administrativa), citada lei trouxe uma série de mecanismos (pré-contratuais e contratuais) garantidores de um ambiente de colaboração mais profícuo entre o público e o privado. Manteve-se incólume, a nosso ver, a expressão concessão como representativa de gênero acolhedor de várias espécies (e aí compreendidas as figuras já examinadas e, igualmente, as novas modalidades trazidas pela Lei $11.079) .^{72}$

Outra forma de delegação de serviços comumente utilizada pela Administração é o convênio, definida como "forma de ajuste entre o poder Público e entidades públicas ou privadas para a realização de objetivos de

\footnotetext{
${ }^{70}$ GASPARINI, Diógenes. Direito Administrativo. 11. a ed. São Paulo: Saraiva, 2006, pp. 408409.

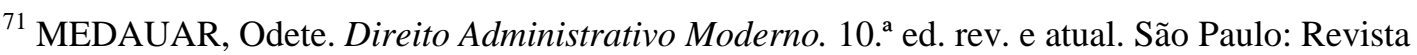
dos Tribunais, 2006, p. 328.

${ }^{72}$ Para Floriano Azevedo Marques Neto, a lei em alusão teve o condão de imprimir uma mudança no tratamento dos contratos administrativos (MARQUES NETO, Floriano Azevedo. Reajuste e revisão nas parcerias público-privadas: revisitando o risco nos contratos de delegação. In: SOUZA, Mariana Campos de (Org.). Parceria Público-privada: aspectos jurídicos relevantes: São Paulo: Quartier Latin, 2008, p. 70).
} 
interesse comum, mediante mútua colaboração."73 Nesse tipo de delegação, há o mútuo interesse, uma finalidade comum, onde um resultado único é objetivado pelas partes.

\subsection{O Estado como prestador de serviços e o Código de Proteção e Defesa do Consumidor}

De início, convém registrar que a nítida preocupação do legislador brasileiro $^{74}$ com a tutela do consumidor, e, em particular, a proteção do consumidor de serviços, é notada também no âmbito do direito estrangeiro.

A propósito, Gabriel A. Stiglitz faz apontamento similar, referindo-se ao direito argentino. ${ }^{75}$ Analogamente, a tendência a uma maior proteção dos 'usagers' de serviços públicos na França e na Comunidade Européia é confirmada por Jean Calais-Auloy e Frank Steinmetz. ${ }^{76}$

Frente a essa constatação, dedicaremos algumas linhas à viva polêmica estabelecida em torno de saber se os serviços públicos consubstanciam-se (ou se podem consubstanciar) em relações de consumo, passíveis de enquadramento nas regras do Código de Proteção e Defesa do Consumidor.

\footnotetext{
${ }^{73}$ DI PIETRO, Maria Sylvia Zanella. Direito Administrativo. 20. a ed. São Paulo: Atlas, 2007, p. 314.

${ }^{74} \mathrm{Em}$ todos os níveis: desde o legislador constituinte, que erigiu o tema a garantia constitucional, como o ordinário.

${ }^{75}$ STIGLITZ, Gabriel A.. Protección jurídica del consumidor. 2. ${ }^{a}$ ed. Buenos Aires: Depalma, 1990, pp. 4-6.

${ }^{76}$ CALAIS-AULOY, Jean; STEINMETZ, Frank. Droit de la consommation. 4. ${ }^{\mathrm{a}}$ ed. Paris: Dalloz, 1996, pp. 11-12.
} 
Como já registramos alhures, sob o ponto de vista dos destinatários os serviços públicos são classificados em 'uti singuli' - o serviço individualizado, prestado a pessoa determinada e de forma divisível - e 'uti universis' - prestado a toda coletividade, de forma indistinta e indivisível.

Quanto à forma de prestação, os serviços públicos podem ser prestados diretamente pelo Estado ou indiretamente, por meio de terceiros que agem em nome do Estado por meio de delegação (como ocorre nos casos de concessões, permissões e autorizações de serviços públicos).

Necessário se faz, também, esclarecer a forma de remuneração desses serviços, que pode ser por meio de taxa, tarifa ou preço público. Taxa é uma espécie de tributo, destinada à remuneração de serviço público específico e divisível. ${ }^{77}$ Justamente por ser tributo é compulsória, sendo sua cobrança condicionada à prévia autorização orçamentária. ${ }^{78}$ Os serviços remunerados mediante taxa são os serviços uti universi. ${ }^{79-80}$

Tarifa, por sua vez, é a forma de remuneração dos serviços uti singuli - serviços prestados a usuários determinados, individualmente - como, por exemplo, os serviços de água, telefone, gás canalizado etc. ${ }^{81}$ São serviços colocados à disposição do usuário, cuja adesão é facultativa, cabendo ao usuário decidir ou não pela utilização. ${ }^{82}$

\footnotetext{
77 "Divisível" no sentido de que é possível mensurar a contraprestação de cada usuário, posto que o serviço é prestado de forma coletiva e imposto a todos - e neste sentido, indivisível.

${ }^{78}$ Neste sentido, a Súmula 545 do STF: "Preços de serviços públicos e taxas não se confundem, porque estas, diferentemente daqueles, são compulsórias e têm sua cobrança condicionada à prévia autorização orçamentária, em relação à lei que as instituiu."

${ }^{79}$ Odete Medauar cita como exemplos de serviços uti universi - ou, nas suas palavras, "serviços sem destinatários determinados" - os serviços de coleta de lixo, limpeza de ruas e iluminação pública. (MEDAUAR, Odete. Direito Administrativo Moderno. 11. ${ }^{a}$ ed. São Paulo: Revista dos Tribunais, 2007, p. 317).

${ }^{80}$ Esclareça-se que os serviços uti universis podem também ser remunerados por meio de tributos em geral, sem necessariamente ser cobrado diretamente do usuário.

${ }^{81}$ Ibidem, mesma página.

${ }^{82}$ GASPARINI, Diógenes. Direito Administrativo. 11. ${ }^{a}$ ed. São Paulo: Saraiva, 2006, pp. $294-$ 295.
} 
Os serviços públicos delegados a concessionários, permissionários ou autorizatários são remunerados por meio de tarifas, conforme orientação do Supremo Tribunal Federal, do Ministro Cezar Peluso:

(...) A partir do momento em que o serviço passa a ser prestado por uma concessionária, a forma da respectiva remuneração transmuda-se em tarifária (preço público), como é da essência dos serviços concedidos, a teor do que dispõe o Art. 175, II, da Lex Mater, até porque, ao se afirmar que determinado serviço só pode ser remunerado mediante taxa, se está, concomitantemente, negando-lhe a possibilidade de ser concedido (...). ${ }^{83}$

Preço público, por sua vez, "é a contraprestação pecuniária do objeto da licitação, podendo ser global ou unitária, fixa ou reajustável, único ou com aditamento de parcelas variáveis". ${ }^{84}$

A principal distinção entre preço público e tarifa, portanto, é que esta perfaz uma receita do particular - concessionário, permissionário etc. - ao passo que aquele gera uma receita para o Estado.

Feitas essas considerações, verifiquemos a questão atinente à aplicação do Código de Defesa do Consumidor aos serviços públicos. Tanto em relação aos serviços uti singuli quanto aos uti universi, nota-se sensível divergência - notadamente no seio da doutrina - em relação à aplicação da legislação consumerista aos serviços públicos.

Em relação aos serviços uti universi, substancial parcela da doutrina entende pela inaplicabilidade do Código de Defesa do Consumidor a tais serviços, precisamente em razão da natureza da remuneração dos mesmos, que é feita por meio de taxa ou, muitas vezes, por tributos em geral. Em tais

${ }^{83}$ BRASIL. Supremo Tribunal Federal. AI 678004/SC, Rel. Min. Cezar Peluso, Brasília, 04/10/2007. Disponível na internet em: http://www.stf.jus.br. Acesso em: 08/04/2008.

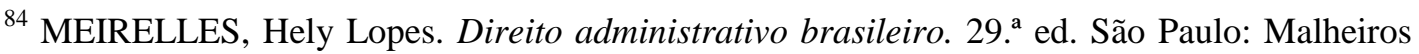
Editores, 2004, p. 298. 
hipóteses, ingressar-se-ia no âmbito das relações de Direito Público, não havendo a incidência do CDC nessas relações jurídicas ${ }^{85}$, posição que temos por absolutamente correta.

É neste sentido, aliás, que conclui o Ministério Público do Estado de São Paulo, em Súmula editada em 1992, atualizada em 1996, mas que se mantém inteiramente atual:

CENACON n. ${ }^{\circ} 6$ - SERVIÇO PÚBLICO - OBJETO DE PROTEÇÃO PELO CÓDIGO DE DEFESA DO CONSUMIDOR - 'UTI SINGULI': São objeto de tutela pelo Código do Consumidor, e de atribuição das Promotorias de Justiça do Consumidor, os serviços públicos prestados uti singuli e mediante retribuição por tarifa ou preço público, quer pelo Poder Público diretamente, quer por empresas concessionárias ou permissionárias, sobretudo para os efeitos do seu art. 22. Não o são, porém, os serviços públicos prestados uti universi como decorrência da atividade precípua do Poder Público e retribuídos por taxa ou pela contribuição a título de tributos em geral. Nesse caso, tais serviços poderão ser objeto de inquérito civil e ação civil pública pelo Ministério Público, mas por intermédio do setor de defesa dos direitos do cidadão (Junho de 1992, atualizada em maio de 1996). ${ }^{86}$

Em contraposição, Rizzatto Nunes afirma que, independente de ser uti singuli ou uti universi, o serviço público sempre estará submetido às normas previstas no Código de Defesa do Consumidor, visto não haver distinção em relação à classificação do serviço público, posto que o artigo $3 .^{\circ}, \S 2 .^{\circ}$ do

\footnotetext{
${ }^{85}$ Cf. FILOMENO, José Geraldo Brito. Manual de Direitos do Consumidor. 8. a ed. São Paulo: Atlas, 2005, pp. 41-42, MARQUES, Cláudia Lima. BENJAMIN, Antônio Herman V. MIRAGEM, Bruno. Comentários ao Código de Defesa do Consumidor. 2. ${ }^{a}$ ed. São Paulo: Revista dos Tribunais, 2006, p. 381, GRINOVER, Ada Pellegrini. Et. al. Código Brasileiro de Defesa do Consumidor comentado pelos autores do anteprojeto. 8. ${ }^{\mathrm{a}}$ ed. Rio de Janeiro: Forense Universitária, 2004, p. 49.

${ }^{86}$ FILOMENO, José Geraldo Brito. Promotorias de justiça do Consumidor: "Evolução. Metas e Prioridades”. Revista Justitia, São Paulo, n. ${ }^{\circ}$ 54, out./dez. 1992, p. 225.
} 
CDC dispõe que serviço é qualquer atividade prestada no mercado de consumo. $^{87}$

Em relação aos serviços uti singuli, a doutrina também diverge acerca da aplicação do Código de Defesa do Consumidor.

Pela não aplicação da legislação consumerista, Antônio Carlos Cintra do Amaral defende que usuário de serviço público não pode ser confundido com consumidor. Ressaltando o equívoco da afirmação de que o usuário de serviço público seria um consumidor, sustenta que tal equivalência seria possível sob a ótica econômica. ${ }^{88}$ Todavia, ressalva o autor, "sob a ótica jurídica o usuário de serviço público e o consumidor estão em situações distintas. Uma coisa é a relação jurídica de serviço público. Outra, a de consumo." 89

A justificativa é a de que as pessoas que prestam serviços públicos por delegação - e.g., concessionárias, permissionárias - o fazem por meio de um contrato administrativo regido por regras próprias de Direito Público. A prestação de serviço público diferencia-se da prestação de serviço no âmbito privado pelo fato de haver regras e normas impostas a esses contratos.

Segundo essa linha de pensamento, entre as pessoas nessa relação jurídica há uma relação tríplice, ligando o usuário à concessionária e a

${ }^{87}$ NUNES, Rizzatto. Comentários ao Código de Defesa do Consumidor. 2. ${ }^{\text {a }}$ ed. São Paulo: Saraiva, 2005, pp. 112 e 318-320.

Dispõe referido preceito: Art. $3 .^{\circ}$ Fornecedor é toda pessoa física ou jurídica, pública ou privada, nacional ou estrangeira, bem como os entes despersonalizados, que desenvolvem atividade de produção, montagem, criação, construção, transformação, importação, exportação, distribuição ou comercialização de produtos ou prestação de serviços. $\S 1 .^{\circ}$ Produto é qualquer bem, móvel ou imóvel, material ou imaterial. § $2{ }^{\circ}$ Serviço é qualquer atividade fornecida no mercado de consumo, mediante remuneração, inclusive as de natureza bancária, financeira, de crédito e securitária, salvo as decorrentes das relações de caráter trabalhista." (os negritos são nossos).

88 AMARAL, Antônio Carlos Cintra do. Distinção entre usuário de serviço público e consumidor. Revista Diálogo Jurídico, Salvador, CAJ - Centro de Atualização Jurídica, n. ${ }^{\circ} 13$, abril-maio, 2002. Disponível na internet: http://www.direitopublico.com.br. Acesso em 01/10/2010.

${ }^{89}$ Ibidem, mesma página. Disponível na Internet: http://www.direitopublico.com.br. Acesso em: 01/10/2010. 
concessionária ao Poder Público, havendo, portanto, um contrato principal (firmado entre o Poder Público e a concessionária) e um contrato acessório (firmado entre a concessionária e o consumidor). Desta forma, a relação jurídica entre o usuário do serviço público e a concessionária não pode ser equiparada a uma relação jurídica duas pessoas privadas, pois há um contrato administrativo envolvido, regido pelo Direito Público, havendo, portanto, a incidência da Lei $8.987 / 95$.

De outra sorte, há quem, ainda no seio da doutrina, defenda que o Código de Defesa do Consumidor aplica-se aos serviços públicos uti singuli, justamente pelo fato de haver remuneração por tarifa ou preço público, além de ser um serviço facultativo ao usuário e divisível. ${ }^{90}$ Neste sentido, há decisão da Segunda Turma do Superior Tribunal de Justiça, no Agravo Regimental no

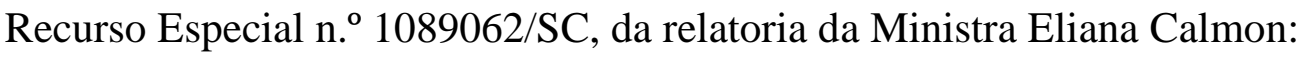

"ADMINISTRATIVO - SERVIÇO PÚBLICO - ENERGIA ELÉTRICA - TARIFAÇÃO - COBRANÇA POR FATOR DE DEMANDA DE POTÊNCIA - LEGITIMIDADE. 1. Os serviços públicos impróprios ou UTI SINGULI prestados por órgãos da administração pública indireta ou, modernamente, por delegação a concessionários, como previsto na CF (art. 175), são remunerados por tarifa, sendo aplicáveis aos respectivos contratos o Código de Defesa do Consumidor. (...) Recurso especial provido pela divergência." $" 91$

Na visão de outros doutrinadores, como Cláudia Lima Marques, o Código de Defesa do Consumidor e a Lei de Concessões e Permissões devem ser aplicadas de forma harmônica, com o fim de proteger o consumidor. É neste

\footnotetext{
${ }^{90}$ Cf. FILOMENO, José Geraldo Brito. Manual de Direitos do Consumidor. 8. ${ }^{\text {a ed. São Paulo: }}$ Atlas, 205, pp. 41-42; MARQUES, Claudia Lima. BENJAMIN, Antônio Herman V. MIRAGEM, Bruno. Comentários ao Código de Defesa do Consumidor. 2. ${ }^{a}$ ed. São Paulo: Revista dos Tribunais, 2006, p. 381, GRINOVER, Ada Pellegrini. Et. al. Código Brasileiro de Defesa do Consumidor comentado pelos autores do anteprojeto. 8. ${ }^{\mathrm{a}}$ ed. Rio de Janeiro: Forense Universitária, 2004, p. 49.

${ }^{91}$ BRASIL. Superior Tribunal de Justiça. AgRg no REsp 1089062/SC, Min. Eliana Calmon, Brasília, 01 de setembro de 2009. Disponível na internet em: http://www.stj.jus.br. Acesso em: $12 / 12 / 2010$.
} 
sentido a conclusão n. ${ }^{\text {o }} 2$ do V Congresso Brasileiro de Direito do Consumidor, ocorrido em maio de 2000, em Belo Horizonte, aprovada por unanimidade e onde se lê: "2. Aplicam-se as normas do CDC aos serviços públicos executados mediante o regime da concessão cabendo ao intérprete potencializar a utilização das normas do Código em conjunto com as regras protetivas do consumidor, existentes nas leis específicas que regulam cada um dos serviços."92

Feitas essas considerações, permitimo-nos concluir pela submissão do Estado às normas protetivas do consumidor no âmbito dos serviços públicos uti singuli.

Todavia, no que diz respeito aos serviços uti universi, a conclusão deve ser diametralmente oposta, é dizer, pela inaplicabilidade do Código de Defesa do Consumidor, precisamente em razão da natureza da remuneração dos mesmos. Em situações assim, como visto, ingressar-se-ia no âmbito das relações de Direito Público, não havendo espaço, portanto, para a incidência do Código de Proteção e Defesa do Consumidor.

Em suma, endossa-se, no particular, o entendimento firmado pelo Superior Tribunal de Justiça, que já reconheceu a inaplicabilidade do Código de Proteção e Defesa do Consumidor “Quando o serviço público é prestado diretamente pelo Estado e custeado por meio de receitas tributárias", na medida em que "não se caracteriza uma relação de consumo.",93

\footnotetext{
92 MARQUES, Cláudia Lima. Contratos no código de defesa do consumidor: o novo regime das relações contratuais. 4. ${ }^{a}$ ed. São Paulo: Revista dos Tribunais, 2002, p. 488.

${ }^{93}$ BRASIL. Superior Tribunal de Justiça. REsp 1187456/RJ, relator Min. Castro Meira, disponibilizado no DJe 01/12/2010. Disponível na internet em: http://www.stj.jus.br. Acesso em: 02/02/2011.
} 


\section{PRINCÍPIOS ADMINISTRATIVOS}

\subsection{Princípios: força normativa e particular relevância no âmbito do direito administrativo}

Não é possível iniciar o estudo do princípio da continuidade dos serviços públicos, núcleo central deste trabalho, sem passar os olhos sobre o significado e o papel desempenhado pelos princípios (e, em particular os constitucionais, como se verá adiante) no âmbito do direito administrativo.

Não pretendemos, nesta oportunidade, estudar a teoria dos princípios, nem tampouco realizar exaustiva análise dos princípios regentes do direito administrativo. E nem poderíamos: é reconhecidamente árdua a tarefa de superar a dificuldade na conceituação, delimitação e nas várias classificações dos princípios, notadamente quando se sabe que este assunto já recebeu - não sem a devida polêmica - a atenção e o cuidado magistral de vários professores que se dedicaram exclusivamente ao tema.

A nossa pretensão no desenvolvimento deste item é, diferentemente, outra: a partir do reconhecimento da posição dos princípios na seara do Direito Administrativo, abrir caminho para o exame daqueles princípios que interferem diretamente em nossa temática e, por isso, exigirão alguma atenção, como ponto de partida para a resposta às nossas indagações quanto à incidência e repercussões da continuidade do serviço público.

Vozes da doutrina ecoam unissonamente ao ressaltar a importância dos princípios - que diferem das regras - dentro de um ordenamento jurídico.

Seguindo-se a clássica obra de Robert Alexy (Teoria dos direitos fundamentais), temos que regras e princípios são espécies de uma categoria 
maior - a de normas - porque formulados por intermédio de expressões deônticas básicas do dever, da permissão e da proibição, ou seja, ambos funcionando como razões para juízos concretos de dever-ser. Embora referido autor reconheça que o critério da generalidade seria o mais utilizado com vistas à distinção entre princípios e regras, não existiria uma diferença em termos de grau entre as duas espécies (princípios e regras), mas, diferentemente, tão só e apenas qualitativa. São suas as palavras:

Princípios são, (...), mandamentos de otimização, que são caracterizados por poderem ser satisfeitos em graus variados e pelo fato de que a medida devida de sua satisfação não depende somente das possibilidades fáticas, mas também das possibilidades jurídicas. $\mathrm{O}$ âmbito das possibilidades jurídicas é determinado pelos princípios e regras colidentes.

Já as regras são normas que são sempre ou satisfeitas ou não satisfeitas. Se uma regra vale, então, deve se fazer exatamente aquilo que ela exige; nem mais, nem menos. Regras contêm, portanto, determinações no âmbito daquilo que é fática e juridicamente possível. ${ }^{94}$

Alexy ressalta que a distinção entre regras e princípios revela-se mais claramente nos casos de colisões entre princípios e de conflitos entre regras. Enquanto o conflito de regras resolver-se-ia pelo reconhecimento de uma cláusula de exceção ou pela declaração da invalidade de uma delas, a colisão de princípios significaria apenas que um deles teria precedência sobre o outro. Estar-se-ia diante do fenômeno que Alexy denomina de 'relação de precedência condicionada', na qual o conflito seria resolvido pelo sopesamento dos

${ }^{94}$ ALEXY, Robert, Teoria dos direitos fundamentais. Tradução de Virgílio Afonso da Silva. São Paulo: Malheiros Editores, 2008. pp. 90-91. 
interesses em choque, de molde a definir qual deles deveria ser aplicado no caso em concreto. ${ }^{95}$

É bom deixar claro que, para o autor, tal escolha (ou precedência) de um princípio em detrimento de outro não representa a invalidação de um deles, nem tampouco a introdução da cláusula de exceção, como se passa com as regras, mas apenas e tão somente que um dos princípios tem um peso maior, naquela situação, dadas as circunstâncias daquele caso concreto. ${ }^{96}$

Evidenciando o papel de destaque que os princípios (referindo-se em particular aos constitucionais) desempenham em um sistema jurídico, José Gomes Canotilho anota, em posição que adotamos: "Os princípios constitucionais fornecem sempre diretivas materiais de interpretação das normas constitucionais. E, mais, os princípios beneficiam de (1) uma objetividade e presencialidade normativa que os dispensa de estarem consagrados expressamente em qualquer preceito particular (e.g., não era pelo fato de CRP em 1976 não ter consagrado o princípio do Estado de Direito que ele deixava de ter presença normativa e valor constitucional, dado que ele podia deduzir-se de vários preceitos constitucionais); (2) os princípios carecem de uma mediação semântica mais intensa, dada a sua idoneidade normativa irradiante ser, em geral, acompanhada por uma menor densidade concretizadora (por ex.: o princípio democrático pode ser esgrimido com o princípio de interpretação, mas, em geral, ele está concretizado em outras normas da Constituição)." 97

Trilhando esta mesma linha metodológica, doutrinadores brasileiros têm-se ocupado de ressaltar a relevância dos princípios em um sistema jurídico, erigindo-os à categoria superior a das regras. ${ }^{98}$ Em clássica

\footnotetext{
95 ALEXY, Robert. Teoria dos direitos fundamentais, Tradução de Virgílio Afonso da Silva. São Paulo: Malheiros Editores, 2008. pp. 91-92.

96 Ibidem, mesmas páginas.

97 CANOTILHO, José Gomes. Direito Constitucional. 3. a ed., Coimbra: Almedina, 1983, pp. 199-200.

${ }^{98}$ Geraldo Ataliba acentuara o status dos princípios, "chave e essência” de todo o direito, e para quem as simples regras jurídicas de nada valem se não estiverem apoiadas em princípios.
} 
lição, Miguel Reale já afirmara: princípios “são enunciações normativas de valor genérico, que condicionam e orientam a compreensão do ordenamento jurídico, quer para a sua aplicação e integração, quer para a elaboração de novas normas". 99 Além de expressa referência na Constituição Federal (art. 5. , $\left.\S 2 .^{\circ}\right)^{100}$, a Lei de Introdução ao Código Civil (Dec.-lei 4.657/42) enuncia os princípios gerais do direito não apenas como mecanismo de integração, mas também de interpretação do direito (art. $4 .^{\circ}$ ).

Os princípios constituem, portanto, a base estrutural de todo o ordenamento jurídico, funcionando como verdadeiro ponto de referência do sistema. São normas elementares e fundamentos que funcionam como lastro para a aplicação do direito ou, como prefere Celso Antônio Bandeira de Mello:

Princípio - já averbamos alhures - é, por definição, mandamento nuclear de um sistema, verdadeiro alicerce dele, disposição fundamental que se irradia sobre diferentes normas compondo-lhes o espírito e servindo de critério para sua exata compreensão e inteligência exatamente por definir a lógica e a racionalidade do sistema normativo, no que lhe confere a tônica e lhe dá sentido harmônico. É o conhecimento dos princípios que preside a intelecção das diferentes partes componentes do todo unitário que há por nome sistema jurídico positivo. ${ }^{101}$

É importante assinalar, seguindo a lição de Celso Antônio Bandeira de Mello, que a violação a "um princípio é muito mais grave do que

(ATAliBA, Geraldo. Mudança da Constituição, Revista de Direito Público, São Paulo, n. ${ }^{\circ} 86$, pp. 181-186, abr./jun.1988, p. 181).

${ }^{99}$ REALE, Miguel. Lições Preliminares de Direito, 27. a ed., São Paulo: Saraiva, 2002, p. 304.

${ }^{100}$ In verbis: "Art. 5. ${ }^{\circ}$ Todos são iguais perante a lei, sem distinção de qualquer natureza, garantindo-se aos brasileiros e aos estrangeiros residentes no País a inviolabilidade do direito à vida, à liberdade, à igualdade, à segurança e à propriedade, nos termos seguintes: (...) § $2 .^{\circ}-$ Os direitos e garantias expressos nesta Constituição não excluem outros decorrentes do regime e dos princípios por ela adotados, ou dos tratados internacionais em que a República Federativa do Brasil seja parte."

${ }^{101}$ MELLO, Celso Antônio Bandeira de. Curso de Direito Administrativo, 27. a ed., São Paulo: Malheiros Editores, 2010, pp. 958-959. 
transgredir uma norma. A desatenção ao princípio implica ofensa não apenas a um específico mandamento obrigatório, mas a todo o sistema de comandos. É a mais grave forma de ilegalidade ou inconstitucionalidade, conforme o escalão do princípio atingido, porque representa insurgência contra todo o sistema, subversão de seus valores fundamentais, contumélia irremissível a seu arcabouço lógico e corrosão de sua estrutura mestra."102

Os princípios, porém, assume relevância crucial quando se está diante da Administração Pública ou, mais propriamente, do direito administrativo. São exatamente os princípios - e, em particular e com muita força, dois deles, como se verá a seguir - que conferem ao Direito Administrativo coerência e unidade, permitindo ser reconhecido como, de fato, "um regime jurídico-administrativo."

Segundo José Roberto Dromi, princípios jurídicos da função administrativa são as cláusulas pétreas do ordenamento jurídico administrativo que imperam em todo o modelo da Administração Pública, ou, em outras palavras, princípios que explicitam o conteúdo da própria função administrativa. ${ }^{103}$

A unidade sistemática desses princípios regentes ou guias forma, por assim dizer, o regime administrativo, permitindo que se lhe reconheça autonomia e, sobretudo, identidade. Tal observação já fôra, há muito, feita por Celso Antônio Bandeira de Mello, para quem "[é] questão assente entre todos os doutrinadores a existência de uma unidade sistemática de princípios e normas que formam em seu todo o Direito Administrativo."

\footnotetext{
${ }^{102}$ MELLO, Celso Antônio Bandeira de. Curso de Direito Administrativo. 27. ${ }^{\text {a }}$ ed. São Paulo: Malheiros Editores, 2010, p. 959.

${ }^{103}$ DROMI, José Roberto. Derecho administrativo. Tomo 1. Buenos Aires: Ástrea, 1992, p. 60. ${ }^{104}$ Ibidem, p. 53.

105 Odete Medauar, referindo-se aos princípios do direito administrativo, pontua: "Tendo em vista que as atividades da Administração Pública são disciplinadas preponderantemente pelo direito administrativo, tais princípios podem ser considerados também princípios jurídicos da Administração Pública brasileira." (MEDAUAR, Odete. Direito Administrativo Moderno. 11. ${ }^{\text {a }}$ ed. rev., atual. e ampl. São Paulo: Revista dos Tribunais, 2007, p. 119).
} 
Hartmut Maurer faz observação equivalente à luz do sistema jurídico alemão. A ausência de regulações legais explica, segundo Maurer, o motivo para o direito administrativo ter sido, e ainda hoje ser, determinado por seus princípios gerais. ${ }^{106}$

O direito administrativo é, pois, composto fundamentalmente por características pertencentes ao direito público, mas não sem ressalvas. A essa corpo de regras essencialmente de direito público se acrescem algumas peculiaridades, fazendo surgir o que se denomina 'regime jurídico administrativo'.

Com efeito, segundo observa Hely Lopes Meirelles, o Direito Administrativo "não é refratário, em linhas gerais, às aplicações análogas das regras do Direito Privado, mesmo porque já não se pode mais considerá-lo um Direito excepcional.” Entretanto, prossegue o mesmo autor,

sendo um ramo do Direito Público, nem todos os princípios de hermenêutica do direito privado lhe são aplicáveis. A diversidade do seu objeto, a natureza específica de suas normas, os fins sociais a que elas se dirigem, o interesse público a que ela visa sempre tutelar, exigem regras próprias de interpretação e aplicação das leis, atos e contratos administrativos. ${ }^{107}$

Em suma, os princípios podem ser compreendidos como postulados legitimadores de todo o ordenamento jurídico, na exata medida em que, introduzidos na consciência jurídica de um Estado, impõem a todos os órgãos integrantes da Administração Pública a realização de seus fins quando da consecução de suas atividades, revelando-se, assim, como verdadeira garantia para os cidadãos.

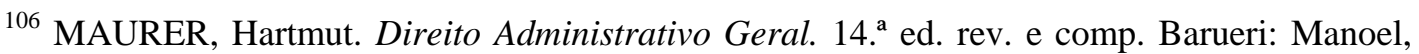
2006, p. 78.

${ }^{107}$ MEIRELLES, Hely Lopes. Direito Administrativo Brasileiro. 29. ${ }^{\mathrm{a}}$ ed. São Paulo: Malheiros Editores, 2004, p. 49.
} 
Nessa senda, consoante também se frisou, em razão da elaboração recente $^{108}$ e não codificada do Direito Administrativo brasileiro, há que se ter sempre presente a importância dos princípios para esse ramo do Direito: justamente por conta destes postulados permite-se compreender e consolidar os institutos, adotar soluções para casos não previstos em lei, além de uma função eminentemente positiva: a de influenciar na elaboração de normas. ${ }^{109} \mathrm{E}$ mais, permite que a Administração Pública, à vista desses postulados, atue sempre em vista do (necessário) equilíbrio as suas prerrogativas e os direitos dos administrados. $^{110}$

Conclui-se, assim, que as normas elementares ou requisitos primordiais instituídos como alicerce do Direito Administrativo brasileiro e da Administração Pública estão constituídos por princípios, sejam eles gerais ou específicos, explícitos ou implícitos. Daí a inocultável importância do estudo ainda que, como é natural, não exaustivo - dos mais relevantes princípios que servem de base ao regime jurídico-administrativo, consoante se examina no próximo Capítulo (Capítulo 2, infra).

\footnotetext{
108 "Como ramo jurídico", anota Odete Medauar, "o direito administrativo é de criação recente, pois começou a ser elaborado há cerca de um século e meio. Antes de se formar um conjunto sistematizado de normas para reger a atividade administrativa estatal, havia a Administração Pública e havia também alguns preceitos esparsos a respeito. Além de não formarem um todo sistematizado, tais preceitos não podiam ser invocados pelos indivíduos para contrapor direitos seus perante a atuação da Administração (...)." (MEDAUAR, Odete. Direito Administrativo Moderno. 11. a ed. rev., atual. e ampl. São Paulo: Revista dos Tribunais, 2007, p. 34 - os grifos são do original)

${ }^{109}$ As funções positiva e negativa dos princípios são objeto de destaque na obra de Odete Medauar, fartamente amparada nas lições de Karl Larenz. (Ibidem, p. 120).

${ }^{110}$ Odete Medauar observa a crescente importância dos princípios do direito administrativo no âmbito do chamado "direito administrativo comunitário" europeu, onde a Corte de Justiça da União Européia vem se valendo dos princípios para a solução de muitas questões. (Ibidem, mesma página).
} 


\subsection{Princípios 'explícitos' versus 'implícitos'}

Estabelecida a importância (particularmente destacada) dos princípios no direito administrativo, convém divisar os chamados princípios constitucionais explícitos, de um lado, e os implícitos, de outro.

A Constituição da República de 1988, no artigo 37 e ao longo de todo o texto, consagra os princípios e normas fundamentais acerca da organização do Estado e do desenvolvimento da atividade administrativa. Mas, de maneira expressa, em sua redação original, reportou à Administração Pública apenas e tão somente quatro princípios: o da legalidade, da impessoalidade, da moralidade e da publicidade. A Reforma Administrativa implementada pela Emenda Constitucional 19/98 acresceu a referido rol (do art. 37) o princípio da eficiência. Estes são os princípios comumente designados como expressos ou explícitos.

Como ressalta Celso Antônio Bandeira de Mello, porém, “inúmeros outros [princípios] mereceram igualmente consagração constitucional: uns, por constarem expressamente da Lei Maior, conquanto não mencionados no art. 37, caput; outros por nele estarem abrigados logicamente, isto é, como consequências irrefragáveis dos aludidos princípios; outros, finalmente, por serem implicações evidentes do próprio Estado de Direito e, pois, do sistema constitucional como um todo." ${ }^{111}$ Em contraposição ao bloco anterior, esses postulados integram a categoria dos princípios implícitos.

Dois dos maiores - e quiçá mais relevantes - princípios do Direito Administrativo brasileiro não receberam previsão expressa no referido art. 37 , da CF. Pode-se dizer, de toda a sorte, que todo o regime jurídico-administrativo está calcado fundamentalmente neles: o princípio da preponderância do interesse público sobre o interesse privado e o da indisponibilidade pela Administração

${ }^{111}$ MELLO, Celso Antônio Bandeira de. Curso de Direito Administrativo. 27. a ed. São Paulo: Malheiros Editores, p. 95. 
dos interesses públicos. Há outros de imenso relevo e que também não constam daquele rol, tais como princípio da razoabilidade, da proporcionalidade e, para o que nos interessa muito de perto, o próprio princípio da continuidade.

Mas, afinal, qual a importância de se identificar e/ou compreender o significado e a extensão destes princípios, notadamente dos implícitos? A esta questão pode-se responder com as lições de Celso Antônio Bandeira de Mello, que ressalta:

Advirta-se, outrossim, que as normas, justamente por serem regras expressas, encontram-se à imediata disposição do intérprete e, bem por isso, não apresentam qualquer dificuldade em serem localizadas. De extrema importância, isto sim, é desvendar os princípios acolhidos no sistema; isto é, os que se encontram vazados nas diversas normas administrativas, informando suas disposições, embora não se achem formal ou categoricamente expressos. ${ }^{112}$

Nada mais verdadeiro. Se se almeja compreender e interpretar o Direito Administrativo - ou um braço dele, como o tema central deste trabalho e toda a problemática que o envolve -, parece fundamental um estudo dos cânones sobre os quais estão assentados o regime jurídico-administrativo, em particular o da preponderância do interesse público e da indisponibilidade dos interesses públicos pela Administração.

A tudo isso se deve somar outra particularidade: o princípio da continuidade, não expressamente albergado no texto do art. 37, da CF, é desmembramento de outros princípios, do que resulta (por mais essa razão) o imperativo do exame de referidos princípios, genuínos pressupostos ao exame do objeto deste trabalho.

As seguintes linhas não pretendem realizar exaustiva enumeração dos princípios regentes do Direito Administrativo, nem tampouco uma reflexão

${ }^{112}$ MELLO, Celso Antônio Bandeira de. Curso de Direito Administrativo. 27. a ed. São Paulo: Malheiros Editores, p. 89. 
em torno de cada um deles. Entretanto, como já vislumbrado, porque o objeto deste trabalho é o enfrentamento do princípio da continuidade, seus efeitos e repercussões, parece fundamental - porque pressuposto - o exame daqueles princípios que impactam diretamente no tema, de molde a exigir, desde logo, a nossa atenção. Por isso, voltaremos nosso foco para os princípios da preponderância do interesse público sobre o interesse privado; da indisponibilidade da Administração Pública (dos interesses públicos); da razoabilidade, da proporcionalidade e da eficiência.

\subsection{Princípios da preponderância do interesse público sobre o privado e da indisponibilidade do interesse público}

O princípio da preponderância ${ }^{113-114}$ do interesse público sobre o particular, princípio geral informador de todo o ordenamento jurídico ${ }^{115}$, foi

${ }^{113}$ Correntemente, a doutrina emprega a expressão supremacia do interesse público (DI PIETRO, Maria Sylvia Zanella. Direito Administrativo. 20. ${ }^{a}$ ed. São Paulo: Atlas, 2007, p. 59; GASPARINI, Diógenes. Direito Administrativo. 11. a ed. São Paulo: Saraiva, 2006, p. 20; JUSTEN FILHO, Marçal. Curso de Direito Administrativo. 2. ed. São Paulo: Saraiva, 2006, p. 36; MEIRELLES, Hely Lopes. Direito Administrativo Brasileiro. 29. ${ }^{a}$ ed. São Paulo: Malheiros Editores, p. 101; MELLO, Celso Antônio Bandeira de. Curso de Direito Administrativo. 27. ${ }^{\text {a }}$ ed. São Paulo: Malheiros Editores, 2010, p. 69). Preferimos falar em preponderância do interesse público, expressão adotada ao longo de todo este trabalho, no que acompanhamos o ensinamento de Odete Medauar (MEDAUAR, Odete. Direito Administrativo Moderno, 11. ${ }^{\mathrm{a}}$ ed. rev., atual. e ampl. São Paulo: Revista dos Tribunais, 2007, p. 128).

${ }^{114}$ Supremacia, conceito que temos por ultrapassado, transmite a falsa sensação de um Estado absoluto e que os interesses relativos ao coletivo jamais podem ser afastados, nem mesmo diante de direitos fundamentais individuais. Já a noção de preponderância implica em estabelecer que, num primeiro momento, o interesse público deve prevalecer, mas não deve sobrepor-se a direitos fundamentais individuais, apenas e tão somente quando a própria Constituição ou a lei assim prever. Constatação válida de ser feita, à luz do Direito Administrativo moderno, é a de que a visão de supremacia (para nós, preponderância) sofre sensível mutação, transformando-se em algo mais "relativizado", preservando uma esfera do individual em que o Estado não tem alcance, ainda que seja em nome do interesse público. Em emblemática passagem, Diogo de Figueiredo Moreira Neto chancela essa opinião: “(...) no Estado Democrático de Direito, não há mais fundamento para sustentar-se o antigo princípio da supremacia do interesse público, que partia da existência de uma hierarquia automática entre as 
criado no século XIX, em um cenário de transição, já que o direito deixava de ser um instrumento de garantia apenas dos direitos individuais, para assumir a posição de instrumento na persecução do bem coletivo.

Com efeito, em nome do primado do interesse público, a Administração Pública necessariamente deve ocupar um patamar de superioridade em relação aos particulares. Neste sentido, qualquer conflito entre um interesse particular e um interesse público coletivo ${ }^{116}$, este último, sem dúvida, deverá prevalecer.

categorias de interesses públicos e privados. Na verdade, tal relação fixa não existe, porque, em princípio, no Estado Democrático de Direito, quaisquer interesses só podem estar subordinados ou supraordinados, uns aos outros, conforme disponha a lei. (...) Assim, tanto a definição do interesse público quanto à imposição de sua eventual supremacia sobre quaisquer outros interesses, igualmente agasalhados pela ordem jurídica, como o são, e, preeminentemente, os já referidos, as liberdades, os direitos e as garantias fundamentais, dependerão, única e exclusivamente, das opções que sejam feitas na Constituição e nas leis. Revertendo enfaticamente os termos: os direitos e garantias fundamentais só cedem ante a uma expressa preceituação constitucional e, assim mesmo, restritamente, quando, como e onde essa supremacia se impuser." (MOREIRA NETO, Diogo de Figueiredo. Curso de Direito Administrativo. 14. ${ }^{a}$ ed. Rio de Janeiro: Forense, 2005, p. 81).

115 Gustavo Binenbojm rejeita a existência do princípio da supremacia do interesse público, sustentando: "Veja-se que não se nega, de forma alguma, o conceito de interesse público, mas tão-somente a existência de um princípio da supremacia do interesse público. Explica-se: se o interesse público, por ser um conceito jurídico determinado, só é aferível após juízos de ponderação entre direitos individuais e metas ou interesses coletivos, feitos à luz de circunstâncias concretas, qual o sentido em falar-se num princípio jurídico que apenas afirme que, no final, ao cabo do processo ponderativo, se chegará a uma solução (isto é, ao interesse público concreto) que sempre prevalecerá? Em outras palavras: qualquer que seja o conteúdo deste "interesse público" obtido em concreto, ele sempre prevalecerá. Ora, isso não é um princípio jurídico. Um princípio que se presta a afirmar que o que há de prevalecer sempre prevalecerá não é um princípio, mas uma tautologia. Daí se propor que é o postulado da proporcionalidade que, na verdade, explica como se define o que é o interesse público, em cada caso. O problema teórico verdadeiro não é a prevalência, mas o conteúdo do que deve prevalecer. A preservação, na maior medida possível, dos direitos individuais constitui porção do próprio interesse público. São metas gerais da sociedade política, juridicamente estabelecidas, tanto viabilizar o funcionamento da Administração Pública, mediante instituição de prerrogativas materiais e processuais, como preservar e promover, da forma mais extensa quanto possível, os direitos dos particulares. Assim, esse esforço de harmonização não se coaduna com qualquer regra absoluta de prevalência a priori dos papéis institucionais do Estado sobre os interesses individuais privados." (BINENBOJM, Gustavo. A supremacia do interesse público sobre o particular ao dever de proporcionalidade: um novo paradigma para o direito administrativo. Revista de Direito Administrativo, v. 239. Rio de Janeiro: Renovar, jan./mar. 2005, p. 30).

116 A expressão interesse coletivo é adotada, ao longo deste trabalho, como equivalente a interesse público. Este, por sua vez, "fundamento, fim e limite" de atos e medidas da Administração e do direito administrativo que é, como apregoa Odete Medauar (Direito Administrativo Moderno, 11. ${ }^{\text {a }}$ ed. rev., atual. e ampl. São Paulo: Revista dos Tribunais, 2007, p. 
Em sua substância, o princípio da preponderância do interesse público representa a necessidade de sacrifício de interesses individuais, quando o que se busca é o atendimento das necessidades da coletividade. A defesa do interesse público, portanto, está intimamente ligada à atuação estatal.

Com efeito, para a realização dos interesses da coletividade, uma série de prerrogativas foram conferidas à Administração, dentre as quais se enumeram: a possibilidade de constituir terceiros em obrigações mediante atos unilaterais; a exigibilidade e a auto-executoriedade dos atos administrativos; a instituição de cláusulas exorbitantes nos contratos administrativos; a possibilidade de revogar os próprios atos inconvenientes e inoportunos; a previsão dos institutos da desapropriação e da requisição, dentre tantas outras.

Note-se que tais prerrogativas existem apenas e tão somente quando o que se persegue é o interesse público. Neste sentido, destaca Celso Antônio Bandeira de Mello:

as prerrogativas que nesta via exprimem tal supremacia [ou, para nós, preponderância] não são manejáveis ao sabor da Administração (...) os "poderes" administrativos - na realidade, deveres-poderes - só existirão - e, portanto, só poderão ser validamente exercidos - na extensão e intensidade proporcionais ao que seja irrecusavelmente requerido para o atendimento do escopo legal a que estão vinculados. Todo excesso, em qualquer sentido, é extravasamento de sua configuração jurídica. É, afinal, extralimitação da competência (nome que se dá, na esfera pública, aos "poderes” de quem titulariza função). É abuso, ou seja, uso além do permitido, e, como tal, comportamento inválido que o Judiciário deve fulminar a requerimento do interessado. $^{117}$

137), há de ser compreendido como o que pertine "à sociedade como um todo e só ele pode ser validamente objetivado, pois este é o interesse que a lei consagra e entrega à compita do Estado como representante do corpo social." Também é conhecido como interesse primário, para contrapor-se ao interesse secundário, que é aquele que "atina tão-só ao aparelho estatal enquanto entidade personalizada". (MELLO, Celso Antônio Bandeira de. Curso de Direito Administrativo. 27. ${ }^{\text {a }}$ ed. São Paulo: Malheiros Editores, 2010, p. 46).

${ }^{117}$ Ibidem, pp. 97 e 99. 
Resta claro perceber que o grande desiderato da posição privilegiada da Administração em relação aos particulares é a busca do interesse público e somente dele: qualquer atuação estatal pautada em tais prerrogativas que busque outro fim, distinto deste, viola de morte o primado da preponderância do interesse público e merece ser desfeita, sendo inclusive passível de indenização.

Diógenes Gasparini pondera, em sentido conforme:

A aplicabilidade desse princípio, por certo, não significa o total desrespeito ao interesse privado, já que a Administração deve obediência ao direito adquirido, à coisa julgada e ao ato jurídico perfeito, consoante prescreve a Lei Maior da República (art. 5. ${ }^{\circ}$, XXXVI). De sorte que os interesses patrimoniais afetados pela prevalência do interesse público devem ser indenizados cabalmente. ${ }^{118}$

Razão assiste à Odete Medauar, para quem à Administração Pública "cabe realizar a ponderação dos interesses presentes numa determinada circunstância, para que não ocorra sacrifício a priori de nenhum interesse", razão pela qual se afirma ter essa função o objetivo de buscar a "compatibilidade ou conciliação dos interesses, com a minimização de sacrifícios." 119

Significa dizer que a posição privilegiada da Administração - de 'supremacia' - confere-lhe prerrogativas para buscar e alcançar o interesse público, o que, porém, não poderá significar qualquer suposição quanto a uma virtual autonomia ou liberdade da Administração Pública similar ou de qualquer modo assimilável àquela de que dispõem os particulares.

${ }^{118}$ GASPARINI, Diógenes. Direito Administrativo. 11. a ed. São Paulo: Saraiva, 2006, p. 18. Celso Antônio Bandeira de Mello tem opinião similar, que merece ser aqui reproduzida: "Em face do exposto, fácil é ver-se que as prerrogativas inerentes à supremacia do interesse público sobre o interesse privado só podem ser manejadas legitimamente para o alcance de interesses públicos; não para satisfazer apenas interesses ou conveniências tão-só do aparelho estatal e muito menos dos agentes governamentais." (MELLO, Celso Antônio Bandeira de. Curso de Direito Administrativo. 27. ${ }^{\text {a }}$ ed. São Paulo: Malheiros Editores, 2010, item 19, p. 22).

${ }^{119}$ MEDAUAR, Odete. Direito Administrativo Moderno, 11. ${ }^{\text {a }}$ ed. rev., atual. e ampl. São Paulo: Revista dos Tribunais, 2007, p. 128. 
Como em outra passagem já se sublinhou, a Administração está adstrita à satisfação dos interesses da coletividade e os poderes que detém neste âmbito são, exclusivamente, para o fiel e estrito cumprimento e alcance de tais finalidades. A atividade administrativa não apenas requer um agir que não se oponha à lei, mas, mais do que isso, um agir nos estritos termos do que lhe autoriza a lei.

É por isso que se diz, com inteiro acerto, não haver espaço para a liberdade pessoal na Administração Pública. ${ }^{120}$ Isso porque a Administração Pública age nos estritos termos da lei, consoante o princípio da legalidade, adiante verificado. Ao administrador público não é facultada a autonomia da vontade, como ocorre nas relações envolvendo particulares. Daí porque a atuação da Administração é totalmente adstrita à lei, não cabendo ao administrador agir sem previsão legal, ao contrário do que ocorre nas relações reguladas pelo Direito Privado, onde o particular pode fazer tudo o que a lei não vedar.

Nessa toada, enquanto o particular não será "obrigado a fazer ou deixar de fazer alguma coisa, senão em virtude de lei"121, ao administrador público resta agir nos estritos termos da lei, tão somente quando e se houver previsão legal. Vigora, pois, no âmbito do direito privado o princípio da autonomia da vontade ${ }^{122-123}$, conforme as lições de Diogo de Figueiredo Moreira Neto:

\footnotetext{
${ }^{120}$ MEIRELLES, Hely Lopes. Direito Administrativo Brasileiro. 29. a ed. São Paulo: Malheiros Editores, 2004, p. 57.

${ }^{121}$ Nos termos do artigo $5 .^{\circ}$, II, CF, que dispõe sobre o princípio da legalidade nas relações entre particulares.

122 A autonomia da vontade, no Direito Privado, há muito vem sendo mitigada pela jurisprudência e também no plano legislativo, haja vista a previsão contida no Código de Defesa do Consumidor, que desde 1990 estabelece que os direitos ali previstos não podem ser afastados, nem mesmo por concordância expressa do consumidor. Com o advento do Código Civil de 2002, a autonomia da vontade foi, definitivamente, relativizada pela lei, a qual outrora era absoluta. O pacta sunt servanda dá lugar à rebus sic stantibus, consoante se extrai das lições da professora Maria Angélica Benetti Araújo: "Se até então era permitido às partes evitar todos os riscos futuros, porque lhes eram asseguradas a imutabilidade das prestações avençadas e a manutenção do contractus independentemente de fatos imprevistos que alterassem sobremodo a
} 
Se (...) no Direito Privado, prevalece o princípio da liberdade, que reconhece aos indivíduos a autonomia da vontade, atuando a lei como um limite da ação, no Direito Público, ao revés, não existe qualquer liberdade no agir do Estado, atuando a lei como seu único e próprio fundamento de ação. ${ }^{124}$

O princípio da indisponibilidade do interesse público, a seu turno, representa evidente limitação às prerrogativas e poderes da Administração Pública na persecução do interesse público. Em última análise, representa verdadeiro freio ao supracitado princípio da preponderância do interesse público, razão pela qual tais princípios são vistos como complemento um do outro. ${ }^{125}$

equação contratual, uma investigação minuciosa demonstra que, em lugar desta perenidade, instituiu-se a flexibilidade do contrato. Relativamente interpretado há de ser o princípio pacta sunt servanda diante da coexistência da cláusula implícita rebus sic stantibus, por meio da qual é possível revisar ou resolver o contrato em hipótese de transformação imprevisível e substancial na situação das partes" (ARAÚJO, Maria Angélica Benetti. Autonomia da vontade no direito contratual. Revista de Direito Privado, São Paulo, n. 27, Revista dos Tribunais, jul./set. 2006, p. 2).

${ }^{123}$ O Código Civil de 1916 era pautado por uma visão individualista - tendência, aliás, do Direito à época. O Direito contemporâneo é pautado pela visão do coletivo, valorizando a ética, a boa-fé, a função social, valores expressamente abrigados pelo Código Civil de 2002, positivando princípios como eticidade, socialidade e operabilidade. Ver, por todos, as lições de ARRUDA ALVIM, José Manoel de. Comentários ao Código Civil Brasileiro - Do Direito das Coisas, Volume XI - Tomo I - Livro Introdutório. Coord. Arruda Alvim e Thereza Alvim, Rio de Janeiro: GEN/Forense, 2009.

${ }^{124}$ MOREIRA NETO, Diogo de Figueiredo. Curso de Direito Administrativo. 14. ${ }^{\mathrm{a}}$ ed. Rio de Janeiro: Forense, 2005, p. 81.

${ }^{125}$ Nas palavras de Celso Antônio Bandeira de Mello, "Onde há função, pelo contrário, não há autonomia da vontade, nem a liberdade em que se expressa, nem a autodeterminação da finalidade a ser buscada, nem a procura de interesses próprios, pessoais. Há adstrição a uma finalidade previamente estabelecida, e, no caso de função pública, há submissão da vontade ao escopo pré-traçado na Constituição ou na lei e há o dever de cem curar um interesse alheio que, no caso, é o interesse público; vale dizer, na coletividade como um todo, e não na entidade governamental em si mesma considerada." (MELLO, Celso Antônio Bandeira de. Curso de Direito Administrativo. 27. a ed. São Paulo: Malheiros Editores, 2010, p. 98). O mesmo autor arremata, com precisão: "A indisponibilidade do interesse público significa que, sendo interesses qualificados como próprios da coletividade - internos ao setor público -, não se encontram à livre disposição de quem quer que seja, por inapropriáveis. O próprio órgão administrativo que os representa não tem disponibilidade sobre eles, no sentido de que lhe incumbe apenas curá-los - o que é também um dever - na estrita conformidade do que predispuser a intentio legis. (...) Em suma, o necessário - parece-nos - é encarecer que na administração dos bens e dos interesses não se acham entregues à livre disposição da vontade do administrador. Antes, para este, coloca-se a obrigação, o dever de curá-los nos termos da finalidade a que estão adstritos. É a ordem legal que dispõe sobre ela. Relembre-se que a 
A Administração Pública, estando submetida aos rigores e ao estrito cumprimento da lei, obriga-se ao cumprimento do bem estar da coletividade. Ora, em sendo assim, não pertence ao administrador a decisão pela defesa do interesse coletivo (justamente por ser indisponível - porque de todos, da coletividade - o bem ou interesse perseguido pela Administração); não lhe é dado decidir se age ou não em busca do bem da coletividade. Neste sentido, são as ponderações de Celso Antônio Bandeira de Mello, para quem

a Administração Pública está, por lei, adstrita ao cumprimento de certas finalidades, sendo-lhe obrigatório objetivá-las para colimar interesse de outrem: o da coletividade. É em nome do interesse público - o do corpo social - que tem de agir, fazendo-o na conformidade da intentio legis. Portanto, exerce 'função', instituto como visto - que se traduz na ideia de indeclinável atrelamento a um fim preestabelecido e que deve ser atendido para benefício de um terceiro. É situação oposta à autonomia da vontade, típica do Direito Privado. De regra, neste último alguém busca, em proveito próprio, os interesses que lhe apetecem, fazendo-o, pois, com plena liberdade, contanto que não viole alguma lei. ${ }^{126}$

Como visto, o primado da indisponibilidade do interesse público retira do administrador as faculdades próprias de quem possui o domínio de certa coisa, como, de fato, é regra assente e universal a de que a ninguém é dado dispor daquilo que não lhe pertence.

O administrador público, neste passo, não dispõe livremente dos interesses públicos a ele confiados, o que dá aos poderes que a Administração Pública assume o caráter de "poder-dever", como destaca Maria Sylvia Di Pietro. Diz referida autora: "são poderes que ela não pode deixar de exercer, sob

Administração não titulariza interesses públicos. O titular deles é o Estado, que, em certa esfera, os protege e exercita através da função administrativa, mediante o conjunto de órgãos (chamados administração, em sentido subjetivo ou orgânico), veículos da vontade estatal consagrada em lei." (MELLO, Celso Antônio Bandeira de. Curso de Direito Administrativo. 27. ${ }^{a}$ ed. São Paulo: Malheiros Editores, 2010, pp. 73-74).

${ }^{126}$ Ibidem, p. 98. 
pena de responder pela omissão...". ${ }^{27}$ E prossegue: “Cada vez que ela se omite no exercício de seus poderes, é o interesse público que está sendo prejudicado". 128

Também nesse sentido, pondera Diógenes Gasparini, ao tratar do princípio ora sob análise. Para o autor, "não se acham, segundo esse princípio, os bens, direitos, interesses e serviços públicos à disposição dos órgãos públicos [ou agentes públicos]"129. A tais órgãos ou agentes compete apenas a tarefa de curar tais bens ou direitos, na condição de meros gestores da coisa pública. E arremata: "Aqueles e este não são seus senhores ou seus donos, cabendo-lhes por isso tão-só o dever de guardá-los e aprimorá-los para a finalidade a que estão vinculados." 130

O princípio da indisponibilidade do interesse público, portanto, sela a ideia de que ao administrador público não é permitido dispor livremente do interesse coletivo, uma vez que não representa interesses próprios ou particulares. Assim, no desempenho da função pública que lhe é peculiar, deve agir sempre segundo os estritos limites impostos pela lei. ${ }^{131}$

${ }^{127}$ DI PIETRO, Maria Sylvia Zanella. Direito Administrativo. 13. a ed. São Paulo: Atlas, 2001, p. 70.

${ }^{128}$ Ibidem, mesma página.

${ }^{129}$ GASPARINI, Diógenes. Direito Administrativo. 11. a ed. São Paulo: Saraiva, 2006, p. 16.

${ }^{130}$ Ibidem, mesma página.

131 Neste sentido, aplicando o postulado, o Superior Tribunal de Justiça já decidiu: "PROCESSUAL CIVIL. ADMINISTRATIVO. AÇÃO DE INDENIZAÇÃO. COMPANHIA NACIONAL DE ABASTECIMENTO (CONAB). SAFRA DE ALGODÃO. CLASSIFICAÇÃO DO PRODUTO APONTADA COMO FRAUDULENTA EM AÇÕES DE IMPROBIDADE ADMINISTRATIVA. DESNECESSIDADE DE INTIMAÇÃO DO MINISTÉRIO PÚBLICO PARA TODOS OS ATOS DO PROCESSO. 1. A exegese do disposto no art. 82, III, do CPC, impõe a distinção jus-filosófica entre o interesse público primário e o interesse da administração, cognominado "interesse público secundário". (Lições de Carnelutti, Renato Alessi, Celso Antônio Bandeira de Mello e Min. Eros Roberto Grau). 2. O Estado, quando atestada a sua responsabilidade, revela-se tendente ao adimplemento da correspectiva indenização, coloca-se na posição de atendimento ao "interesse público". Ao revés, quando visa a evadir-se de sua responsabilidade no afã de minimizar os seus prejuízos patrimoniais, persegue nítido interesse secundário, subjetivamente pertinente ao aparelho estatal em subtrair-se de despesas, engendrando locupletamento à custa do dano alheio. 3. Deveras, é assente na doutrina e na jurisprudência que indisponível é o interesse público, e não o interesse da administração. Nessa última hipótese, não é necessária a atuação do Parquet no mister de custos legis, máxime porque a entidade pública empreende a sua defesa através de corpo 
Em suma, se a finalidade da Administração no trato da coisa pública é a defesa de interesses próprios da coletividade, refugindo, assim, da esfera de domínio do administrador público, então é cediço que este último não possui a capacidade de livre disposição dos bens que administra, que, aliás, são impenhoráveis, intransferíveis, inalienáveis, enfim, indisponíveis.

Com efeito, uma vez que a Administração Pública encontra-se submetida à obediência estrita aos termos da lei, a obrigatoriedade do desempenho da atividade pública, noção intrinsecamente associada ao princípio da continuidade, como se verá adiante - é princípio que se impõe, reconhecido e visualizado como projeção dos princípios da legalidade e da indisponibilidade do interesse público. Traduz-se na noção de um "dever" em que se encontra a Administração, relativamente à lei. ${ }^{132}$

próprio de profissionais da advocacia da União. Precedentes jurisprudenciais que se reforçam, na medida em que a atuação do Ministério Público não é exigível em várias ações movidas contra a administração, como, v.g., sói ocorrer, com a ação de desapropriação prevista no Decreto-lei n.3.365/41 (Lei de Desapropriação). 4. In genere, as ações que visam ao ressarcimento pecuniário contêm interesses disponíveis das partes, não necessitando, portanto, de um órgão a fiscalizar a boa aplicação das leis em prol da defesa da sociedade. 5. In casu, versam os autos originariamente Ação de Indenização ajuizada pela Companhia Nacional de Abastecimento - CONAB em face do Estado de Goiás e de agente público, objetivando a condenação solidária dos demandados ao ressarcimento dos prejuízos advindos de supostas irregularidades na classificação de produto agrícola (algodão em pluma) adquirido do primeiro réu e classificado pelo segundo réu referente à safra 97/98. 6. Ademais, a suposta nulidade somente pode ser decretada se comprovado o prejuízo para os fins de justiça do processo, em razão do Princípio de que não há nulidade sem prejuízo ('pas des nullités sans grief'). 7. Por fim, cumpre registrar, o interesse público justificador da intervenção do Ministério Público, nos moldes do art. 82, III, do CPC, não se confunde com interesse patrimonial da Fazenda Pública ou mera presença de pessoa jurídica de Direito Público na lide. Precedentes do STJ:REsp 465580/RS, Relator Min. Castro Meira, DJ de 08.05.2006; REsp 466500/RS, Relatora Min. Denise Arruda, DJ de 03.04.2006; REsp 466500/RS, Relatora Min. Denise Arruda, DJ de 03.04.2006 e REsp 490726/SC, Relator Min. Teori Zavascki, DJ de 21.03.2005. 8. Recurso Especial provido." (BRASIL. Superior Tribunal de Justiça. REsp n. ${ }^{\circ}$ 115306/GO. STJ. Primeira Turma. Rel. Min. Luiz Fux. Julgamento em 29/03/2010. Disponível em http://www.stj.jus.br. Acesso em 02/12/2010).

${ }^{132}$ MELLO, Celso Antônio Bandeira de. Curso de Direito Administrativo. 27. a ed. São Paulo: Malheiros Editores, 2010, pp. 99-100. 


\subsection{Princípios da proporcionalidade e da razoabilidade}

O chamado 'princípio' da proporcionalidade ${ }^{133}$ manifesta-se, no espectro do regime jurídico-administrativo, como preceito que obriga a Administração Pública a alcançar o equilíbrio necessário entre interesses conflitantes: os direitos dos administrados e as prerrogativas da Administração, em uma constante análise da relação meio-fim.

Assim, tal princípio exige que as restrições aos direitos fundamentais dos administrados estejam rigorosamente previstas em lei, sendo, para tanto, adequadas aos fins a que se dirigem e vinculadas à proteção de um interesse coletivo.

De acordo com Daniel Sarmento, o princípio da proporcionalidade é o instrumento da ponderação, sendo visualizada ou manifestada em seu tríplice aspecto: adequação (ou seja, um nexo de pertinência), necessidade e proporcionalidade em sentido estrito (esta, a exemplo do que se passa na adequação, visualizada na efetiva proporcionalidade entre a medida tomada e o resultado almejado). Com efeito, segundo o autor, a proporcionalidade guiará o caminho lógico a ser percorrido pelo agente público

\footnotetext{
${ }^{133}$ Humberto Ávila prefere a expressão postulado, na medida em que não reconhece na proporcionalidade o status de um princípio. Para ele "sua descrição abstrata não permite uma concretização em princípio gradual, pois a sua estrutura trifásica consiste na única possibilidade de sua aplicação; a aplicação dessa estrutura independe das possibilidades fáticas e normativas, já que o seu conteúdo normativo é neutro relativamente ao contexto fático; sua abstrata explicação exclui, em princípio, a sua aptidão e necessidade de ponderação, pois o seu conteúdo não irá ser modificado no entrechoque com outros princípios. Não bastasse, a proporcionalidade não determina as razões a sua aplicação atribuirá um peso, mas apenas uma estrutura formal de aplicação de outros princípios." (ÁVILA, Humberto Bergmann, A distinção entre princípios e regras e a redefinição do dever de proporcionalidade, Revista de Direito Administrativo 215, Rio de Janeiro: Renovar, p. 169).
} 
ou administrador, com vistas à máxima realização dos interesses em jogo e a causação do menor sacrifício possível. ${ }^{134}$

Em outras palavras, a restrição imposta a um desses interesses em jogo, em um dado caso de (aparente) conflito de princípios constitucionais, só se justificará na exata medida em que: (1) mostrar-se apta a garantir a sobrevivência do interesse contraposto; (2) não houver solução menos gravosa e (3) o benefício atingido com a restrição a um dos interesses deve necessariamente compensar o grau de sacrifício imposto ao interesse contraposto. $^{135}$

Harmut Maurer atribui ao princípio da proporcionalidade o predicado de constituir verdadeiro 'princípio geral do direito administrativo'. ${ }^{136}$

Em diversas ocasiões o Supremo Tribunal Federal manifestou-se sobre o tema, aplicando a técnica da ponderação, "instrumentalizada através do postulado da proporcionalidade", como destaca com precisão Gustavo Binenbojm. ${ }^{137} \mathrm{E}$ em uma dessas oportunidades, de maneira absolutamente didática, consignou, em voto da lavra do Min. Gilmar Mendes, que

o princípio da proporcionalidade representa um método geral para que a solução de conflitos entre princípios, isto é, um conflito entre normas que, ao contrário do conflito entre regras, é resolvido não pela revogação ou redução teleológica de uma das normas

\footnotetext{
${ }^{134}$ SARMENTO, Daniel. A ponderação de interesses na Constituição Federal. Rio de Janeiro: Lúmen Juris, 2002, p. 96.

${ }^{135}$ Ibidem, mesma página.

${ }^{136}$ MAURER, Hartmut. Direito Administrativo Geral. 14. ${ }^{\text {a }}$ ed. rev. e comp. Barueri: Manole, 2006, p. 79. Para ele: "O princípio da proporcionalidade (...) é reconhecido desde há muito e, com isso, solidificado jurídico-costumeiramente, mas ele também resulta da Lei Fundamental (de direitos fundamentais particulares, artigo 19 II da Lei Fundamental e do princípio do estado de direito), ele, ademais, é suscetível de generalização em determinados campos do direito, por exemplo, no direito policial, está regulado jurídico-positivamente e ele pode, por fim, ser derivado dos 'princípios jurídicos'. (Ibidem, pp. 79-80).

${ }^{137}$ BINENBOJM, Gustavo. A supremacia do interesse público sobre o particular ao dever de proporcionalidade: um novo paradigma para o direito administrativo. Revista de Direito Administrativo, v. 239. Rio de Janeiro: Renovar, jan./mar. 2005, p. 21.
} 
conflitantes nem pela explicitação de distinto campo de aplicação entre as normas, mas antes e tão somente pela ponderação do peso relativo de cada uma das normas.

\section{(...)}

Tal como já sustentei em estudo sobre a proporcionalidade na jurisprudência do Supremo Tribunal Federal (...), há de perquirir-se, na aplicação do princípio da proporcionalidade, se em face do conflito entre dois bens constitucionais contrapostos, $\mathrm{o}$ ato impugnado afigura-se adequado (isto é, apto para produzir o resultado desejado), necessário (isto é, insubstituível por outro meio menos gravoso e igualmente eficaz) e proporcional em sentido estrito (ou seja, se estabelece uma relação ponderada entre o grau de restrição de um princípio e o grau de realização do princípio contraposto). ${ }^{138}$

Em suma, a proporcionalidade revela-se na constante busca pelo "equilíbrio" e, portanto, manifesta-se necessário exame feito pela Administração Pública entre os interesses individuais e os coletivos, à vista dos três critérios acima examinados: necessidade, adequação e proporcionalidade em sentido estrito, exigindo um juízo de ponderação que deve analisar a exigibilidade do comportamento administrativo para se alcançar o interesse público, a adequação de tal comportamento ao fim pretendido e a relação entre as vantagens e desvantagens que o ato poderá gerar.

Assim, dessa análise deverá surgir a medida mais apropriada para a realização do interesse público de acordo com o fim pretendido, sem que ao particular experimente desvantagem excessiva. Em face do exposto apura-se, com facilidade, a íntima relação entre o princípio da proporcionalidade e o da preponderância dos interesses públicos sobre os particulares, examinado linhas acima.

\footnotetext{
${ }^{138}$ BINENBOJM, Gustavo. A supremacia do interesse público sobre o particular ao dever de proporcionalidade: um novo paradigma para o direito administrativo. Revista de Direito Administrativo, v. 239. Rio de Janeiro: Renovar, jan/mar. 2005, pp. 21-22, citando acórdão da lavra do Min. Gilmar Mendes no julgamento da Intervenção Federal 2.257-6/São Paulo.
} 
Registre-se, de outro lado, que dentro do significado do princípio da proporcionalidade reside, como verdadeira faceta, o da razoabilidade. Como se viu, aquele consiste "no dever de não serem impostas, aos indivíduos em geral, obrigações, restrições ou sanções em medida superior àquela estritamente

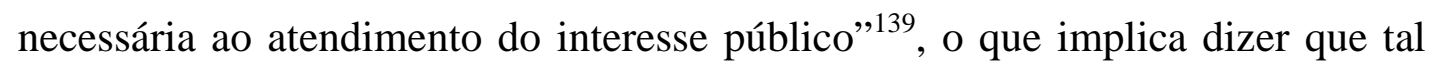
atuação há de se estribar no critério de uma "razoável adequação dos meios aos fins". 140

Diz-se, assim, que a Administração Pública tem o dever de agir de forma razoável, dentro de um padrão normal de comportamento, sem excessos. Essa é a noção trazida pelo princípio da razoabilidade, consoante se colhe da doutrina:

Sem dúvida, pode ser chamado de princípio da proibição de excesso, que, em última análise, objetiva aferir a compatibilidade entre os meios e os fins, de modo a evitar restrições desnecessárias ou abusivas por parte da Administração Pública, com lesão aos direitos fundamentais. ${ }^{141}$

Pois bem, o princípio da razoabilidade não se encontra expressamente previsto na Constituição de 1988; sem embargo disso, a exemplo do princípio da proporcionalidade, goza de importância e prestígio equivalentes aos princípios expressamente enumerados.

O princípio da razoabilidade é princípio reconhecidamente informador do direito administrativo, "atuando como instrumento de controle do exercício, pela Administração, de discricionariedade". ${ }^{142}$

\footnotetext{
${ }^{139}$ MEDAUAR, Odete. Direito Administrativo Moderno, 11. ${ }^{\text {a }}$ ed. rev., atual. e ampl. São Paulo: Revista dos Tribunais, 2007, p. 128.

${ }^{140}$ Ibidem, mesma página.

${ }^{141}$ Cf. Direito Administrativo Brasileiro. 33. ${ }^{a}$ ed., São Paulo: Malheiros Editores, 2007, p. 93.

${ }^{142}$ GRAU, Eros Roberto. Suspensão do fornecimento de energia elétrica: constitucionalidade, Código do Consumidor, princípios e postulados normativos aplicativos da razoabilidade e da proporcionalidade, Revista Trimestral de Direito Público, v. 36, 2001, p. 146.
} 
A Administração Pública, no desempenho de sua função administrativa, deve obediência aos princípios da legalidade, impessoalidade, moralidade e publicidade, motivação, dentre outros, agindo sempre pautada nos ditames da razoabilidade. O princípio da razoabilidade, portanto, integra o ordenamento jurídico brasileiro na exata medida em que é pressuposto lógico da elaboração das leis e da própria atuação da Administração Pública.

Ora, a Administração Pública, ainda que no exercício de sua atividade discricionária, e ainda que na defesa dos interesses ditos "coletivos", tem o dever de agir segundo o senso comum do homem médio. Desta feita, toda vez que um ato se distancia dos ditames da razoabilidade, é possível afirmar que tal ato é ilegal e, portanto, carece de validade:

\begin{abstract}
A lei, ao conceder ao agente público o exercício da discricionariedade, não the reservou, em absoluto, qualquer poder para agir ao seu gosto, ao contrário, impôs-lhe o encargo de agir tomando a melhor providência à satisfação do interesse público a ser conseguido naquele momento. A lei, portanto, não lhe permite, sob pena de ilegalidade, qualquer conduta não desejada pela lei, que somente aceita as coerentes. Em suma: nada que esteja fora do razoável, do sensato, do normal, é permitido ao agente público, mesmo quando atua no exercício de competência discricionária. ${ }^{143}$
\end{abstract}

\title{
2.5 Princípio da eficiência
}

Examinemos, por derradeiro, o princípio da eficiência, introduzido expressamente na Constituição da República pela Emenda Constitucional n. ${ }^{\circ}$ 19/98 (Reforma Administrativa), mas que, muito antes, já podia ser depreendido

${ }^{143}$ GASPARINI, Diógenes. Direito Administrativo. 11. a ed. São Paulo: Saraiva, 2006, p. 22. 
do próprio sistema de princípios norteadores da Administração Pública. ${ }^{144}$ Registre-se que mesmo antes de seu acolhimento expresso no texto constitucional pela Reforma Administrativa o valor eficiência era reconhecido e abertamente assumido no plano da legislação infraconstitucional brasileira: assim, o Decreto 200/67, cujo art. 26, inc. II submetia a administração indireta à supervisão ministerial quanto à eficiência administrativa; a Lei de Concessões e Permissões (Lei n. ${ }^{\circ} 8.987 / 95$, arts. 6. ${ }^{\circ}, \S 1 .^{\circ}, 7^{\circ}$ e 31 ) e, igualmente, o próprio Código de Defesa do Consumidor (art. 6. ${ }^{\circ}$, inc. X e, em particular, o art. 22, adiante examinado). ${ }^{145}$

Para o direito administrativo, o princípio da eficiência significa que o agente público, no exercício da função administrativa, tem o dever de utilizar todos os meios de que dispõe para o cumprimento de suas obrigações de

${ }^{144}$ Em certa medida, o art. 74, inc. II, da CF, já se referia ao princípio, ao estabelecer que "os Poderes Legislativo, Executivo e Judiciário manterão, de forma integrada, sistema de controle interno com a finalidade de: (...) comprovar a legalidade e avaliar os resultados, quanto à eficácia e eficiência, da gestão orçamentária, financeira e patrimonial nos órgãos e entidades da Administração Federal, bem como da aplicação de recursos públicos por entidades de direito privado." Edilson Pereira Nobre Júnior ressalta a necessidade de se desfazer o equívoco de que a imposição de eficiência administrativa adveio com a EC 19/98. Para ele, diferentemente, a eficiência "precede, em muito, a mencionada reforma constitucional." E prossegue: "Prova insofismável disso é que Carvalho Simas, em escrito elaborado sob a égide da Constituição de 1969, punha em destaque a eficiência como um dos princípios norteadores da Administração Pública, evocando o ensinamento da doutrina itálica do dever de boa administração. Foram suas palavras: "A ação dos administradores deverá apresentar, como resultado, uma efetiva satisfação das necessidades coletivas. No conceito apresentado de 'função administrativa' está implícito o real atendimento dessas necessidades, o que só poderá ser alcançado através de uma atuação adequada e positiva dos órgãos e agentes do Governo. (...) Ao lado da estrita observância dos princípios da legalidade e da moralidade, a Administração Pública não poderá ser ineficiente. É inaceitável que sua atuação apresente, como resultado, a falta de atendimento àquelas solicitações gerais, que está obrigada a satisfazer. Os agentes e órgão do Poder Público têm o dever de bem servir, dentro da moralidade administrativa, mas diligenciando para apresentar, pelo emprego de processos e técnicas apropriadas, um saldo proveitoso" (Manual elementar de direito administrativo. 3. ${ }^{\text {a }}$ ed. Rio de Janeiro: Liber Juris. p. 205)." (NOBRE JUNIOR, Edilson Pereira. Administração pública e o princípio constitucional da eficiência. Revista de Direito Administrativo, v. 241. Rio de Janeiro: Renovar, jan./mar. 2005, p. 224). De fato, Hely Lopes Meirelles em texto escrito anteriormente ao texto constitucional de 1988 já aludia ao dever de eficiência a que a Administração encontrava-se submetida. (Ibidem, mesma página).

${ }^{145}$ A Lei Orgânica do Município de São Paulo, datada de 04/04/1990, em art. 123, parágrafo único, também faz expressa menção ao termo, consignando: "usuário fica garantido serviço público compatível com sua dignidade humana, prestado com eficiência, regularidade, pontualidade, uniformidade, conforto e segurança, sem distinção de qualquer espécie". 
forma a obter o maior rendimento possível. Diógenes Gasparini, a respeito, assevera:

Conhecido entre os italianos como "dever de boa administração", o princípio da eficiência impõe à Administração Pública direta e indireta a obrigação de realizar suas atribuições com rapidez, perfeição e rendimento, além, por certo, de observar outras regras, a exemplo do princípio da legalidade. Pela EC n. ${ }^{\circ}$ 19/98, que o acrescentou ao rol dos consignados no art. 37, esse princípio ganhou status constitucional. ${ }^{146}$

O princípio da eficiência obriga a Administração Pública na realização do bem comum, bem como a todos os seus agentes, a se utilizarem de imparcialidade, transparência, eficácia, publicidade, rapidez, enfim, de todos os instrumentos reservados pela lei, com o fim único de alcançar o melhor aproveitamento dos recursos públicos em prol da prestação dos serviços à população. $^{147}$

Edilson Pereira Nobre Júnior, em trabalho dedicado ao tema registra, a propósito, que a "exigência de que a atividade administrativa seja influenciada pela eficiência não é estranha a outros ordenamentos”. E prossegue, dizendo: "Exemplo interessante se centra, de início, na Constituição italiana de 1947, cujo art. 97.1 proclama: 'Os órgãos públicos são organizados segundo disposições de lei, de modo que sejam assegurados o bom andamento e a imparcialidade da administração." 148

\footnotetext{
${ }^{146}$ GASPARINI, Diógenes. Direito Administrativo. 11. a ed. São Paulo: Saraiva, 2006, p. 19.

147 Em interessante e didática passagem de acórdão proferido pelo TJSP (Agravo de Instrumento n. ${ }^{\circ}$ 7.154.769-4), fazendo expressa menção ao art. 22 do Código de Defesa do Consumidor, a 14. ${ }^{\mathrm{a}}$ Câmara de Direito Privado daquele Tribunal consignou: "Conforme disciplina o princípio da eficiência, o agente público deve realizar suas atribuições com presteza, perfeição e rendimento funcional." (BRASIL. Tribunal de Justiça do Estado de São

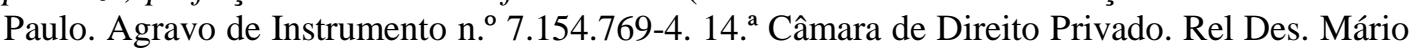
de Oliveira. Julgamento em 22/08/2007. v.u. - os grifos são nossos).

${ }^{148}$ NOBRE JUNIOR, Edilson Pereira. Administração pública e o princípio constitucional da eficiência. Revista de Direito Administrativo, v. 241. Rio de Janeiro: Renovar, jan./mar. 2005, p. 212.
} 
Reconhece-se também na Argentina disposição semelhante constante da Constituição da Nação Argentina. Segundo Roberto Dromi - que emprega como equivalentes as expressões eficácia e eficiência - tal preceito foi erigido como um dos novos valores do direito contemporâneo, a partir da premissa de que a sociedade repudia veementemente o retorno a um Estado ineficiente, sendo assumido, no texto constitucional daquele país, em vários dispositivos (ora sob o signo da eficácia, ora da eficiência). ${ }^{149}$

De maneira análoga, na Constituição italiana está textualmente previsto como padrão fundamental da ação administrativa o 'bom funcionamento da Administração'. Diz o art. 97 do texto constitucional italiano que "os cargos públicos se organizarão segundos os preceitos da lei de tal modo a se garantir o bom funcionamento e a imparcialidade da Administração."

Carmela Leone sustenta que se o atuar da Administração Pública deve ser dirigido ao atendimento das exigências presentes na sociedade e canonizadas pelas normas, por isso necessita predispor instrumentos organizativos e realizar uma atividade idônea a obter os resultados programados, por intermédio daquela que foi definida como uma "rápida regulação dos interesses". ${ }^{151}$

Entre nós, o princípio da eficiência "determina que a Administração deve agir, de modo rápido e preciso, para produzir resultados que satisfaçam as necessidades da população", segundo os dizeres de Odete Medauar" ${ }^{152}$, que prossegue: "Eficiência contrapõe-se a lentidão, a descaso, a

\footnotetext{
${ }^{149}$ DROMI, Roberto. Derecho administrativo. Buenos Aires: Cuidad Argentina, 1996, p. 26.

150 Tradução livre do autor do art. 97, da Constituição italiana. Ver, por todos, LEONE, Carmela. Il principio di continuità dell'azione amministrativa. Milão: Giuffrè, 2007, especialmente p. 129.

${ }^{151}$ Ibidem, p. 131 (tradução livre do autor).

${ }^{152}$ MEDAUAR, Odete. Direito Administrativo Moderno. 11. ${ }^{\text {a }}$ ed. rev., atual. e ampl. São Paulo: Revista dos Tribunais, 2006, p. 131. Em outra obra, a autora arremata: "A eficiência tornou-se uma das ideias-força das reformas administrativas realizadas em inúmeros países... O vocábulo eficiência liga-se à ideia de ação que leve à ocorrência de resultados de modo rápido e preciso; significa obter o máximo de resultado de um programa a ser realizado, como expressão de
} 
negligência, a omissão - características habituais da Administração Pública brasileira, com raras exceções." 153

O reconhecimento do assento constitucional do princípio da eficiência - antes mesmo da inclusão expressa no texto constitucional pela EC 19/98 - não pode lhe dar, porém, conotação de valor absoluto, nem mesmo permitir a sua sobreposição em relação aos demais cânones regentes da Administração Pública. Exatamente por essas razões é que não se pode sustentar, legitimamente, que em nome e por causa da eficiência o princípio da legalidade poderia ser de algum modo mitigado ou sacrificado.

Para Odete Medauar, "os dois princípios constitucionais da Administração devem conciliar-se, buscando esta atuar com eficiência, dentro da legalidade" ${ }^{\text {154 }}$, opinião compartilhada por Celso Antônio Bandeira de Mello, ${ }^{155} \mathrm{e}$ Edilson Pereira Nobre Júnior. ${ }^{156}$

A defesa do bem comum de forma eficaz é finalidade básica da Administração Pública que deita raízes na própria razão de existência do Estado.

produtividade no exercício de atribuições." (MEDAUAR, Odete. O Direito Administrativo em Evolução. 2. rev. reb atual. e ampl. São Paulo: Revista dos Tribunais, 2003, p. 242)

${ }^{153}$ MEDAUAR, Odete. Direito Administrativo Moderno. 11. a ed. rev., atual. e ampl. São Paulo: Revista dos Tribunais, 2006, p. 131. Em outra obra, a autora arremata: "A eficiência tornou-se uma das ideias-força das reformas administrativas realizadas em inúmeros países... O vocábulo eficiência liga-se à ideia de ação que leve à ocorrência de resultados de modo rápido e preciso; significa obter o máximo de resultado de um programa a ser realizado, como expressão de produtividade no exercício de atribuições." (MEDAUAR, Odete. O Direito Administrativo em Evolução. 2. ${ }^{a}$ ed. São Paulo: Revista dos Tribunais, 2003, p. 242)

${ }^{154}$ MEDAUAR, Odete. Direito Administrativo Moderno. 11. ${ }^{\text {a }}$ ed. rev., atual. e ampl. São Paulo: Revista dos Tribunais, 2006, p. 132.

155 São suas as palavras: "A Constituição se refere, no art. 37, ao princípio da eficiência. Advirta-se que tal princípio não pode ser concebido (entre nós nunca é demais fazer ressalvas óbvias) senão na intimidade do princípio da legalidade, pois jamais uma suposta busca de eficiência justificaria a postergação daquele que é o dever administrativo por excelência." (MELlo, Celso Antônio Bandeira. Curso de Direito Administrativo. 27. a ed. São Paulo: Malheiros Editores, 2010, pp. 122-123). No mesmo sentido: "Vale dizer que a eficiência é princípio que se soma aos demais princípios impostos à Administração, não podendo sobreporse a nenhum deles, especialmente ao da legalidade, sob pena de sérios riscos à segurança jurídica e ao próprio Estado de Direito." (DI PIETRO, Maria Sylvia Zanella. Direito Administrativo. 20. ${ }^{\text {e }}$ d. São Paulo: Atlas, 2007, p. 76)

156 NOBRE JUNIOR, Edilson Pereira. Administração pública e o princípio constitucional da eficiência. Revista de Direito Administrativo, v. 241. Rio de Janeiro: Renovar, jan./mar. 2005, p. 240. 
Note-se que ser eficiente é requisito próprio da função exercida pelo administrador público, exatamente como descreve Maria Sylvia Zanella Di Pietro:

O princípio da eficiência apresenta, na realidade, dois aspectos: pode ser considerado em relação ao modo de atuação do agente público, do qual se espera o melhor desempenho possível de suas atribuições, para lograr os melhores resultados; e em relação ao modo de organizar, estruturar, disciplinar a Administração Pública, também com o mesmo objetivo de alcançar os melhores resultados na prestação do serviço público. ${ }^{157}$

Em última análise, reconhece-se, quer no Brasil, quer no plano do direito estrangeiro, um núcleo comum do princípio da eficiência, que revela a sua importância tanto para a Administração Pública quanto para os administrados, na exata medida em que demonstra a necessidade de aperfeiçoamento constante dos serviços e atividades públicas, primando, assim, pelo atendimento cada vez mais célere, simplificado e eficaz do interesse público.

${ }^{157}$ DI PIETRO, Maria Sylvia Zanella. Direito Administrativo. 20. a ed. São Paulo: Atlas, 2007, p. 83 . 


\section{PRINCÍPIO DA CONTINUIDADE DO SERVIÇO PÚBLICO: PRIMEIRA APRESENTAÇÃO}

\subsection{Princípio da continuidade e princípios guias do regime jurídico- administrativo}

Antes de precisar o conceito e delimitar o espectro de atuação do princípio da continuidade, devemos tecidas algumas considerações acerca da íntima relação que se estabelece entre o objeto de nosso estudo e outros princípios regentes do regime jurídico-administrativo.

Vimos que a atividade administrativa - e, portanto, o serviço público - submete-se a uma série de princípios de raízes constitucionais. Alguns desses princípios foram acolhidos expressamente no texto constitucional, mais precisamente no art. 37, da Constituição. Outros, conquanto não expressamente previstos em aludido preceito, são encontrados em outros textos da Constituição, havendo vários deles que estão implicados ou, melhor dizendo, emanam da própria estrutura do sistema constitucional e do Estado Democrático de Direito brasileiro.

No âmbito do direito administrativo - terreno e seara em que se encontra predominantemente submetida a Administração Pública - os princípios regentes assumem posição destacada: tratando-se de regime não codificado, a identificação, compreensão e delimitação de tais princípios (ao lado de outras regras) é que lhe confere unidade e identidade.

Mas não apenas.

Apuramos de igual forma que os princípios têm, por assim dizer, dupla função: atuam, em uma primeira perspectiva, como "regras de estrutura", quando destinados ao legislador; atuam, de outro lado, como "regras de 
comportamento", na medida em que valores e vetores que norteiam o seu intérprete, por ocasião de sua aplicação. ${ }^{158}$

Como também evidenciamos em passagens anteriores, se se pretende compreender e interpretar o direito administrativo - ou um braço dele, como no caso, já que nosso foco de atenção central é o princípio da continuidade do serviço público - o estudo, ainda que muito breve, de alguns dos mais significativos cânones sobre os quais se assenta o regime jurídicoadministrativo, é de fundamental valia.

Evidência maior da importância de uma visão mais abrangente, de molde a compreender outros princípios, resulta da posição do princípio da continuidade em nosso sistema: tratando-se de princípio não expressamente albergado no texto do art. 37, da CF, é, como se afirma em voz única, desdobramento ou projeção de outros. Daí a pertinência desse exame, ainda que bastante breve, no Capítulo 2, supra.

Carmela Leone, às voltas com a mesma reflexão - em torno da relação do princípio da continuidade relativamente a outros princípios guias do direito administrativo - registra a importância da distinção do princípio da continuidade de outros que devem informar a atividade administrativa, até para que se possa "superar a dúvida de que, no fundo, as exigências cobertas pelo princípio de continuidade já estariam sendo satisfeitas pelos outros princípios, tornando inútil a criação de mais padrão autônomo." ${ }^{159}$ Ao que conclui, enfim em opinião referendada por nós e a respeito da qual teceremos oportunas considerações adiante - que o princípio de continuidade tem, sim, "uma sua

\footnotetext{
${ }^{158}$ SCARTEZZINI, Ana Maria Goffi Flaquer. O princípio da continuidade do serviço público. São Paulo: Saraiva, 2006, p. 89.

${ }^{159}$ LEONE, Carmela. Il principio di continuità dell'azione amministrativa. Milão: Giuffrè, 2007, pp. 143-144.
} 
autonomia conceitual e uma sua utilidade prática que permitem à administração enriquecer os parâmetros jurídicos do seu agir."

O princípio da legalidade é, reconhecidamente, o mandamento nuclear que rege e há de inspirar todo o atuar da Administração Pública. Além de ter conformação algo diversa daquela que se proteja na esfera e no campo de atuação dos particulares, a legalidade (para a Administração, legalidade estrita) desdobra-se em diversos outros postulados informadores da atividade administrativa, os quais, por terem maior significado e impacto no objeto central deste trabalho, exigiram alguma atenção.

A partir dessa perspectiva, vimos que a estrutura básica do regime jurídico-administrativo assenta-se, fundamentalmente, em dois princípios basilares: ${ }^{161}$ o da preponderância ${ }^{162}$ do interesse público sobre o interesse privado e o da indisponibilidade pela Administração dos interesses públicos. Mas não apenas: outros princípios, de imenso significado, foram também considerados na exata medida em que impactam, com alguma força, no tema central deste trabalho e com ele se relacionam. Refere-se em particular aos princípios da obrigatoriedade do desempenho da atividade administrativa, da proporcionalidade e da razoabilidade, e da eficiência, princípios estes que, reconhecidamente, descendem da própria legalidade assegurada no multirreferido art. 37 , da CF.

A análise do tema proposto implementa-se, agora, com o exame da origem do princípio da continuidade, a partir de uma perspectiva maior, é dizer, reconhecendo-o como desdobramento da obrigatoriedade do desempenho da atividade administrativa.

${ }^{160}$ LEONE, Carmela. Il principio di continuità dell'azione amministrativa. Milão: Giuffrè, 2007, p. 147.

${ }^{161}$ Além, é claro, o da legalidade.

162 No Capítulo 2, supra, observamos a utilização corrente da expressão "Princípio da Supremacia do Interesse Público" pela doutrina maciça. Preferimos, porém, a expressão "preponderância", no lugar de supremacia, pelas razões que lá elencamos, às quais remetemos o leitor. 
Nos termos do quanto examinado linhas atrás, a obrigatoriedade do desempenho da atividade pública é princípio reconhecido e visualizado como projeção dos princípios da legalidade e da indisponibilidade do interesse público pela Administração.

Traduz-se, segundo autorizada doutrina, na noção de um "dever" em que se encontra a Administração relativamente à lei. ${ }^{163}$ Ora, precisamente em função da obrigatoriedade do desempenho da atividade administrativa a Administração Pública submete-se ao dever de continuidade de seu agir. De fato, na exata medida em que a Administração Pública é "curadora de determinados interesses que a lei define como públicos e considerando que a defesa, e prosseguimento deles, é, para ela, obrigatória, verdadeiro dever, a continuidade da atividade administrativa é princípio que se impõe e prevalece em quaisquer circunstâncias."164

Justamente em razão disso é que os agentes administrativos, submetidos a este mesmo 'dever' (o de zelar pelo interesse público), não podem deixar de seguir essa finalidade cogente, ${ }^{165}$ devendo fazê-lo de maneira contínua, ininterruptamente. É o que se afirma, em voz uníssona, no seio da doutrina: “Os serviços públicos não podem parar, porque não param os anseios da coletividade. Os desejos dos administrados são contínuos. Daí dizer-se que a atividade da Administração Pública é ininterrupta”. ${ }^{166}$

Sugere-se, pela incidência deste princípio, a ideia de um serviço regular cujo exercício, dentro das necessidades da coletividade e à vista de sua natureza, haverá de desenvolver-se sem interrupções.

${ }^{163}$ MELLO, Celso Antônio Bandeira. Curso de Direito Administrativo. 27. a ed. São Paulo: Malheiros Editores, 2010, p. 80.

${ }^{164}$ Ibidem p.81.

${ }^{165}$ Ibidem, p. 81.

${ }^{166}$ Cf. Direito Administrativo. 11. ${ }^{\text {a }}$ ed. São Paulo: Saraiva, 2006, p. 17. De fato, como pontua Ana Maria Goffi Flaquer Scartezzini: "Em relação à continuidade, de outra parte, existe a obrigatoriedade de quem presta o serviço; de nada valeria afirmar que o serviço deve ser regular e contínuo, se quem deve prestá-lo ou realizá-lo não estivesse 'obrigado' a fazê-lo." (SCARTEZZINI, Ana Maria Goffi Flaquer. O princípio da continuidade do serviço público. São Paulo: Malheiros Editores, 2006, p. 93). 
As afirmações até aqui feitas em torno da continuidade não podem permitir, entretanto, uma associação com a ideia de permanência. Até porque, nos termos do que bem frisa José Cretella Jr, "muitos deles são por natureza intermitentes, como, por exemplo, o serviço público eleitoral, o serviço das comissões de bolsas de estudos, mas significa que o serviço deve funcionar regularmente, isto é, de acordo com a natureza e conforme o que prescrevem os estatutos que os organizam.",167

Em última análise, o princípio da continuidade do serviço público está intimamente ligado a outro grande princípio informador do direito administrativo moderno: o princípio da indisponibilidade do interesse público. Ora, a razão de ser da previsão do princípio da continuidade do serviço público no ordenamento jurídico brasileiro reside exatamente na ideia de que o serviço público, como interesse indisponível que é, há de ser prestado de maneira contínua, sem interrupções.

Neste mesmo sentido pondera Diogo de Figueiredo Moreira Neto, aduzindo que as atividades do Estado-administrador, consideradas em conjunto, "se supõem legalmente definidas e a ele cometidas, por terem sido consideradas como necessárias à satisfação dos interesses públicos que lhe foram confiados"168, tornando-se, por tanto, “indisponíveis para seu ramo executivo". ${ }^{169}$ E prossegue, em outra interessante passagem:

Disso resulta que qualquer solução de continuidade que a Administração cause ou permita que se cause à regularidade dessas atividades fere a lei comitente, salvo se ela própria a tiver previsto. (...) A propósito, este princípio substantivo informa, de modo especial, a prestação de serviços públicos, assim entendidos aqueles

\footnotetext{
${ }^{167}$ CRETELLA JR, José. Tratado de Direito Administrativo, Rio de Janeiro: Forense, 1972, vol. 10 , p. 85.

${ }^{168}$ MOREIRA NETO, Diogo de Figueiredo. Curso de Direito Administrativo. 14. ${ }^{\text {a }}$ ed. Rio de Janeiro: Forense, 2005, p. 103.

${ }^{169}$ Ibidem, mesma página.
} 
cometidos por lei ao Estado para regulá-las ou, conforme o caso, para executá-las ou apenas superintender a sua execução. ${ }^{170}$

O princípio da continuidade relaciona-se, de igual forma, com o princípio da eficiência, e isso se dá de maneira bastante acentuada. Na exata medida em que o serviço público, antes de um conceito, constitui-se em um fato, uma de suas marcas fundamentais é o da continuidade, na perspectiva da exigência de um serviço prestado de maneira eficiente, "sob pena de prejudicar justamente o beneficiário, o destinatário para o qual o serviço foi criado." 171 Retomaremos esse ponto logo adiante, reconhecendo o princípio da continuidade como verdadeira faceta ou desdobramento da eficiência, afirmação que é inteiramente válida também para o direito italiano.

Sob outra perspectiva, identifica-se a íntima relação do princípio da continuidade com o da igualdade ou do tratamento equitativo dos usuários, visualizado na vedação a um tratamento discriminatório que venha a ser conferida aos usuários dos serviços públicos. ${ }^{172}$

\footnotetext{
${ }^{170}$ MOREIRA NETO, Diogo de Figueiredo. Curso de Direito Administrativo. 14. ${ }^{\text {a }}$ ed. Rio de Janeiro: Forense, 2005, p. 103.

${ }^{171}$ SCARTEZZINI, Ana Maria Goffi Flaquer. O princípio da continuidade do serviço público. São Paulo: Saraiva, 2006, p. 93.

${ }^{172}$ Refere-se, a propósito, previsão constante da Lei Orgânica do Município de São Paulo, em cujo parágrafo único do art. 123 estabelece-se que os serviços públicos serão prestados 'sem distinção de qualquer espécie'. (MEDAUAR, Odete. Direito Administrativo Moderno. 11. a ed. rev. atual. e ampl. São Paulo: Revista dos Tribunais, 2007, p. 316).
} 


\subsection{Origem e fundamentos normativos do princípio da continuidade}

Submetida ao princípio da continuidade, a Administração Pública - ou quem lhe faça às vezes - está expressamente impedida de, por qualquer motivo que não represente um interesse coletivo maior (e, a nosso ver, somente em casos excepcionais, com as ressalvas feitas ao longo deste trabalho) ${ }^{173}$, interromper a prestação dos serviços que disponibiliza.

De fato, a justificativa para a exigência da continuidade parece residir na própria natureza dos serviços públicos prestados, que têm em si implicada a ideia de atendimento às necessidades básicas da população e são, por isso, associados ao interesse público. ${ }^{174}$

Atribui-se a Louis Rolland o mérito da primeira sistematização dos princípios específicos do serviço público, no âmbito da qual elencou, como novidade, o princípio da continuidade do funcionamento dos serviços ao lado dos princípios da modificação e da igualdade de tratamento a ser conferida a todos os cidadãos/usuários. ${ }^{175}$

No espectro do direito estrangeiro, a continuidade também é apontada pela doutrina como exigência para uma prestação adequada dos

\footnotetext{
$173 \mathrm{O}$ art. $6^{\circ}{ }^{\circ}, \S 3 .^{\circ}$, II, da Lei de Concessões, estabelece que não se caracteriza como descontinuidade do serviço a sua interrupção, desde que ocorra mediante prévio aviso 'por inadimplemento do usuário, considerado o interesse da coletividade'. Retomaremos o exame desta lei, em cotejo com o princípio da continuidade e outros postulados constitucionais, no Capítulo 4, infra.

${ }^{174}$ Interesse público não é interesse da administração pública, anota Agustín Gordillo. Para o autor somente se pode falar em interesse público quando "em uma maioria de indivíduos, cada um pode encontra seu interesse individual: o 'interesse público' em que cada indivíduo não possa encontrar e identificar sua porção concreta de interesse individual é uma falácia." (Tratado de Derecho Administrativo [La defensa del usuario y del administrado]. 5. ed. Belo Horizonte: Del Rey e Fundación de Derecho Administrativo, 2003. Tomo p. VI-30). Na mesma obra, Gordillo aduz inexistir serviço público que não tenha por finalidade a satisfação de uma necessidade coletiva (expressão que utiliza como sinônima de interesse público). (Ibidem, p. VI-36).

${ }^{175}$ GROTT, Dinorá Adelaide Mussetti. O Serviço Público e a Constituição Brasileira de 1988. São Paulo: Malheiros Editores, 2003, p. 255.
} 
serviços públicos por parte da Administração Pública (ou por quem lhe faça às vezes), com algumas variações, porém, em seu sentido e extensão.

Diogo Freitas do Amaral sustenta que a "continuidade dos serviços públicos deve ser mantida", sendo essa uma das principais responsabilidades de qualquer Governo. Sintetiza a sua opinião, afirmando que em qualquer circunstância - até mesmo em caso de guerra ou de uma greve do funcionalismo público - "pode e deve ser assegurado o funcionamento regular dos serviços públicos, pelo menos dos essenciais." 176

À luz do direito espanhol, Santamaría Pastor afirma que a continuidade do funcionamento dos serviços públicos é um das principais razões que justificam a assunção, pelo Estado, de determinada atividade de serviço público. Para o autor, com a exigência da continuidade, procura-se garantir, dentre outros valores, que o serviço público (que cobra importantes necessidades coletivas) se encontre disponível para o cidadão de modo regular e contínuo. ${ }^{177}$

Em França - a exemplo do que se passa entre nós - a continuidade do serviço público é assumidamente um valor constitucional, como observa Eros Grau. ${ }^{178}$

José Roberto Dromi assevera que a continuidade do serviço (público) indica que este deve ser prestado toda a vez em que a necessidade que cobre se faça presente, "es decir que se efectúe oportunamente." ${ }^{179}$ Referido autor distingue, porém, os serviços

que por la necesidad colectiva que satisfacen, no pueden ser interrumpidos, por ejemplo la provisión de água potable, eletricidad,

\footnotetext{
${ }^{176}$ AMARAL, Diogo Freitas do. Curso de Direito Administrativo. 3. ${ }^{\text {a }}$ ed. Almedina: Coimbra, 2007, vol. I, p. 800.

${ }^{177}$ PASTOR, Santamaría. Principios de Derecho Administrativo. Volume II. Madri: Editorial Centro de Estudios Ramón Areces, 1999, p. 329.

${ }^{178}$ GRAU, Eros Roberto. Suspensão do fornecimento de energia elétrica: constitucionalidade, Código do Consumidor, princípios e postulados normativos aplicativos da razoabilidade e da proporcionalidade. Revista Trimestral de Direito Público, São Paulo, v. 36, 2001, p. 143.

${ }^{179}$ DROMI, José Roberto. Derecho administrativo. Tomo 2. Buenos Aires: Ástrea, 1992, p. 7.
} 
etc.; em estos casos estamos em presencia de continuidad absoluta. Tambiém puede hablarse de continuidad relativa cuando el servicio no se presta ininterrumpidamente, sino em determinados momentos, como por ejemplo, el servicio de bomberos, el de instrucción primaria, etcétera. No obstante los dos tipos de continuidad, el principio hay que mantenerlo inalterado, pues dada la necesidad colectiva del servicio, este debe prestarse. ${ }^{180}$

José Roberto Dromi ressalva, no entanto, a necessidade de não se confundirem os conceitos de regularidade do serviço com a exigência de sua continuidade. Regularidade, segundo o autor, significa que "el servicio debe prestarse conforme a reglas preestabelecidas o a determinadas normas; la continuidade significa que el servicio debe prestarse de manera ininterrumpida." ${ }^{181}$ Assim, para Dromi, enquanto a regularidade fala de ritmo e equilíbrio com que se presta o serviço, a continuidade faz referência a sua não paralisação ou interrupção. ${ }^{182}$

Carmela Leone, à luz do direito italiano - mas em constatação inteiramente válida para o nosso regime jurídico -, assume que o princípio da continuidade está incluído em um padrão fundamental da ação administrativa, ou seja, do 'bom andamento' da Administração, tal como assegurado pelos dizeres do art. 97, da Constituição Italiana. ${ }^{183}$ Para a autora, a despeito de expressa indicação legislativa, "pode se achar que o princípio da continuidade pode encontrar espaço junto dos outros princípios (ou padrões) que regulam a ação administrativa enquanto manifestação de um princípio mais generalizado". ${ }^{184}$

\footnotetext{
${ }^{180}$ DROMI, José Roberto. Derecho administrativo. Tomo 2. Buenos Aires: Ástrea, 1992, p. 7.

${ }^{181}$ Ibidem, p. 9 (os grifos são do original).

${ }^{182}$ Ibidem, p. 9.

183 LEONE, Carmela. Il principio di continuità dell'azione amministrativa. Milão: Giuffrè, 2007, especialmente p. 129.

${ }^{184}$ Ibidem, p. 129.
} 
A autora identifica a raiz do princípio em precedente da jurisprudência do Conselho de Estado que, em 1865 viu-se na contingência de decidir a respeito de problema da duração dos órgãos e de suas responsabilidades, fazendo-o à luz da exigência da continuidade da ação administrativa. ${ }^{185}$

Ainda segundo Carmela Leone, conquanto não expressamente assumido no texto constitucional italiano, o princípio da continuidade está expressamente indicado no art. 3. ${ }^{\circ}$ do Tratado Constitutivo da União Europeia, e também pelo art. I-19 da Constituição Europeia. ${ }^{186}$

Carmela Leone, acentua, ademais:

Neste quadro o aspecto da continuidade, expressando a exigência de constante operatividade e possibilidade de funcionamento do órgão, assim como a necessidade de constante exercício do poder e de evitar instabilidade de atos e efeitos, pode ser considerado uma articulação do princípio de bom andamento e constituir um princípio, dotado de carga de preceito autônoma. Pode aliás representar o conteúdo mínimo, a "base rígida do princípio de bom andamento e, portando, um standard qualitativo da administração, que não pode não existir, se não cancelando totalmente o preceito constitucional, que desta forma é (pelo menos em parte) especificado e idôneo a constituir um parâmetro suficientemente preciso. ${ }^{187}$

A mesma autora, em prosseguimento, reconhece o princípio da continuidade como padrão apenas da ação administrativa, mas igualmente da atividade legislativa. Para ela

${ }^{185}$ LEONE, Carmela. Il principio di continuità dell'azione amministrativa. Milão: Giuffrè, 2007, pp. 23-24.

${ }^{186}$ Ibidem, p. 129.

${ }^{187}$ Ibidem, pp. 131-132 (tradução livre do autor). 
Sem dúvida, estando correta a premissa segundo a qual o art. 97 Const. compreende e impõe o princípio de continuidade, o legislador tem a obrigação de garantir a constante operatividade do princípio, introduzindo em forma de lei as garantias que permitem que a ação administrativa não seja interrompida perante aqueles obstáculos dos quais foi falado (começando pela incapacidade e/ou impossibilidade do órgão funcionar). ${ }^{188}$

Entre nós, a continuidade dos serviços é uniformemente apontada como postulado fundamental do regime administrativo tanto no âmbito da doutrina e da jurisprudência, com algumas variações, porém, em seus contornos e efeitos. ${ }^{189}$ É bem verdade que se traduz em princípio implícito, mas com inegável assento constitucional, pois não é outra coisa senão projeção ou desmembramento de outros princípios guias do regime jurídico-administrativo, em particular o da eficiência.

Em posição já referida neste trabalho, Celso Antônio Bandeira Mello dá ao princípio da continuidade duplo sentido: de um lado, o de impossibilidade de sua interrupção por parte da Administração; de outro, o pleno direito dos administrados a que esse serviço não seja suspenso ou interrompido. ${ }^{190} \mathrm{E}$, de fato, o que se extrai do exame da legislação ordinária que regulamenta a matéria (Lei de Concessões), é que: (i) atendidas as condições de prestação do serviço, os usuários têm direito ao serviço adequado, tal qual está referido art. $6 .^{\circ}, \S 1 .^{\circ}$, de aludida lei; (ii) “o concessionário não lhes poderá negar

${ }^{188}$ LEONE, Carmela. Il principio di continuità dell'azione amministrativa. Milão: Giuffrè, 2007, especialmente p. 135 (tradução livre do autor). No mesmo norte, arremata a autora, em outra passagem de sua obra: "Com conclusão podemos afirmar que o princípio de continuidade deve representar uma constante referência não apenas para o legislador, ao qual cabe providenciar os instrumentos idôneos a garantir que a ação administrativa possa acontecer constantemente e com efeitos estáveis, mas também para a administração que (...) não poderá de qualquer forma não atender a estas exigências. E até o juiz, incluindo o constitucional que superando uma tradicional atitude restritiva - deverá julgar a lei considerando as consequências que a mesma produz sobre o perfil da violação do princípio da continuidade." (LEONE, Carmela. Il principio di continuità dell'azione amministrativa. Milão: Giuffrè, 2007, p. 141)

${ }^{189}$ O que será tema do nosso Capítulo IV, infra.

${ }^{190}$ MELlO, Celso Antônio Bandeira. Curso de Direito Administrativo. 27. ${ }^{\text {a }}$ ed. São Paulo: Malheiros Editores, 2010, p. 678. 
ou interromper a prestação, salvo, é claro, nas hipóteses previstas nas próprias cláusulas regulamentares."

No plano normativo, o princípio da continuidade pode ser visualizado em mais de um diploma.

Na Constituição Federal, estabelece o art. 175 incumbir ao "Poder Público, na forma da lei, diretamente ou sob regime de concessão ou permissão, sempre através de licitação, a prestação de serviços públicos”, constando do parágrafo único do mesmo preceito que "A lei disporá sobre: (...) IV - a obrigação de manter serviço adequado; (...)."

Neste rumo, a Lei de Concessões e Permissões dispôs, sob a epígrafe "Do Serviço Adequado" (Capítulo II), no art. 6. ${ }^{\circ}$, caput e parágrafo primeiro, o seguinte: “Toda concessão ou permissão pressupõe a prestação de serviço adequado ao pleno atendimento dos usuários, conforme estabelecido

${ }^{191}$ MELLO, Celso Antônio Bandeira. Curso de Direito Administrativo. 27. a ed. São Paulo: Malheiros Editores, 2010, p. 745. Segundo o autor "Cumpridas pelo usuário as exigências estatuídas, o concessionário está constituído na obrigação de oferecer o serviço de modo contínuo e regular. Com efeito, sua prestação é instituída não apenas em benefício da coletividade concebida em abstrato, mas dos usuários, individualmente considerados, isto é, daqueles que arcarão com o pagamento das tarifas a fim de serem servidos. Por isto, aquele a quem for negado o serviço adequado (art. $7 .^{\circ}, \mathrm{I}, \mathrm{c} / \mathrm{c} 6 .^{\circ}, \S 1 .^{\circ}$ ) ou que sofrer-lhe a interrupção pode, judicialmente, exigir em seu favor o cumprimento da obrigação do concessionário inadimplente, exercitando um direito subjetivo próprio." (Ibidem, mesma página).

${ }^{192}$ Referido autor, porém, tem opinião um pouco diversa daquela que adotamos neste trabalho (e a respeito da qual dedicaremos substancial parcela dos itens que seguem). São os seus dizeres: "É verdade que o art. $6 .^{\circ}, \S 3 .^{\circ}$, II, da lei de concessões, estabelece que não se caracteriza como descontinuidade do serviço a sua interrupção, mediante prévio aviso "por inadimplemento do usuário, considerado o interesse da coletividade'. A cautela existente na parte final deste versículo, leva a entender que algumas interrupções do serviço por inadimplência do usuário seriam inadmissíveis. Pense-se no caso de hospitais ou de estabelecimentos carcerários, ainda que o serviço de água ou de luz, por exemplo, estiverem sendo prestados por concessionário. De toda sorte, o problema das interrupções de serviço, segundo entendemos, não pode ser devidamente equacionado tão só ao lume da legislação ordinária. É que o serviço público, como evidente dever do Estado, é contemplado na própria Constituição. Está-se, pois, em face de matéria constitucional e que envolve direitos básicos da cidadania e da própria dignidade da pessoa humana. Bem o disse Weida Zancaner: 'os direitos dos usuários dos serviços públicos advêm dos princípios informadores do serviço público que têm por fundamento a própria Constituição. Nenhuma lei pode reduzir-lhes ou amesquinharlhes os contornos, nem a Administração Pública pode abdicar do fiel cumprimento destes direitos, direitos subjetivos públicos que cada um de nós, como usuários, tem o direito de exercitar contra o Estado-Poder'." (MELLO, Celso Antônio Bandeira. Curso de Direito Administrativo. 27. ed. São Paulo: Malheiros Editores, 2010, pp. 745-746). 
nesta Lei, nas normas pertinentes e no respectivo contrato. $\S 1$. $^{\text {S Serviço }}$ adequado é o que satisfaz as condições de regularidade, continuidade, eficiência, segurança, atualidade, generalidade, cortesia na sua prestação e modicidade das tarifas."

A mesma lei - adiante minudentemente examinada - dispôs [que]: “§ 3. N Não se caracteriza como descontinuidade do serviço a sua interrupção em situação de emergência ou após prévio aviso, quando: I - motivada por razões de ordem técnica ou de segurança das instalações; e, II - por inadimplemento do usuário, considerado o interesse da coletividade."193

A seu turno, o Código de Proteção e Defesa do Consumidor (Lei 8.078/90), em seu artigo 22, assegura ao consumidor a continuidade dos serviços essenciais, sob pena de responsabilização das pessoas jurídicas responsáveis pelo fornecimento do serviço. Estabelece, assim, referido preceito, in verbis:

"Os órgãos públicos, por si ou suas empresas, concessionárias, permissionárias ou sob qualquer outra forma de empreendimento, são obrigados a fornecer serviços adequados, eficientes, seguros e, quanto aos essenciais, contínuos. Parágrafo único. Nos casos de descumprimento, total ou parcial, das obrigações referidas neste artigo, serão as pessoas jurídicas compelidas a cumpri-las e a reparar os danos causados, na forma prevista neste código."

O Código do Consumidor não enumera quais seriam os serviços "essenciais". Inteiramente válida, neste sentido, a menção ao rol que a Lei $7.783 / 89^{194}$ (objeto de reflexão adiante) estabelece relativamente ao que é havido

\footnotetext{
${ }^{193}$ No capítulo III dessa mesma lei, encontram-se enumerados os "direitos e obrigações dos usuários", momento em que novamente se faz expressa menção à adequação do serviço como um direito do usuário (vide art. 7, inciso I, da Lei em comento).

${ }^{194}$ Dispõe sobre o exercício do direito de greve, define as atividades essenciais, regula o atendimento das necessidades inadiáveis da comunidade, e dá outras providências.
} 
como serviço essencial. Estabelece o art. 10 de aludida lei que são considerados serviços ou atividades essenciais:

"I - Tratamento e abastecimento de água; produção e distribuição de energia elétrica, gás e combustíveis;

II - Assistência médica e hospitalar;

III - Distribuição e comercialização de medicamentos e alimentos;

IV - Funerários;

$\mathrm{V}$ - Transporte coletivo;

VI - Captação e tratamento de esgoto e lixo;

VII - Telecomunicações;

VIII - Guarda, uso e controle de substâncias radioativas, equipamentos e materiais nucleares;

IX - Processamentos de dados ligados a serviços essenciais;

$\mathrm{X}$ - Controle de tráfego aéreo;

XI - Compensação 'bancária'.”

Retomaremos o exame da Lei n. ${ }^{\circ} 7.783 / 89$ mais adiante, por ocasião do estudo em torno da legitimidade e possibilidade da greve e seu impacto no princípio da continuidade das funções públicas. Por ora, competenos refletir sobre o espectro de incidência do princípio da continuidade, procurando responder à indagação consistente em saber se esse postulado tem sua abrangência limitada aos serviços essenciais ou, de maneira mais abrangente, estende-se a quaisquer serviços públicos.

Consoante se anotou linhas atrás, todos os serviços públicos seriam, em tese, essenciais. Porém, como também se sublinhou, a distinção proposta entre serviços essenciais e não essenciais é inteiramente válida e útil na exata medida em que há, de fato, serviços cuja prestação pode ser adiada ou interrompida e outros cujo atendimento não comporta interrupção de maneira alguma (ou porque assim o diz a lei, ou porque essa impossibilidade deflui da 
própria natureza do serviço). ${ }^{195}$ São os serviços que, segundo se anotou, "não podem parar', e que consubstanciam terreno fértil para a incidência do princípio da continuidade. ${ }^{196}$

Identificados os contornos gerais do princípio da continuidade, compete-nos dar um passo à frente, passando ao exame das consequências derivadas da exigência da continuidade do serviço público, exigência essa que projeta singulares efeitos nos campos dos contratos administrativos, do direito de greve e da substituição de servidores.

A respeito destes pontos - para nós, os três mais relevantes e sensíveis terrenos de incidência e atuação do princípio em voga - dedicaremos o Capítulo 4, infra.

\footnotetext{
${ }^{195}$ Antecipando preocupação sobre a qual nos debruçaremos mais adiante, aduz Rizzato Nunes: "Há no serviço considerado essencial um aspecto real e concreto de urgência, isto é, necessidade concreta e efetiva de sua prestação. O serviço de fornecimento de água para uma residência não habitada não se reveste dessa urgência. Contudo, o fornecimento de água para uma família é essencial e absolutamente urgente, uma vez que as pessoas precisam de água para sobreviver. Essa é a preocupação da norma" (NUNES, Rizzatto. Comentários ao Código de Defesa do Consumidor. 2. ed. reform. São Paulo: Saraiva, 2005, p. 309).

196 Ana Maria Goffi Flaquer Scartezzini tem opinião diferente. Para ela "a distinção [entre serviços essenciais e não essenciais], entretanto, é de pouca valia, dada a fluidez do conceito de essencialidade, variável em situação e momento histórico diversos. Com efeito, a necessidade social pode impelir para determinada opção, em dado momento e lugar, que, no entanto, pode não perdurar e, em consequência, alterar a própria distinção dos serviços públicos." (SCARTEZZINI, Ana Maria Goffi Flaquer. O princípio da continuidade do serviço público. São Paulo: Malheiros Editores, 2006, pp. 94-95).
} 


\section{REPERCUSSÕES DO PRINCÍPIO DA CONTINUIDADE}

\subsection{Notas introdutórias}

Neste capítulo, nosso foco de atenção dirige-se ao estudo das consequências que se projetam no campo dos contratos administrativos (em particular, os de concessão e permissão de serviços públicos), no direito de greve, e, por derradeiro, nas figuras de substituição dos servidores públicos.

Questões importantes em torno da problemática lançada serão enfrentadas neste tópico, em particular as que giram em torno de saber se o princípio da continuidade é, afinal, absoluto ou se, diversamente, cede espaço diante de determinadas e específicas situações (e em que medida isso ocorre).

É o que passamos a examinar.

\subsection{A suspensão do fornecimento de serviço público essencial por} inadimplemento do usuário e o princípio da continuidade

Compete-nos, nas linhas seguintes, examinar o princípio da continuidade em cotejo com a inadimplência do usuário do serviço público, enfrentando a possibilidade dos prestadores de serviços públicos essenciais (em particular, o fornecimento de energia elétrica e de água) suspenderem, unilateralmente, a prestação dos serviços ante a inadimplência do usuário. $\mathrm{O}$ estudo do tema passará, necessariamente, pelo princípio da dignidade da pessoa humana, da razoabilidade e da proporcionalidade. 
Como ponto de partida, vale o registro de que a gradativa - e cada vez mais crescente - transferência da prestação dos serviços públicos para a iniciativa privada, mediante as figuras das concessões e das permissões ${ }^{197}$ imprimiu nova conformação e exigiu, como é natural, a atenção para novas questões. Direitos dos usuários são colocados à evidência e, diuturnamente, confrontados com os direitos dos prestadores de serviços. O equacionamento dos interesses econômicos postos em jogo com a devida proteção do usuário parece ser, a todos os títulos, a melhor solução.

O enfrentamento da problemática em torno da suspensão do fornecimento do serviço público em face de inadimplemento do usuário pressupõe antes de tudo, porém, uma breve rememoração em torno de conceitos já fixados neste trabalho e daquilo que a doutrina e a jurisprudência têm, ao longo dos últimos anos, debatido e construído.

Em primeiro lugar importa ter presente importante distinção feita entre os serviços públicos próprios, de um lado, e impróprios, de outro: enquanto os primeiros são prestados pelo Estado de maneira gratuita, os últimos sujeitamse à contraprestação, abrindo espaço, por isso, para eventual possibilidade de suspensão do serviço ante o inadimplemento do usuário. Essa segunda categoria - a dos serviços impróprios e, em particular, os serviços uti singuli ${ }^{198}$ - é a que nos interesse, para a finalidade deste item.

Ademais, vale sublinhar que a exigência de continuidade consta, no plano normativo, em vários diplomas.

$\mathrm{O}$ art. 175, parágrafo único, inciso IV da Constituição Federal, ao lado da Lei 8.987/95, dispõem sobre o regime de concessão e permissão de

\footnotetext{
${ }^{197}$ E, mais recentemente, de outras figuras como, e.g., a regulação e as parcerias públicoprivadas, (vide Capítulo 1, supra).

${ }^{198}$ Conquanto inexista uniformidade quanto ao conceito de serviço público (assim como divergência quanto à característica da essencialidade deste), não se coloca em dúvida que os serviços de fornecimento de água e de energia elétrica - nos quais centraremos nosso exame e atenção neste item - enquadram-se como serviços públicos e, dentro das múltiplas classificações já examinadas, serviços uti singuli.
} 
serviços públicos, estabelecendo esta ultima em seu art. 6. ${ }^{\circ}$, que "Toda concessão ou permissão pressupõe a prestação de serviço adequado ao pleno atendimento dos usuários", afirmando, a seu turno, no $\S 1 .^{\circ}$ o conceito de serviço adequado como "o que satisfaz as condições de regularidade, continuidade, eficiência, segurança, atualidade, generalidade, cortesia na sua prestação e modicidade das tarifas”.

A referência à continuidade da prestação, porém, antes disso, já podia ser encontrada no Código de Proteção e Defesa do Consumidor, em cujo art. 22 se lê: "Os órgãos públicos, por si ou suas empresas, concessionárias, permissionárias ou sob qualquer outra forma de empreendimento, são obrigados a fornecer serviços adequados, eficientes, seguros e, quanto aos essenciais, contínuos."199

Nota-se, no entanto, que a imposição de continuidade da prestação não consubstancia princípio absoluto. Em determinadas hipóteses - como, por exemplo, de ligações clandestinas - antes mesmo do advento da Lei de Concessões e Permissões e da expressa previsão aí contemplada (art. 6. ${ }^{\circ}, \S 3 .^{\circ}$, adiante examinado), doutrina e jurisprudência haviam por legítima a interrupção do fornecimento do serviço, desde que, como é natural, presentes os respectivos requisitos. ${ }^{200}$

A Lei de Concessões e Permissões (Lei n. ${ }^{\circ}$ 8.987), como se adiantou, trouxe expressa previsão das duas hipóteses em que se autorizaria a suspensão do serviço. Com efeito, estabelece o art. 6. ${ }^{\circ}, \S 3 .^{\circ}$, da lei referida, in verbis: "Não se caracteriza como descontinuidade do serviço a sua interrupção em situação de emergência ou após prévio aviso, quando: I - motivada por

\footnotetext{
199 Ademais, dispõe o art. 42, do mesmo diploma (CDC): "Na cobrança de débitos, o consumidor inadimplente não será exposto a ridículo, nem será submetido a qualquer tipo de constrangimento ou ameaça."

200 PINHEIRO, Cláudia Travi Pitta. A suspensão de serviço público em virtude do inadimplemento do usuário à luz dos princípios da boa-fé e da proporcionalidade. Revista de Direito do Consumidor, São Paulo, v. 40, out./dez. 2001, p. 65.
} 
razões de ordem técnica ou de segurança das instalações; II - por inadimplemento do usuário, considerado o interesse da coletividade. „201

Isso significa que, sob a ótica do estabelecido no plano normativo (Lei 8.987), a interrupção estaria condicionada à ocorrência de uma das duas hipóteses: $(i)$ desde que exigida por razões de ordem técnica ou de segurança das instalações; (ii) ante o inadimplemento do usuário, mas ainda nessa última hipótese, o direito de interrupção está subordinado ao interesse da coletividade, de tal modo que "se a ausência do serviço causa prejuízo a interesses transindividuais, fica suprimida a faculdade do prestador."202

A primeira hipótese autorizadora da suspensão do fornecimento de serviço público diz respeito às situações de razões de ordem técnica ou segurança das instalações ${ }^{203}$, hipótese que se justifica em face do objetivo maior, que é o da melhoria da qualidade e da própria garantia da continuidade da prestação do serviço, despertando pouca polêmica em sua aplicação.

A controvérsia centra-se, essencialmente, em torno do inciso II.

Considere-se por relevante, a Lei 9.427/96, que instituiu a Agência Nacional de Energia Elétrica - ANEEL e disciplinou o regime das concessões de serviços públicos de energia elétrica, e em cujo âmbito se prevê: “Art. 17. A suspensão, por falta de pagamento, do fornecimento de energia elétrica a consumidor que preste serviço público ou essencial à população e cuja atividade sofra prejuízo será comunicada com antecedência de quinze dias ao Poder Público local ou ao Poder Executivo Estadual. $§ 1 .^{\circ}$ O Poder Público que receber a comunicação adotará as providências administrativas para preservar a população dos efeitos da suspensão do fornecimento de energia elétrica, inclusive dando publicidade à contingência, sem prejuízo das ações de

\footnotetext{
${ }^{201}$ Os grifos não constam do original.

202 PINHEIRO, Cláudia Travi Pitta. A suspensão de serviço público em virtude do inadimplemento do usuário à luz dos princípios da boa-fé e da proporcionalidade. Revista de Direito do Consumidor, São Paulo, v. 40, out./dez. 2001, p. 68.

${ }^{203}$ Ficariam compreendidos, neste dispositivo, também as situações imprevisíveis decorrentes de força maior ou caso fortuito, tais como inundações e tempestades.
} 
responsabilização pela falta de pagamento que motivou a medida." (Redação dada pela Lei 10.438/2002) $204-205$

Poder-se-ia imaginar, em face desse cenário, que a expressa enumeração das hipóteses autorizadoras da interrupção do serviço pela Lei 8.987 teria colocado uma pá de cal na controvérsia que há muito envolvia o assunto. Isso, porém, passa muito longe da verdade.

Não tardou nada para que a validade da Lei 8.987 fosse posta em dúvida, sobretudo em termos constitucionais, quanto à adequação e conformidade desta previsão aos postulados assegurados em nível constitucional (e a respeito do quais dedicamos algumas linhas no Capítulo 2, supra).

Celso Antônio Bandeira de Mello pondera:

\footnotetext{
204 Ainda, consta do $§ 2 .^{\circ}$ deste mesmo artigo, com a redação da Lei 10.762/2003: "Sem prejuízo do disposto nos contratos em vigor, o atraso do pagamento de faturas de compra de energia elétrica e das contas mensais de seu fornecimento aos consumidores, do uso da rede básica e das instalações de conexão, bem como do recolhimento mensal dos encargos relativos às quotas da Reserva Global de Reversão - RGR, à compensação financeira pela utilização de recursos hídricos, ao uso de bem público, ao rateio da Conta de Consumo de Combustíveis $\mathrm{CCC}$, à Conta de Desenvolvimento Energético - $\mathrm{CDE}$, ao Programa de Incentivo às Fontes Alternativas de Energia Elétrica - PROINFA e à Taxa de Fiscalização dos Serviços de Energia Elétrica, implicará a incidência de juros de mora de um por cento ao mês e multa de até cinco por cento, a ser fixada pela ANEEL, respeitado o limite máximo admitido pela legislação em vigor. A Resolução da ANEEL n. ${ }^{\circ}$ 456/2000, a seu turno, art. 73 e seu parágrafo único, dispõe:

“Art. 73. Nos casos de revisão do faturamento, motivada por uma das hipóteses previstas no artigo anterior, a concessionária poderá cobrar o custo administrativo adicional correspondente a, no máximo, 30\% (trinta por cento) do valor líquido da fatura relativa à diferença entre os valores apurados e os efetivamente faturados. Parágrafo único. Sem prejuízo da suspensão do fornecimento prevista no art. 90, o procedimento referido neste artigo não poderá ser aplicado sobre os faturamentos posteriores à data da constatação da irregularidade, excetuado na hipótese de auto-religação descrita no inciso II, art. 74."

${ }^{205}$ No ano de 2007 entrou em vigor a Lei de Diretrizes Nacionais para o Saneamento Básico (Lei 11.445/07), reforçando a previsão da Lei de Concessões quanto à continuidade do serviço, prevendo também a possibilidade de suspensão do serviço de fornecimento de água quando o consumidor, conquanto previamente avisado, não efetua o pagamento da remuneração. Essa mesma lei contém dispositivo (art. 40, inc. $\mathrm{V}, \S 33^{\circ}$ ) estabelecendo que, em se tratando de estabelecimentos de saúde, instituições educacionais e de internação coletiva de pessoas e de usuário de baixa renda beneficiário de tarifa social, a interrupção do fornecimento do serviço público essencial deverá observar prazos e critérios para que sejam preservadas as condições mínimas que mantenham a saúde dos cidadãos.
} 
É verdade que o art. $6 .^{\circ}, \S 3 .^{\circ}$, II, da lei de concessões, estabelece que não se caracteriza como descontinuidade do serviço a sua interrupção, mediante prévio aviso 'por inadimplemento do usuário, considerado o interesse da coletividade'. (...) De toda sorte, o problema das interrupções de serviço, segundo entendemos, não pode ser devidamente equacionado tão só ao lume da legislação ordinária. É que o serviço público, como evidente dever do Estado, é contemplado na própria Constituição. Está-se, pois, em face de matéria constitucional e que envolve direitos básicos da cidadania e da própria dignidade da pessoa humana. Bem o disse Weida Zancaner: 'os direitos dos usuários dos serviços públicos advêm dos princípios informadores do serviço público que têm por fundamento a própria Constituição. Nenhuma lei pode reduzir-lhes ou amesquinhar-lhes os contornos, nem a Administração Pública pode abdicar do fiel cumprimento destes direitos, direitos subjetivos públicos que cada um de nós, como usuários, tem o direito de exercitar contra o Estado-Poder'. ${ }^{206}$

Ainda no campo da doutrina, Cláudia Lima Marques consignou, há muito, a sua opinião a respeito, consignando: "Nas relações entre consumidor e prestador de serviço tipicamente públicos de primeira necessidade dois pontos de discórdia podem ser identificados: a tendência, hoje amenizada pela ação da jurisprudência, de impor mudanças unilaterais, prejudicando a posição já vulnerável do consumidor e em segundo lugar, a forma de cobrança de créditos, com cortes imediatos ou sistemáticos do fornecimento destes serviços."

\footnotetext{
${ }^{206}$ MELLO, Celso Antônio Bandeira. Curso de Direito Administrativo. 27. ${ }^{a}$ ed. São Paulo: Malheiros Editores, 2010, pp. 745-746.

${ }^{207}$ MARQUES, Cláudia Lima. Comentários ao Código de Proteção e Defesa do Consumidor. OLIVEIRA, Juarez (Coord.). São Paulo: Saraiva, 1991, p. 111.

${ }^{208}$ A respeito opina Mário Aguiar Moura: "A continuidade dos serviços essenciais significa que devem ser eles prestados de modo permanente sem interrupção, salvo ocorrência de caso fortuito ou força maior que determine sua paralisação passageira. A hipótese é a de o particular já estar recebendo o serviço. Não pode a pessoa jurídica criar descontinuidade. Serviços essenciais são todos os que se tornam indispensáveis para a conservação, preservação da vida, saúde, higiene, educação e trabalho das pessoas. Na época moderna, exemplificativamente, se tornaram essenciais, nas condições de já estarem sendo prestados, o transporte, água, esgoto, fornecimento de eletricidade com estabilidade, linha telefônica, limpeza urbana, etc." (MOURA, Mário Aguiar. O Poder Público como fornecedor perante o Código de Defesa do Consumidor. Repertório de jurisprudência IOB, São Paulo, 2. ${ }^{a}$ quinzena de abril/92, p. 17).
} 
A jurisprudência, de início, inclusive a do Superior Tribunal de Justiça, negou validade e aplicabilidade à referida lei, entendendo pela impossibilidade, em qualquer hipótese, da interrupção do serviço em razão do inadimplemento. Fundamentalmente, tal entendimento assenta-se em três premissas ou argumentos: $(i)$ a interrupção do serviço malfere o disposto no art. 42, do Código de Proteção e Defesa do Consumidor; (ii) tal interrupção caracteriza exercício arbitrário das próprias razões; (iii) implica em verdadeira justiça privada ou autotutela, providência essa que não encontra amparo constitucional nem legal. ${ }^{209}$

O Superior Tribunal de Justiça, adotando essa linha de pensamento, decidindo em reiteradas ocasiões ser “(...) defeso à concessionária de energia elétrica interromper o suprimento de força, no escopo de compelir o consumidor ao pagamento de tarifa em atraso", consignando-se que "o exercício arbitrário das próprias razões não pode substituir a ação de cobrança. ${ }^{210}$ No mesmo sentido, o STJ reconheceu ser "condenável o ato praticado pelo usuário que desvia energia elétrica, sujeitando-se até a responder penalmente", ressalvando, porém, que tal violação não resultaria em reconhecer como legítimo ato administrativo praticado pela empresa concessionária fornecedora de energia e consistente na interrupção do fornecimento da mesma. Consta de emblemático trecho da ementa do acórdão:

“3. A energia é, na atualidade, um bem essencial à população, constituindo-se serviço público indispensável subordinado ao princípio da continuidade de sua prestação, pelo que se torna impossível a sua

\footnotetext{
Dedicando-se ao estudo do art. 22, do CDC, Antônio Herman de Vasconcellos e Benjamin, destacou: "A segunda inovação importante é a determinação de que os serviços essenciais - e só eles - devem ser contínuos, isto é, não podem ser interrompidos. Cria-se para o consumidor um direito à continuidade do serviço. Tratando-se de serviço essencial e não estando ele sendo prestado, o consumidor pode postular em juízo que se condene a Administração a fornecê-lo." (Antônio Herman de Vasconcellos e Benjamin et. al. Comentários ao Código de Proteção ao Consumidor, São Paulo: Saraiva, 1991. p. 111).

209 PINHEIRO, Cláudia Travi Pitta. A suspensão de serviço público em virtude do inadimplemento do usuário à luz dos princípios da boa-fé e da proporcionalidade. Revista de Direito do Consumidor. v.40. São Paulo: RT, out./dez. 2001, p. 66.

${ }^{210}$ Ibidem, mesma página.
} 
interrupção. 4. Os arts. 22 e 42, do Código de Defesa do Consumidor, aplicam-se às empresas concessionárias de serviço público. 5. O corte de energia, como forma de compelir o usuário ao pagamento de tarifa ou multa, extrapola os limites da legalidade. 6. Não há de se prestigiar atuação da Justiça privada no Brasil, especialmente, quando exercida por credor econômica e financeiramente mais forte, em largas proporções, do que o devedor. Afronta, se assim fosse admitido, aos princípios constitucionais da inocência presumida e da ampla defesa. 7. O direito do cidadão de se utilizar dos serviços públicos essenciais para a sua vida em sociedade deve ser interpretado com vistas a beneficiar a quem deles se utiliza. 8. Recurso improvido.",211

Atualmente, porém, essa posição é representativa da jurisprudência minoritária dos Tribunais.

Recentemente, o Tribunal de Justiça do Estado de São Paulo, por intermédio da sua 23. ${ }^{\text {a }}$ Câmara de Direito Privado, acolheu orientação que, no âmbito do Superior Tribunal de Justiça, pode-se dizer superada. Como quer que seja, vale o registro de que, nessa decisão recente, foi reconhecida a impossibilidade de 'corte' do serviço público havido por essencial (in casu, tratava-se de energia elétrica), consoante a ementa vazada em trecho adiante transcrito: "Energia elétrica - Corte do fornecimento em razão de atraso no pagamento - Impossibilidade de se realizar o desligamento por se tratar de serviço público essencial à vida em sociedade - Recurso improvido.”212

Em passagem do voto do relator - algo longo, mas deveras esclarecedor, razão pela qual é adiante reproduzido - acerca da citada orientação adotada pela 23. ${ }^{a}$ Câmara do TJSP, consigna-se o seguinte:

${ }^{211}$ BRASIL. Superior Tribunal de Justiça. Primeira Turma. RMS 8915/MA. Rel. Min. José Delgado. Julgamento em 12/05/1998. Disponível em http://www.stj.jus.br. Acesso em $10 / 02 / 2011$.

212 BRASIL. Tribunal de Justiça do Estado de São Paulo. Agravo de Instrumento n. ${ }^{\text {o }}$ 990.10.328773-8. 23. a Câmara de Direito Privado. Rel. Des. J. B. Franco de Godói. Julgamento em 01/12/2010. Disponível em http://www.tj.sp.gov.br. Acesso em 10/02/2011. 
"Mesmo em casos de extrema gravidade, tal como o do desvio criminoso de energia elétrica, o Superior Tribunal de Justiça tem entendido que nem assim poderá a concessionária de serviço público realizar o desligamento por se tratar de serviço público essencial para a vida em sociedade:

'É condenável o ato praticado pelo usuário que desvia energia elétrica, sujeitando-o até a responder penalmente. Essa violação contudo, não resulta em reconhecer, como legítimo, ato administrativo praticado pela empresa concessionária fornecedora de energia elétrica e consistente na interrupção do fornecimento da mesma. A energia é, na atualidade, um bem essencial à população, princípio da continuidade de sua prestação, pelo que torna impossível a sua interrupção.'

E, acrescenta com clareza solar o acórdão:

'Os arts. 22 e 42 do Código de Defesa do Consumidor se aplicam às empresas concessionárias de serviço público. O corte de energia, como forma de compelir o usuário ao pagamento de tarifa ou multa, extrapola os limites da legalidade.'

E, ainda em uma lição sobre os princípios gerais do Direito afirma o v. aresto:

'Não há de se prestigiar atuação da Justiça privada no Brasil, especialmente, quando exercida por credor econômica e financeiramente mais forte, em largas proporções, do que o devedor. Afronta, se assim fosse admitido, aos princípios constitucionais da inocência presumida e da ampla defesa. $O$ direito do cidadão de se utilizar dos serviços públicos essenciais para a sua vida em sociedade deve ser interpretado com vistas a beneficiar a quem deles se utiliza' (Rec. Ord. em Mandado de Segurança n. ${ }^{\circ}$ 8.915/MA - rei. Min. JOSÉ DELGADO - 1. ${ }^{\text {a }}$ Turma - j . 12.05 .98 - v.u.).,213

Indo de um pólo a outro, o Tribunal de Justiça de São Paulo recentemente entendeu pela legalidade da suspensão de serviço essencial ante a

213 BRASIL. Tribunal de Justiça do Estado de São Paulo. Agravo de Instrumento n. ${ }^{\circ}$ 990.10.328773-8. 23. ${ }^{\text {a }}$ Câmara de Direito Privado. Rel. Des. J. B. Franco de Godói. Julgamento em 01/12/2010. Disponível em http://www.tj.sp.gov.br. Acesso em 10/02/2011 (os destaques são do original). 
inadimplência do usuário, o que fez lastreado na Lei de Concessões e Permissões, exigindo, para tanto, a existência de comprovada comunicação prévia ao usuário, com prazo para o pagamento. Eis o que consta da ementa de referido acórdão: "Mandado de segurança - Fornecimento de energia elétrica Interrupção por inadimplência do consumidor - Admissibilidade - Direito líquido e certo não comprovado na espécie - Denegação da ordem - Apelação provida."214

A orientação predominante da jurisprudência na atualidade é, porém, algo diversa. Com inteiro acerto, a nosso ver, os Tribunais - e, em particular, o Superior Tribunal de Justiça - adotam entendimento que se pode dizer "intermediário", reconhecendo a legitimidade da suspensão do serviço ante o inadimplemento do consumidor, considerados alguns requisitos: (1) que tenha havido aviso prévio; (2) que a suspensão decorra de débitos atuais, e não pretéritos (estes passíveis de cobrança pelas vias ordinárias, sem risco algum, portanto, a uma afronta aos dizeres do art. 42, do CDC).

Lastreia-se, essa posição, no forte argumento de que o serviço essencial só pode ser interrompido como medida de exceção e, em que pese a lei autorizar o 'corte' por inadimplência do usuário, tal medida só se mostra dentro da legalidade quando utilizada como medida coercitiva para pagamento de débito atual (do mesmo mês ou duas ou três contas em atraso). Considera-se, pois, abusiva se a pretendida medida disser respeito a débitos pretéritos, pois o prestador de serviço dispõe de outros meios legítimos (e ação própria) para a cobrança desses débitos.

Com efeito, o Superior Tribunal de Justiça tem firmado o seguinte entendimento: “... Quanto ao inadimplemento do usuário comum, a Primeira Seção e a Corte Especial do STJ entendem legal a suspensão do serviço de

214 BRASIL. Tribunal de Justiça do Estado de São Paulo. Apelação com revisão n. ${ }^{\circ}$ 992.09.045591-5. 33. . Câmara de Direito Privado. Rel. Des. Cristiano Ferreira Leite. Julgamento em 25/10/2010. Disponível em http://www.tj.sp.gov.br. Acesso em 10/02/2011. 
fornecimento de energia elétrica pelo inadimplemento do consumidor, após aviso prévio, não configurando descontinuidade de prestação de serviço público. (REsp 460.271/SP, Rel. Min. Eliana Calmon, DJU 21/02/2005; REsp 591.692/RJ, Rel. Min. Teori Albino Zavascki, DJU 14.3.2005; REsp 615.705/PR, Rel. Min. Luiz Fux, DJU 13/12/2004; AgRg nos EDcl no Ag 1155026/SP 2009/0056551-8 Rel. Min. HAMILTON CARVALHIDO DJe 22/04/2010; REsp 313606 / AL 2001/0034873-4 Rel. Min. HERMAN BENJAMIN DJe 17/12/2009; AgRg no REsp 854204/AL 2006/0126152-2 Rel. Min. BENEDITO GONÇALVES DJe 18/11/2010; AgRg no REsp 1119165/MA 2009/0111127-7 Rel. Min. CASTRO MEIRA, DJe 28/10/2010)."215

Nesse mesmo contexto, o STJ consigna a ressalva acerca da impossibilidade da interrupção nas situações de dívidas pretéritas, e não atuais. É o que se extrai do trecho da ementa do seguinte julgado: “O Superior Tribunal de Justiça consagra entendimento no sentido de que não é lícito à concessionária interromper os serviços de fornecimento de energia elétrica por dívida pretérita, a título de recuperação de consumo, em face da existência de outros meios legítimos de cobrança de débitos antigos não pagos. (REsp 662.204/RS, Rel. Min. TEORI ALBINO ZAVASCKI, Primeira Turma, DJ de 3/12/07; REsp 821.991/SP, Primeira Turma, Rel. Min. LUIZ FUX, DJ de 1\%6/06; REsp 1.076.485/RS, Rel. Min. ELIANA CALMON, Segunda Turma, DJe de 27/3/09; AgRg no REsp 793.539/RS, Rel. Min. HERMAN BENJAMIN, Segunda Turma, DJe de 19/6/09).,"216-217

\footnotetext{
${ }^{215}$ BRASIL. Superior Tribunal de Justiça. EREsp 845982/RJ. Primeira Seção. Relator Min. Luiz Fux. DJe 03/08/2009. Disponível em http://www.stj.jus.br. Acesso em 30/11/2010.

216 BRASIL. Superior Tribunal de Justiça. EREsp 845982/RJ (EMBARGOS DE DIVERGÊNCIA EM RECURSO ESPECIAL 2006/0269086-7), Relator Min. Luiz Fux, Primeira Seção, DJe 03/08/2009. Disponível em http://www.stj.jus.br. Acesso em 30/11/2010.

${ }^{217}$ O Tribunal de Justiça de São Paulo tem encampado maciçamente esta orientação: “(...). O PRINCÍPIO DA CONTINUIDADE DO SERVIÇO NÃO IMPEDE A SUSPENSÃO DO FORNECIMENTO PARA CONSUMIDOR INADIMPLENTE CONTUMAZ, VISTO QUE HÁ EXPRESSA PREVISÃO LEGAL PARA TANTO. RECURSO PROVIDO.” (BRASIL. Tribunal de Justiça do Estado de São Paulo. Ag. 990.10.265584-9. 22. ${ }^{a}$ Câmara de Direito Privado. Rel. Des. Campos Mello. Julgamento em 28/10/2010); "PRESTAÇÃO DE SERVIÇOS. ENERGIA ELÉTRICA. SUSPENSÃO DO FORNECIMENTO.
} 
Idêntica posição, contudo, não pode ser legitimamente sustentada quando o inadimplemento provém de unidades públicas, tais como hospitais, delegacias, pronto-socorros ou escolas, por exemplo - é dizer, situações de essencialidade extrema.

Parece adequado distinguir, neste passo, duas situações, cujas conclusões a respeito da legitimidade da interrupção variam conforme se trate de uma ou outra hipótese. Uma primeira situação é aquela em que está presente uma relação envolvendo o usuário "comum"; outra, diferentemente, é a que envolve as unidades públicas, aqui chamadas de usuários "especiais".

Relativamente à primeira categoria de usuários (os ditos 'comuns'), não remanesce dúvida quanto ao acerto e à manutenção da posição acima sustentada, quanto à legitimidade da interrupção, desde que precedida de aviso e compreensiva de débitos atuais e não pretéritos. A segunda situação cogitada, entretanto, exige outra solução, sendo certo que a suspensão do fornecimento em casos tais implicaria, a um só tempo, desconsiderar-se sumariamente o interesse da coletividade e o próprio princípio da continuidade da prestação de serviços públicos. ${ }^{218}$

IRREGULARIDADE. IMPOSSIBILIDADE. DÉBITO PRETÉRIO. PREVALÊNCIA DOS PRECEITOS CONSUMERISTAS. RECURSO IMPROVIDO. A jurisprudência é consistente na vedação de suspensão do fornecimento de energia elétrica por débito pretérito e determinado, especialmente se firmado negócio jurídico de confissão da dívida pelo usuário na época. No mais, em que pese o reconhecimento da existência da irregularidade pelo douto Magistrado, não se pode olvidar que a suspensão do fornecimento de energia se mostra abusiva, já que dispõe a concessionária dos meios legais para satisfazer sua pretensão, sem que com isso tenha que suprimir o fornecimento de serviço público de natureza essencial. Assim, necessária se faz a prevalência das leis que protegem a parte hipossuficiente." (BRASIL. Tribunal de Justiça do Estado de São Paulo. Apelação com revisão n. ${ }^{\circ}$ 990.10.030228-0. 31. ${ }^{a}$ Câmara de Direito Privado. Rel. Des. Adilson de Araujo. Julgamento em 16/11/2010. Disponível em http://www.tj.sp.gov.br. Acesso em 28/12/2010); "Agravo de instrumento - Declaratória de ilegalidade de corte de energia - Tutela antecipada - Indeferimento - Serviço essencial que somente situações excepcionais permitiriam a descontinuidade do serviço - Corte de energia por débitos pretéritos - Não há notícia de adulteração na forma de medição - Possibilidade de concessão da liminar - Recurso provido." (BRASIL. Tribunal de Justiça do Estado de São Paulo. Agravo de Instrumento n. ${ }^{\circ}$ 990.10.315972-1. 20. ${ }^{a}$ Câmara de Direito Privado. Rel. Des. Miguel Petroni Neto. Julgamento em 20/09/2010. Disponível em http://www.tj.sp.gov.br. Acesso em 28/12/2010).

${ }^{218}$ Compartilha desse ponto de vista Fernando da Costa de Azevedo, para quem o $\S 3 .^{\circ}$ do art. $6^{\circ}{ }^{\circ}$ da Lei $8.987 / 1995$ não viola o princípio da continuidade, desde que a suspensão por 
Endossamos, neste ponto, a orientação sufragada pelo Superior Tribunal de Justiça em mais de uma ocasião: “A suspensão do serviço de energia elétrica, por empresa concessionária, em razão de inadimplemento de unidades públicas essenciais - hospitais; pronto-socorros; escolas; creches; fontes de abastecimento d'água e iluminação pública; e serviços de segurança pública -, como forma de compelir o usuário ao pagamento de tarifa ou multa, despreza o interesse da coletividade." 219 Em outro julgado, alinhando-se a esse mesmo entendimento, reconheceu-se que as Turmas de Direito Público daquela Côrte vem entendendo que quando o devedor for ente público, o corte de energia não poderá ser realizado "indiscriminadamente em nome da preservação do próprio interesse coletivo, sob pena de atingir a prestação de serviços públicos essenciais, tais como hospitais, centros de saúde, creches, escolas e iluminação pública."220

José Carlos de Oliveira sustenta, neste caminhar, a impossibilidade de se considerar - para a solução da questão - apenas e tão somente o texto do art. 22, do CDC. Segundo ele, merece particular atenção também o inciso II do já referido art. $6^{\circ}{ }^{\circ}$, da Lei 8.987/95, concluindo-se pela impossibilidade da concessionária suspender o fornecimento, mesmo diante do

inadimplência "ocorra fora das situações que representem o interesse da coletividade: a miserabilidade ou desemprego do usuário-pessoa física; a prestação de serviços de relevância social para o usuário-pessoa-jurídica." (AZEVEDO, Fernando Costa de. A suspensão do fornecimento de serviço público essencial por inadimplemento do consumidor-usuário. Argumentos doutrinários e entendimento jurisprudencial. Revista de Direito do Consumidor, São Paulo, v. 62, abr./jun. 2007, p. 120).

${ }^{219}$ BRASIL. Superior Tribunal de Justiça. Primeira Seção. EREsp 845982/RJ. Rel. Min. Luiz Fux. Julgamento em 24/06/2009. Disponível em http://www.stj.jus.br. Acesso em 10/12/2010.

${ }^{220}$ BRASIL. Superior Tribunal de Justiça. Segunda Turma. AgRg no Ag 1329795/CE. Rel. Min. Herman Benjamin. Julgamento em 19/10/2010. Disponível em http://www.stj.jus.br. Acesso em 08/02/2011. Neste sentido, a Corte Especial do Superior Tribunal de Justiça já se havia pronunciado: "SUSPENSÃO DOS EFEITOS DE MEDIDA LIMINAR. CORTE DO FORNECIMENTO DE ÁGUA A ÓRGÃOS DE PREFEITURA MUNICIPAL, POR FALTA DE PAGAMENTO. Mesmo quando o consumidor é órgão público, o corte do fornecimento de água está autorizado por lei sempre que resultar da falta injustificada de pagamento, e desde que não afete a prestação de serviços públicos essenciais, v.g., hospitais, postos de saúde, creches, escolas; caso em que só os órgãos burocráticos foram afetados pela medida. Agravo regimental provido." (BRASIL. Superior Tribunal de Justiça. Côrte Especial. AgRg na SS 1764/PB. Rel. Min. Barros Monteiro. Julgamento em 27/11/2008). Identicamente: BRASIL. Superior Tribunal de Justiça. Segunda Turma. AgRg no REsp 1003667/RS. Rel. Min. Humberto Martins. Julgamento em 19/05/2009. Disponível em http://www.stj.jus.br. Acesso em 24/08/2010. 
inadimplemento do usuário, quando existir o interesse da coletividade. Para o autor, havendo inadimplência da Administração relativamente a hospitais, escolas, delegacias de polícia, etc., a concessionária não poderá interromper o fornecimento, dada a prevalência, no caso, do interesse da coletividade. ${ }^{221-222}$

Se a lei subordinou, como de fato o fez, o direito de interrupção por inadimplemento ao interesse da coletividade, em situações como essas - de essencialidade extrema - o fornecedor ficaria impedido de suspender o fornecimento do serviço, justamente ante o evidente e irreparável prejuízo que a ausência da prestação do serviço causará à toda a sociedade.

${ }^{221}$ OLIVEIRA, José Carlos de. Código de Proteção e Defesa do Consumidor: doutrina jurisprudência - legislação complementar. Leme: LED, 1999, pp. 101-102.

${ }^{222}$ Celso Antônio Bandeira de Mello tem opinião análoga: "Em nosso entender, tratando-se de serviço de uma essencialidade extrema, como é o caso da água, de notória relevância para a saúde pública, ou mesmo de grande importância para a normalidade da vida atual, como os de eletricidade, nem o Poder Público ou o concessionário poderão cortá-los, se o usuário demonstrar insuficiência de recursos para o pagamento das contas mensais. Em tal caso, sua cobrança terá de ser feita judicialmente e só, aí, uma vez sopesadas as circunstâncias pelo juiz, é que caberá ou não o corte a ser decidido nesta esfera." (MELLO, Celso Antônio Bandeira. Curso de Direito Administrativo. 27. ${ }^{\text {a }}$ ed. São Paulo: Malheiros Editores, 2010, p. 746). Maria Antonieta Zanardo Donado pondera: "Não constitui infração do art. 22 do CDC o corte ou interrupção ao serviço público tarifado (água, gás, energia elétrica etc.), visto que tarifa é preço do serviço, que só aparece com a sua utilização. Destarte, não é ilegal a suspensão de seu fornecimento, desde que com aviso prévio, pela falta de pagamento, porque também nesse caso as empresas privadas que executassem serviço público não poderiam privar do serviço os usuários em mora (junho, 1992)." (DONADO, Maria Antonieta Zanardo. Proteção ao consumidor: conceito e extensão. São Paulo: Revista dos Tribunais, 1993, p. 129).

A seu turno, Newton de Lucca, responde à indagação se é lícito, por parte das concessionárias dos serviços públicos de energia elétrica, a interrupção do fornecimento do serviço em virtude do inadimplemento do usuário à luz do que dispõe o CDC, especialmente o art. 22, que alude, entre outras, à continuidade dos chamados serviços essenciais, salienta: "As empresas concessionárias podem e devem, em princípio, efetuar o corte de energia nas hipóteses de inadimplemento. Podem fazê-lo, em primeiro lugar, pelas simples e boa razão de que a continuidade do serviço essencial, prevista no CDC - e, mesmo antes deste último, em sede doutrinária - não significa continuidade em todas as hipóteses. Se assim se entendesse, com efeito, teríamos o absurdo de, por exemplo, ser impossível a interrupção mesmo para a reparação de um problema técnico...(...).

"Tais observações, todavia, não significam a aplicação do corte de forma absoluta. Sei que as concessionárias não praticam a medida contra hospitais, estabelecimentos escolares etc. Fazem-no, evidentemente, em atenção à peculiaridade de tais casos. Se eu fosse Juiz de Direito, posso responder que não vacilaria em conceder uma liminar contra o corte de fornecimento de energia em todas aquelas hipóteses em que direitos fundamentais de que são exemplos a saúde e a vida, pudessem ser atingidos." (LUCCA, Newton de. Direito do consumidor: aspectos práticos: perguntas e respostas. São Paulo: Revista dos Tribunais, 1995. pp. 165-166). 
É fato que a Lei de Concessões e Permissões (Lei 8.987/95) deixou de conceituar ou delimitar a expressão interesse da coletividade ${ }^{223}$ trazida na parte final do citado inc. II. Para a solução desse impasse, deve-se servir, por analogia à Lei de Greve, do referencial trazido pelo parágrafo único do art. 11 desta Lei, que assume como de interesse coletivo as atividades que atingem necessidades inadiáveis da comunidade, entendidas como "aquelas que, não atendidas, coloquem em perigo iminente a sobrevivência, a saúde ou a segurança da população.",224

Da análise dos textos acima referidos evidencia-se inexistir qualquer incompatibilidade ou antinomia entre o disposto no $\S 3 .^{\circ}$ do art. $6 .^{\circ}$, da Lei 8.987/1995 e o art. 22, do Código de Proteção e Defesa do Consumidor. Ademais, a Lei 8.987 tem caráter de lei especial em relação ao Código do Consumidor (lei geral), destinada que é à regulamentação dos serviços públicos prestados por agentes delegados, atraindo a solução dos parágrafos do art. 2. da Lei de Introdução ao Código Civil.

Em conclusão, tais preceitos (notadamente o $\S 3 .^{\circ}$ do art. $6 .^{\circ}$, da Lei 8.987/1995 e o art. 17, da Lei 9.427) não desdizem o significado e conteúdo do princípio da continuidade, nem o mitigam. Em realidade, tais preceitos - que, a nosso ver, harmonizam-se com perfeição com tal princípio - servem apenas e tão somente como cláusulas de conformação do princípio em estudo.

Como também se procurou frisar ao longo deste trabalho, a continuidade não é princípio absoluto, nem pode dar ensejo ao entendimento (incorreto) de uma permanência na sua prestação. Ao contrário, em dadas situações - as assim previstas em lei, que consideram com proporcionalidade e razoabilidade as situações - o princípio poderá ceder espaço, sem incorrer em qualquer inconstitucionalidade.

\footnotetext{
${ }^{223}$ Expressão que, para nós, equivale a interesse público.

${ }^{224} \mathrm{Na}$ mesma direção: BRASIL. Superior Tribunal de Justiça. Primeira Seção. EREsp 845982/RJ. Rel. Min. Luiz Fux. Julgamento em 24/06/2009. Disponível em http://www.stj.jus.br. Acesso em 06/09/2010.
} 
Com absoluto acerto, pontifica Luiz Alberto Blanchet que a proteção do princípio da permanência do serviço público abrange exclusivamente "aqueles que se encontram em situação juridicamente protegida, e o consumidor inadimplente evidentemente não se encontra em tal situação, inclusive em função do princípio da igualdade dos usuários perante o prestador do serviço."225

Em função de tudo o que se expôs, não há lugar para outra conclusão senão que pela plena constitucionalidade e legalidade do inciso II do $\S 3 .^{\circ}$ do art. $6^{\circ}$, da Lei $8.987 / 95$, em particular em face dos princípios da razoabilidade e proporcionalidade.

A proporcionalidade tem sido entendida como a imprescindibilidade de que nenhuma medida administrativa seja mais drástica do que o necessário a fim de se atingir o resultado almejado. $\mathrm{O}$ que se vê da disciplina da Lei 8.987 é, justamente, a adoção de pequenas restrições (para nós, conformações) à garantia da continuidade, limitações essas que estão contidas e sempre estiveram - em seu próprio significado.

$\mathrm{O}$ mesmo deve-se dizer quanto à razoabilidade (braço ou faceta da proporcionalidade): todos os textos legais estudados, em particular o inc. II do $\S$ 3. ${ }^{\circ}$ do art. $6^{\circ}$, da Lei 8.987/95, preveem com razoabilidade da interrupção do fornecimento de serviço, considerando o não cumprimento do contratado por parte do usuário - e, ainda assim, dada a particularidade ou excepcionalidade da situação ou dos envolvidos, impedindo a suspensão do serviço. ${ }^{226-227}$

\footnotetext{
${ }^{225}$ BLANCHET, Luiz Alberto. Concessão e Permissão de Serviços Públicos. Curitiba: Juruá, 1995, p. 41.

${ }^{226}$ GRAU, Eros Roberto. Suspensão do fornecimento de energia elétrica: constitucionalidade, Código do Consumidor, princípios e postulados normativos aplicativos da razoabilidade e da proporcionalidade, Revista Trimestral de Direito Público, São Paulo, v. 36, 2001, p. 147.

${ }^{227}$ O Superior Tribunal de Justiça em mais de uma oportunidade reconheceu a legitimidade da interrupção sob a ótica do princípio da proporcionalidade. Assim: "Destoa do arcabouço lógicojurídico que informa o princípio da proporcionalidade o entendimento de que, a pretexto de resguardar os interesses do usuário inadimplente, cria embaraços às ações implementadas pela fornecedora de energia elétrica com o propósito de favorecer o recebimento de seus créditos, prejudicando, em maior escala, aqueles que pagam em dia as suas obrigações. 3. Se a empresa
} 
Ao mesmo tempo em que se sustenta a ilegitimidade de invocação do princípio da continuidade por parte do usuário na tentativa de justificar a não suspensão do fornecimento, se não está em dia com suas obrigações (isto é, com o pagamento da remuneração pelo serviço, prevista e assegurada no $\S 3 .^{\circ}$ do art. 6. ${ }^{\circ}$ da Lei 8.987), impede-se o prestador de suspender o fornecimento se ficar evidenciado um interesse da coletividade, hábil a justificar (ou exigir) a manutenção e a continuidade dos serviços.

Portanto, pelas mesmas razões, não se vislumbra na solução apontada afronta alguma ao princípio da dignidade da pessoa humana (este, de inegável assento constitucional - cf. art. 1, CF), justamente pela ponderação de valores proposta.

O mesmo raciocínio - chegando-se às mesmas conclusões, é dizer, por sua compatibilidade - há de ser feito quanto à constitucionalidade e legalidade do disposto no art. 17, da Lei 9.427/1996 aos valores e garantias constitucionais acima examinadas, por tudo o que se expôs nas linhas anteriores.

deixa de ser, devida e tempestivamente, ressarcida dos custos inerentes às suas atividades, não há como fazer com que os serviços permaneçam sendo prestados com o mesmo padrão de qualidade. Tal desequilíbrio, uma vez instaurado, reflete, diretamente, na impossibilidade prática de observância do princípio expresso no art. 22, caput, do Código de Defesa do Consumidor. 4. Recurso especial provido." (BRASIL. Superior Tribunal de Justiça. Segunda Turma. REsp 601131/MS. Rel. Min. João Otávio de Noronha. Julgamento em 27/03/2007. Disponível em http://www.stj.jus.br. Acesso em 10/12/2010.). No mesmo norte, enfrentando a questão à luz dos princípios da proporcionalidade e, também, da razoabilidade, v. os seguintes acórdãos: BRASIL. Superior Tribunal de Justiça: REsp 811690/RR. Rel. Min. Denise Arruda. Julgamento em 18/05/2006; REsp 796808/RN. Rel. Min. Denise Arruda. Julgamento em 16/05/2006 e REsp 682378/RS. Rel. Min. João Otávio de Noronha. Julgamento em 20/04/2006. Disponível em http://www.stj.jus.br. Acesso em 10/12/2010. 


\subsection{A excecptio non adimplenti contratus e o serviço público}

Os comentários até aqui expendidos exigem o enfrentamento de mais uma questão, envolvendo a aplicabilidade do princípio da exceptio non adimpleti contratus ${ }^{228}$ em situações de descumprimento de cláusulas contratuais no âmbito dos contratos de concessão de serviço público.

Por essa regra classicamente aplicada às relações privadas, nenhum dos contratantes pode antes de cumprida sua obrigação, exigir a do outro e, assim, detém o direito de alegar em seu favor a execução de contrato não cumprido. É o que se lê no art. 476, do Código Civil: "Nos contratos bilaterais, nenhum dos contratantes, antes de cumprida a sua obrigação, pode exigir o implemento da do outro."

Examinada a questão sob a ótica do princípio da continuidade dos serviços públicos, indaga-se então se a exceptio pode ser invocada e aplicada à Administração nas hipóteses de inadimplência do particular. E mais: se o princípio da continuidade, neste contexto, poderia justificar - ou de qualquer modo exigir - a inaplicabilidade à Administração da exceptio, sob o argumento de que o serviço é público e, portanto, dotado de prerrogativas especiais.

De fato, a teoria clássica do contrato administrativo firmou entendimento no sentido de que o contratado não poderia invocar $o$ descumprimento do contrato, por parte da Administração Pública, e, sob este argumento, eximir-se do cumprimento de seus encargos.

${ }^{228} \mathrm{Ou}$, no vernáculo, exceção de contrato não cumprido. 
Essa assertiva, porém, além de passar longe do consenso doutrinário, nunca foi completamente correta, anota Ana Maria Goffi Flaquer Scartezzini. ${ }^{229}$

Com efeito, a orientação pela inoponibilidade absoluta, rigorosamente prejudicial aos particulares, não podia persistir - ao menos, não sem exceções - pois permitiria que, em algumas situações, a exigência da continuidade na prestação em favor da Administração viesse a comprometer a própria "atividade desenvolvida pelo particular, a ponto de levá-lo a quebra."230

Felizmente, o advento da Lei de Licitações (Lei 8.666/93) teve o condão de atenuar o problema, prevendo a possibilidade da oposição, por parte do particular, da cláusula da exceptio, nas situações ali descritas. Consta do art. 78 de referida lei, in verbis: “Art. 78. Constituem motivo para rescisão do contrato: (...) XV - o atraso superior a 90 (noventa) dias dos pagamentos devidos pela Administração decorrentes de obras, serviços ou fornecimento, ou parcelas destes, já recebidos ou executados, salvo em caso de calamidade pública, grave perturbação da ordem interna ou guerra, assegurado ao contratado o direito de optar pela suspensão do cumprimento de suas obrigações até que seja normalizada a situação."

Exigir o cumprimento do contrato por parte do particular, em qualquer situação, ou seja, "mesmo quando a Administração não cumpre o avençado, implica em enriquecimento sem causa para o Poder Público em detrimento do particular."231 É opinião que se tem por correta e permite-se acompanhar.

\footnotetext{
${ }^{229}$ SCARTEZZINI, Ana Maria Goffi Flaquer. O princípio da continuidade do serviço público. São Paulo: Malheiros Editores, 2006, p. 106.

${ }^{230}$ Ibidem, mesma página.

${ }^{231}$ Ibidem, mesma página.
} 


\subsection{O equilíbrio econômico-financeiro do contrato de concessão}

Incontroverso o reconhecimento da posição de prevalência que ostenta a Administração nos contratos administrativos, posição essa que decorre, em larga escala, dos princípios guias da relação jurídica administrativa e sobre os quais nos debruçamos no Capítulo 2, deste trabalho (supra). As atividades da Administração direcionam-se à realização do interesse público, característica que parece explicar o feixe de prerrogativas que lhe são conferidas.

Dentre tais prerrogativas, uma delas requer particular cuidado e reflexão, neste momento. Referimo-nos à prerrogativa de mutabilidade e alteração unilateral do contrato por parte da Administração, sintetizada na faculdade que esta goza de inovar, alterando e adaptando as estipulações contratuais de molde a fazer frente às novas exigências e necessidades públicas.

Dentro dessa perspectiva, a Lei $8.666 / 93$ prevê em uma série de dispositivos, ao longo de seu texto, manifestações ou assentos de tal prerrogativa conferida à Administração Pública. De início, convém referir o texto do art. 58, inc. I, onde se lê: “Art. 58. O regime jurídico dos contratos administrativos instituído por esta Lei confere à Administração, em relação a eles, a prerrogativa de: I - modificá-los, unilateralmente, para melhor adequação às finalidades de interesse público, respeitados os direitos do contratado; (...).”

Além disso, prevê o art. 65, inc. I, da mesma lei, a alteração unilateral do contrato por parte da Administração, com a justificação devida: a) quando houver modificação do projeto ou das especificações, para melhor adequação técnica aos seus objetivos; b) quando necessária a modificação do valor contratual em decorrência de acréscimo ou diminuição quantitativa de seu objeto, nos limites permitidos pela Lei 8.666/93. 
Entretanto, o exercício do direito da Administração à alteração unilateral dos contratos não é absoluto, encontrando como limite a garantia do equilíbrio econômico-financeiro. ${ }^{232}$ Isso significa, em um primeiro momento, a necessidade de atenção à reciprocidade de direitos e obrigações entre as partes contratantes, com vistas ao desejado equilíbrio da relação contratual e que será observada a proporção verificada entre os encargos do contratado e a sua remuneração no momento da contratação, e que há de perdurar ao longo de toda a vigência do contrato. ${ }^{233}$

Demonstração inequívoca da importância e do peso da garantia do equilíbrio econômico-financeiro nos contratos de concessão nos é dada pela previsão, na própria Lei de Licitações, da necessidade de respeito aos direitos dos contratados: é o que se lê, assim, na parte final do inciso I do art. 58, acima citado. $^{234} \mathrm{O}$ chamado equilíbrio econômico financeiro vem garantido, ainda, nos $\S \S 1 .^{\circ}$ e $2 .^{\circ}$ do art. $58^{235}$ e no $\S 6 .^{\circ}$ do art. $65^{236}$, todos da Lei $8.666 / 93$, dentre outros dispositivos, bem como no art. 9. , parágrafos, da Lei 8.98795. ${ }^{237}$

\footnotetext{
${ }^{232}$ Também denominada 'equação financeira do contrato.'

${ }^{233}$ MEDAUAR, Odete. Direito Administrativo Moderno, 11. a ed. rev., atual. e ampl. São Paulo: Revista dos Tribunais, 2007, p. 213.

${ }^{234}$ Antes disso, reconhece-se que a proteção dos contratados tem assento no próprio texto constitucional (cf. art. 175, parágrafo único, inc. III e art. 37, inc. XXI).

235 In verbis: "§ $1 .^{\circ}$. As cláusulas econômico-financeiras e monetárias dos contratos administrativos não poderão ser alteradas sem prévia concordância do contratado." $§ 2 .{ }^{\circ}$. Na hipótese do inciso I deste artigo, as cláusulas econômico-financeiras do contrato deverão ser revistas para que se mantenha o equilíbrio contratual."

${ }^{236}$ In verbis: "§ $6 .^{\circ}$. Em havendo alteração unilateral do contrato que aumente os encargos do contratado, a Administração deverá restabelecer, por aditamento, o equilíbrio econômicofinanceiro inicial."

${ }^{237}$ In verbis: "Art. 9. ${ }^{\circ}$. A tarifa do serviço público concedido será fixada pelo preço da proposta vencedora da licitação e preservada pelas regras de revisão previstas nesta Lei, no edital e no contrato. § 1 . $^{\circ}$. A tarifa não será subordinada à legislação específica anterior e somente nos casos expressamente previstos em lei, sua cobrança poderá ser condicionada à existência de serviço público alternativo e gratuito para o usuário. (Redação dada ao parágrafo pela Lei n. ${ }^{\circ}$ 9.648, de 27.05.1998). $\S 22^{\circ}$. Os contratos poderão prever mecanismos de revisão das tarifas, a fim de manter-se o equilíbrio econômico-financeiro. $\S 3^{\circ}$. Ressalvados os impostos sobre a renda, a criação, alteração ou extinção de quaisquer tributos ou encargos legais, após a apresentação da proposta, quando comprovado seu impacto, implicará a revisão da tarifa, para mais ou para menos, conforme o caso. $\S 44^{\circ}$. Em havendo alteração unilateral do contrato que afete o seu inicial equilíbrio econômico-financeiro, o poder concedente deverá restabelecê-lo, concomitantemente à alteração."
} 
Celso Antônio Bandeira de Mello insere a exigência do equilíbrio econômico-financeiro como elemento integrante da própria definição de concessão de serviço público. ${ }^{238}$ Francisco Campos já sustentava, há muito, posição semelhante, entendendo a equação como causa da concessão, nos termos do que registra Caio Tácito. ${ }^{239}$

Para Eros Grau, a intangibilidade da equação "importa a impossibilidade de ser alterada, isoladamente, apenas uma das pontas da equação, seja a atinente aos encargos, seja a correspondente à retribuição do concessionário." 240

A regra da equação financeira não significa, destarte, inalterabilidade da tarifa, nem tampouco inalterabilidade das condições do serviço, mas sim que, mantendo-se a equação original, guardar-se-á a devida proporção entre uma (tarifa) e outra (condições do serviço). ${ }^{241}$

Postas essa premissas, podemos retomar a hipótese cogitada - de suspensão ou interrupção de serviço público essencial -, com o fito de averiguar se a inadimplência do usuário pode ser atribuída, de algum modo, à responsabilidade da concessionária. Permitimo-nos citar, ainda uma vez, a lição de Eros Grau, sobre a questão:

\footnotetext{
${ }^{238}$ MELLO, Celso Antônio Bandeira. Curso de Direito Administrativo. 27. ${ }^{\text {a }}$ ed. São Paulo: Malheiros Editores, 2010, p. 711.

${ }^{239}$ Cf. TÁCITO, Caio. Direito Administrativo. São Paulo: Saraiva, 1975, p. 233. Discorrendo sobre a mutabilidade unilateral da concessão (álea administrativa), Caio Tácito pontua: "A regra da equação financeira, 'segundo a qual os encargos do concessionário se devem compensar pelas vantagens', não é senão o outro prato da balança em que se coloca o privilégio do Estado de reformar as cláusulas regulamentares, mutáveis 'toda a vez que o interesse coletivo o exigir, porque têm por escopo a adequação do serviço às necessidades do público em geral.” (TÁCITO, Caio. Direito Administrativo. São Paulo: Saraiva, 1975, p. 236).

${ }^{240}$ GRAU, Eros Roberto. Suspensão do fornecimento de energia elétrica: constitucionalidade, Código do Consumidor, princípios e postulados normativos aplicativos da razoabilidade e da proporcionalidade, Revista Trimestral de Direito Público, São Paulo, v. 36, 2001, p. 148.

${ }^{241}$ Em última análise, a garantia do equilíbrio, aqui tratada, repercute igualmente no usuário (e não apenas no particular/concessionária), "pois ele também participa de forma incindível da relação jurídica formada pelo poder concedente e pelo concessionário." (SCARTEZZINI, Ana Maria Goffi Flaquer. O princípio da continuidade do serviço público. São Paulo: Malheiros Editores, 2006, p. 110).
} 
Daí porque esses efeitos [da inadimplência do usuário], desde que relevantes, conduziriam - se o concessionário estivesse obrigado a prestar o serviço ao usuário inadimplente - à necessidade de restaurar-se o equilíbrio econômico-financeiro do contrato, de modo que as perdas de remuneração suportadas pelo concessionário fossem compensadas por elevação tarifária que distribuísse entre os usuários pagantes do serviço a responsabilidade por aqueles efeitos. ${ }^{242}$

\subsection{O direito de greve, os serviços públicos essenciais e o princípio da continuidade}

Se se afirma que, pelo princípio da continuidade a Administração está impedida de - ao menos legitimamente - interromper suas atividades, que haverão de ser prestadas regular e continuamente, dois pontos merecem reflexão. O primeiro deles diz respeito à greve nos serviços públicos, cuja vedação sempre foi entendida por absoluta, mas que, atualmente, tem sua configuração bastante abrandada, procurando-se conciliar o direito de greve com a necessidade do serviço. De outro lado, serão examinados também institutos como a suplência, a delegação, a interinidade e a substituição como instrumentos eficazes à garantia da manutenção e continuidade da Administração (item 4.3, infra).

Compete-nos, neste momento, examinar a possibilidade de conciliação do princípio da continuidade com o direito de greve dos servidores públicos, garantido pelo art. 37, inc. VII da Constituição Federal e a ser exercido "na forma da lei".

\footnotetext{
${ }^{242}$ GRAU, Eros Roberto. Suspensão do fornecimento de energia elétrica: constitucionalidade, Código do Consumidor, princípios e postulados normativos aplicativos da razoabilidade e da proporcionalidade, Revista Trimestral de Direito Público, São Paulo, v. 36, 2001, p. 148.
} 
De início, importa ter presente que a Constituição Federal assegura o direito de greve aos trabalhadores, ressalvando, contudo, as situações de serviços ou atividades essenciais, em relação às quais se exige "o atendimento das necessidades inadiáveis da comunidade”, o que seria definido por lei específica. ${ }^{243}$

$\mathrm{O}$ art. 10 da Lei que ficou conhecida como a "Lei de Greve" (n. $7.783 / 89)^{244}$, diversas vezes mencionada ao longo deste trabalho, cumpriu essa missão e regulamentou o texto constitucional e definiu os serviços ou atividades, tais como o tratamento e abastecimento de água; distribuição de energia, gás e combustíveis; assistência médica e hospitalar; telecomunicações; compensação bancária, dentre outros.

\subsubsection{A greve no funcionalismo público e a jurisprudência do Supremo Tribunal Federal}

Não é de hoje que se desenrolam inúmeras controvérsias acerca do art. 37, VII, da Constituição Federal de 1988 que garante o direito de greve aos servidores públicos.

\footnotetext{
243 “Art. 9..$^{\circ}$ É assegurado o direito de greve, competindo aos trabalhadores decidir sobre a oportunidade de exercê-lo e sobre os interesses que devam por meio dele defender. $\S 1 .^{\circ}-$ A lei definirá os serviços ou atividades essenciais e disporá sobre o atendimento das necessidades inadiáveis da comunidade. $\S 2 .^{\circ}-$ Os abusos cometidos sujeitam os responsáveis às penas da lei."

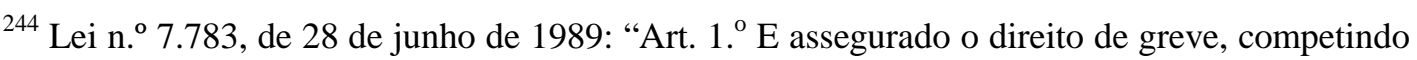
aos trabalhadores decidir sobre a oportunidade de exercê-lo e sobre os interesses que devam por meio dele defender. Parágrafo único. O direito de greve será exercido na forma estabelecida nesta Lei. Art. 2. ${ }^{\circ}$ Para os fins desta Lei, considera-se legítimo exercício do direito de greve a suspensão coletiva, temporária e pacífica, total ou parcial, de prestação de serviços a empregador."
} 
Tamanha celeuma encontra explicação facilmente: primeiro, porque referido dispositivo da Constituição Federal está - até os dias atuais - a depender de regulamentação por lei; segundo porque, a se permitir a greve na Administração Pública, estar-se-ia confrontando com o princípio da continuidade do serviço público.

A tudo isso se há de somar que o assunto (greve no funcionalismo público) sempre foi alvo de críticas contundentes, no sentido de que não se poderia garantir o direito de greve a tais servidores, tendo em vista as inúmeras vantagens e garantias que os mesmos já detêm.

Assim é que essa imagem histórica dos servidores públicos somada a imensa demora na regulamentação do art. 37, VII, da Constituição Federal viria a criar grandes dúvidas e percalços na aplicação da referida norma.

Do mesmo modo veio a contribuir sobremaneira para a verdadeira confusão interpretativa da norma a maneira pela qual o Poder Judiciário, desde o início da vigência da Constituição de 1988, negou-se a dar aplicabilidade à norma constitucional em comento, exigindo, até pouco tempo atrás, que a mesma fosse regulamentada.

Oswaldo Aranha Bandeira de Mello já lecionava sobre o direito de greve de servidores públicos, aduzindo que:

"O funcionário está obrigado a prestar os seus serviços em forma contínua, porque as atividades públicas não toleram interrupções. Portanto, a ausência sem a competente autorização ou justificação constitui falta, sujeita a penalidade administrativa. Consequentemente, o abandono coletivo, e por deliberação conjunta, do trabalho, por um grupo de funcionários, como atitude de rebeldia a comportamento do superior, com o objetivo de forçá-lo à prática de ato ou modificar o anterior, ou seja, a greve, constitui atitude ainda mais grave, suscetível de penalidades administrativa e penal. ${ }^{245}$

245 MELLO, Oswaldo Aranha Bandeira de. Princípios Gerais de Direito Administrativo, Volume II. Rio de Janeiro: Forense, 1974, pp. 461-462. 
Assim é que, mesmo diante de todas as investidas do Estado para impedi-las, as greves dos servidores públicos persistiriam e ainda persistem entre nós, remanescendo a necessidade de se enfrentar a questão a despeito da ausência de regulamentação ao preceito constitucional.

Primeiramente foi o Supremo Tribunal Federal que no julgamento do Mandado de Injunção n. ${ }^{\circ}$ 20/DF acabou por estabelecer a necessidade de se regulamentar o dispositivo constitucional.

Seguiram-se os julgamentos dos Mandados de Injunção n. ${ }^{\circ} \mathrm{s}$ 670/ES, 708/PB e 712/DF, no âmbito dos quais se reconheceu que a Lei n. ${ }^{\circ}$ 7.783/89 - regulamentadora do direito de greve para os trabalhadores - poderia ser aplicada aos servidores públicos naquilo que não confrontasse com a natureza estatutária do vínculo que tais servidores mantêm com o Estado.

Com isso põe-se em relevo verificar até que ponto o regime trazido pela Lei $7.783 / 89$ pode ser aplicado aos movimentos grevistas dos servidores públicos e, para o que interessa nuclearmente a este trabalho, como harmonizar esse entendimento com o princípio da continuidade.

De fato, a referência à greve no âmbito do serviço público é preceito que, de maneira inovadora, constou do texto da Constituição da República de 1988. Antes disso, nem mesmo o direito à greve dos trabalhadores em geral foi assegurado nos sucessivos textos constitucionais do direito brasileiro. Após ter sido expressamente proibida no texto outorgado em 1937, a Constituição de 1946, garantiu o direito de greve no âmbito do seu art. 158: "é reconhecido o direito de greve, cujo exercício a lei regulará."

Mais adiante a Constituição de 1967 reconheceu o direito à greve, o que foi mantido pela emenda de 69, com a ressalva, porém, de sua impossibilidade nos serviços públicos e atividades essenciais, 'assim definidas em lei’. A Constituição da República de 1988 deu um passo adiante: além de 
assegurar o direito de greve no rol dos direitos sociais, inovou significativamente ao estender tal direito aos servidores públicos civis (com a vedação para os militares). Todavia, previu que o exercício de tal direito dependeria de regulamentação por lei complementar.

Entretanto, como a lei complementar mencionada no aludido art. 37, VII não foi editada, essa questão veio a ser submetida ao Supremo Tribunal Federal por intermédio do Mandado de Injunção n. ${ }^{\circ}$ 20/DF, impetrado pela Confederação dos Servidores Públicos do Brasil.

Na ocasião, o STF reconheceu a eficácia limitada do art. 37, VII, e, por consequência, a mora do Poder Legislativo. Fixou também, na ocasião, o entendimento de que enquanto não editada a lei regulamentadora, os servidores públicos não teriam direito à greve (ou melhor, não teriam como exercitar tal direito).

Em trecho expressivo da ementa desse julgado, consigna-se:

"O preceito constitucional que reconheceu o direito de greve ao servidor público civil constitui norma de eficácia meramente limitada, desprovida, em consequência, de auto-aplicabilidade, razão pela qual, para atuar plenamente, depende da edição da lei complementar exigida pelo próprio texto da Constituição. A mera outorga constitucional do direito de greve ao servidor público civil não basta - ante a ausência de auto-aplicabilidade da norma constante do art. 37, VII, da Constituição - para justificar o seu imediato exercício. O exercício do direito público subjetivo de greve outorgado aos servidores civis só se revelará possível depois da edição da lei complementar reclamada pela Carta Política. A lei complementar referida - que vai definir os termos e os limites do exercício do direito de greve no serviço público - constitui requisito de aplicabilidade e de operatividade da norma inscrita no art. 37, VII, do texto constitucional. Essa situação de lacuna técnica, precisamente por inviabilizar o exercício do direito de greve, justifica a utilização e o deferimento do mandado de injunção. A inércia estatal configura-se, objetivamente, quando o excessivo e irrazoável retardamento na efetivação da prestação legislativa - não obstante a ausência, na 
Constituição, de prazo pré-fixado para a edição da necessária norma regulamentadora - vem a comprometer e a nulificar a situação subjetiva de vantagem criada pelo texto constitucional em favor dos seus beneficiários." $246-247$

No acórdão em referência, como se vê à evidência, ficou reconhecida à abundância a imperiosidade de uma prestação contínua e ininterrupta por parte da Administração Pública (ou por quem lhe faça as vezes, como é natural), no âmbito dos serviços públicos. Registrou-se, enfim, que o direito à greve haveria de ser lido e sopesado ao lado de outros preceitos, em particular os princípios já examinados neste trabalho da preponderância dos interesses públicos e da continuidade do serviço público, entendimento este que norteou o julgamento do Mandado de Injunção referido.

A este julgamento emblemático da questão - e ante o entendimento assentado pelo STF - seguiram-se o ajuizamento de Ações Diretas de Inconstitucionalidade (tais como ADIs n. 1.696/SE e 1.306/BA), contestando o texto do art. 37, inc. VII, em face de uma afirmada invasão de competência legislativa e, com isso, afronta à partilha constitucional de competências (arts. 21 e ss, CF). Tais ações não lograram o desejado êxito, entretanto.

Tenha-se presente, neste contexto, que no ano de 1998 veio a lume a Emenda Constitucional de n. ${ }^{\circ}$ 19, a qual imprimiu significativa alteração redacional ao art. 37, inc. VII, excluindo a expressão 'complementar'; com isto, franqueou a possibilidade dessa regulamentação ocorrer por intermédio de lei ordinária.

\footnotetext{
${ }^{246}$ BRASIL. Supremo Tribunal Federal. MI n. 20, Relator Min. Celso de Mello. Plenário. DJ de 22/11/1996, p. 45.690. Disponível em http://www.stf.jus.br. Acesso em 25/08/2010.

${ }^{247}$ A orientação firmada pelo STF, limitando o objeto do Mandado de Injunção à declaração da existência, ou não, de mora legislativa para a edição de norma regulamentadora, foi reiterada no julgamento do MI 585/TO, Rel. Min. Ilmar Galvão, DJ 02/08/2002 e do MI 485/MT, Rel. Min. Maurício Corrêa, DJ 23/08/2002 (BRASIL. Supremo Tribunal Federal. MI 585/TO, Rel. Min. Ilmar Galvão, DJ 02/08/2002 e do MI 485/MT, Rel. Min. Maurício Corrêa, DJ 23/8/2002 Disponível em http://www.stf.jus.br. Acesso em 25/08/2010).
} 
Entretanto, conquanto o julgamento do MI n. ${ }^{\text {o }}$ 20/DF tivesse reconhecido a mora legislativa para a edição da norma regulamentadora específica, nada se alterou na prática, persistindo a ausência de regulamentação do tema por intermédio da edição de lei (agora ordinária, e não mais complementar, em função da alteração implementada pela Emenda Constitucional 19/98). Ao ensejo da persistente mora, o Supremo Tribunal Federal foi novamente convidado a examinar o problema. Mas agora, por ocasião do julgamento dos Mandados de Injunção n. ${ }^{\circ}$ s 670/ES, 708/PB e 712/DF, a orientação anterior daquela Excelsa Corte foi revista, alterando-se significativamente o entendimento do Supremo Tribunal Federal a respeito do tema.

Dando um passo à frente e avançando de forma substancial no que diz respeito à clássica compreensão, até então reconhecida, do limite e do objeto do Mandado de Injunção, em uma dessas oportunidades mais recentes, o STF fez consignar que a mora legislativa em questão já havia sido declarada por diversas vezes e que "a permanência da situação de ausência de regulamentação do direito de greve dos servidores públicos civis passa a invocar, para si, os riscos de consolidação de uma típica omissão judicial. (...)."248

Enfrentando o tema nuclear, ou seja, se o direito de greve dos servidores públicos poderia se "aproveitar" da disciplina constante da Lei de Greve dos Trabalhadores em geral, o voto condutor do Min. relator deixou claro, em primeiro plano, o reconhecimento de que a aplicação dessa legislação ao caso específico do direito de greve dos servidores públicos deixava manifesto "o conflito existente entre as necessidades mínimas de legislação para o exercício do direito de greve dos servidores públicos civis (CF, art. 9. ${ }^{\circ}$, caput, c/c art. 37,

248 BRASIL. Supremo Tribunal Federal. Mandado de Injunção n. ${ }^{\circ}$ 670/ES. Relator originário Min. Maurício Corrêa. Relator p/ Acórdão: Min. Gilmar Mendes. Julgamento: 25/10/2007. Disponível em http://www.stf.jus.br. Acesso em 25/08/2010. 
VII), de um lado, e o direito a serviços públicos adequados e prestado s de forma contínua a todos os cidadãos (CF, art. 9. $\left.{ }^{\circ}, \S 1 .^{\circ}\right)$, de outro". 249

Desta feita, considerada a reiterada omissão legislativa, o STF decidiu pelo acolhimento da pretensão manifestada naquele Mandado de Injunção, para o fim de que fosse aplicada a Lei n. ${ }^{\circ}$ 7.783/1989 enquanto persistisse a omissão na regulamentação do art. 37, VII. Vale transcrever, por absolutamente oportuno, trecho significativo da ementa do acórdão:

“4.3 Em razão dos imperativos da continuidade dos serviços públicos, contudo, não se pode afastar que, de acordo com as peculiaridades de cada caso concreto e mediante solicitação de entidade ou órgão legítimo, seja facultado ao tribunal competente impor a observância a regime de greve mais severo em razão de tratar-se de "serviços ou atividades essenciais", nos termos do regime fixado pelos arts. 9. a 11 da Lei no 7.783/89. Isso ocorre porque não se pode deixar de cogitar dos riscos decorrentes das possibilidades de que a regulação dos serviços públicos que tenham características afins a esses "serviços ou atividades essenciais" seja menos severa que a disciplina dispensada aos serviços privados ditos "essenciais". 4.4. O sistema de judicialização do direito de greve dos servidores públicos civis está aberto para que outras atividades sejam submetidas a idêntico regime. Pela complexidade e variedade dos serviços públicos e atividades estratégicas típicas do Estado, há outros serviços públicos, cuja essencialidade não está contemplada pelo rol dos arts. 9. ${ }^{\circ}$ a 11 da Lei no 7.783/89. Para os fins desta decisão, a enunciação do regime fixado pelos arts. 9. ${ }^{\circ}$ a 11 da Lei no 7.783/89 é apenas exemplificativa (numerus apertus).

Constou ademais, da ementa que,

${ }^{249}$ BRASIL. Supremo Tribunal Federal. Mandado de Injunção no 670/ES. Relator originário Min. Maurício Corrêa. Relator p/ Acórdão: Min. Gilmar Mendes. Julgamento: 25/10/2007. Disponível em http://www.stf.jus.br. Acesso em 25/08/2010. 
"A adequação e a necessidade da definição dessas questões de organização e procedimento dizem respeito a elementos de fixação de competência constitucional de modo a assegurar, a um só tempo, a possibilidade e, sobretudo, os limites ao exercício do direito constitucional de greve dos servidores públicos, e a continuidade na prestação dos serviços públicos. Ao adotar essa medida, este Tribunal passa a assegurar o direito de greve constitucionalmente garantido no art. 37, VII, da Constituição Federal, sem desconsiderar a garantia da continuidade de prestação de serviços públicos - um elemento fundamental para a preservação do interesse público em áreas que são extremamente demandadas pela sociedade. 6.6. Em razão da evolução jurisprudencial sobre o tema da interpretação da omissão legislativa do direito de greve dos servidores públicos civis e em respeito aos ditames de segurança jurídica, fixa-se o prazo de 60 (sessenta) dias para que o Congresso Nacional legisle sobre a matéria. 6.7. Mandado de injunção conhecido e, no mérito, deferido para, nos termos acima especificados, determinar a aplicação das Leis nos 7.701/88 e 7.783/89 aos conflitos e às ações judiciais que envolvam a interpretação do direito de greve dos servidores públicos civis."250

O Supremo Tribunal Federal firmou a mesma orientação no julgamento do Mandado de Injunção n. ${ }^{\circ}$ 708/PB e do Mandado de Injunção n. ${ }^{\circ}$ 712/DF, julgados simultaneamente (e firmadas as mesmas conclusões) com o MI 670/ES.

${ }^{250}$ BRASIL. Supremo Tribunal Federal. Mandado de Injunção n. ${ }^{\circ}$ 670/ES. Relator originário Min. Maurício Corrêa. Relator p/ Acórdão: Min. Gilmar Mendes. Julgamento: 25/10/2007. Disponível em http://www.stf.jus.br. Acesso em 25/08/2010. 


\subsubsection{A greve dos servidores públicos e o princípio da continuidade}

Dentro do contexto acima delineado, emergem duas questões a serem respondidas. A primeira delas consistente em saber se a Lei de Greve aplica-se aos servidores públicos, indagação que se responde com o entendimento assumido pelo Supremo Tribunal Federal, quando se debruçou no julgamento da matéria. A segunda questão - quiçá mais complexa - diz respeito à tarefa de (tentar) harmonizar os preceitos e postulados acima trazidos, de molde a assegurar a possibilidade do exercício do direito constitucional de greve dos servidores públicos, preservando-se, porém, a continuidade na prestação dos serviços públicos, notadamente dos essenciais.

Como ponto de partida para a solução das questões apresentadas, referimos manifestação emblemática do Supremo Tribunal Federal, em acórdão de relatoria do Min. Eros Grau e no âmbito da qual se procurou estabelecer a amplitude da decisão proferida no julgamento do Mandado de Injunção n. ${ }^{\circ} 712$. Registrou-se, assim, nos autos da Reclamação n. ${ }^{\circ}$ 6.568/SP ${ }^{251}$, que no MI 712 foi decidido que "o direito de greve está, sim, integrado ao patrimônio jurídico dos servidores públicos. Dada a índole das atividades que exercem, não é, todavia, absoluto."

\footnotetext{
${ }^{251}$ Em acórdão assim ementado: "RECLAMAÇÃO. SERVIDOR PÚBLICO. POLICIAIS CIVIS. DISSÍDIO COLETIVO DE GREVE. SERVIÇOS OU ATIVIDADES PÚBLICAS ESSENCIAIS. COMPETÊNCIA PARA CONHECER E JULGAR O DISSÍDIO. ARTIGO 114, INCISO I, DA CONSTITUIÇÃO DO BRASIL. DIREITO DE GREVE. ARTIGO 37, INCISO VII, DA CONSTITUIÇÃO DO BRASIL. LEI N. 7.783/89. INAPLICABILIDADE AOS SERVIDORES PÚBLICOS. DIREITO NÃO ABSOLUTO. RELATIVIZAÇÃO DO DIREITO DE GREVE EM RAZÃO DA ÍNDOLE DE DETERMINADAS ATIVIDADES PÚBLICAS. AMPLITUDE DA DECISÃO PROFERIDA NO JULGAMENTO DO MANDADO DE INJUNÇÃO N. 712. ART. 142, § 3. , INCISO IV, DA CONSTITUIÇÃO DO BRASIL. INTERPRETAÇÃO DA CONSTITUIÇÃO. AFRONTA AO DECIDIDO NA ADI 3.395. INCOMPETÊNCIA DA JUSTIÇA DO TRABALHO PARA DIRIMIR CONFLITOS ENTRE SERVIDORES PÚBLICOS E ENTES DA ADMINISTRAÇÃO ÀS QUAIS ESTÃO VINCULADOS. RECLAMAÇÃO JULGADA PROCEDENTE." (BRASIL. Supremo Tribunal Federal. Rcl 6568/SP, Relator Min. Eros Grau, Julgamento 21/05/2009. Disponível em http://www.stf.jus.br. Acesso em 25/08/2010.).
} 
$\mathrm{Na}$ verdade, o que se pretende esclarecer é que, quando se fala como no caso - da privação do bem comum, deve-se ter em mente que o direito de greve, embora legítimo, deve ser caracterizado como secundário em relação ao interesse da coletividade. Em outras palavras: o direito de greve dos servidores sempre e impreterivelmente condicionado e limitado pelo bem comum.

Refira-se, em igual direção, o julgamento do Mandado de

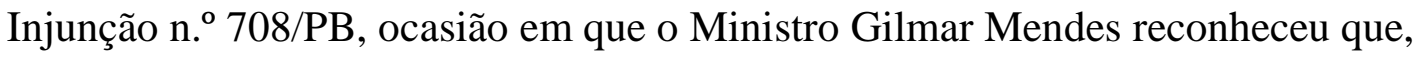
à vista dos imperativos da continuidade dos serviços públicos, "não estou a afastar que, de acordo com as peculiaridades de cada caso concreto e mediante a solicitação de órgão competente, seja facultado ao juízo competente impor a observância a regime de greve mais severo em razão de se tratarem de 'serviços ou atividades essenciais', nos termos dos já mencionados arts. 9. e 11 da Lei n. ${ }^{o} 7.783 / 1989 . ”$

Prossegue no voto o Ministro relator, acentuando que:

“... Os servidores públicos são, seguramente, titulares do direito de greve. Essa é a regra. Ocorre, contudo - disse-o então e não tenho pejo em ser repetitivo - que entre os serviços públicos há alguns que a coesão social impõe sejam prestados plenamente, em sua totalidade. Referia-me especialmente aos desenvolvidos por grupos armados. As atividades desenvolvidas pela polícia civil são análogas, para esse efeito, às dos militares, em relação aos quais a Constituição expressamente proíbe a greve [art. 142, § 3. ${ }^{\circ}$ IV].

14. É certo, além disso, que a relativização do direito de greve não se limita aos policiais civis. A exceção estende-se a outras categorias. Servidores públicos que exercem atividades das quais dependam a manutenção da ordem pública e a segurança pública, a administração da Justiça - o onde as carreiras de Estado, cujos membros exercem atividades indelegáveis, inclusive as de exação tributária - e a saúde pública não estão inseridos no elenco dos servidores alcançados por aquele direito. Aqui prevalecerá, a conformar nossa decisão, a doutrina do duplo efeito. (...) 
16. Estou a concluir este voto, para afirmar - e considero, neste passo, o que mencionou o reclamante, em relação à necessidade de esta Corte manifestar-se sobre a aplicação da lei de greve 'aos ocupantes de carreiras de Estado que exercem funções públicas essenciais' - para que a conservação do bem comum exige que certas categorias de servidores públicos sejam privadas do exercício do direito de greve. Em defesa dela - a conservação do bem comum - e para a efetiva proteção de outros direitos igualmente salvaguardados pela Constituição do Brasil."

Chega-se à conclusão, destarte, de que embora o direito de greve seja inerente ao trabalhador - e levando-se em conta que o servidor público não pode deixar de ser inserido na categoria dos trabalhadores -, não se pode negar a esta categoria a possibilidade de perseguir seus direitos através do movimento paredista.

Neste passo, afigura-se necessário averiguar em que medida a Lei 7.783/89 pode ser aplicada aos servidores públicos, sem que lhes seja negado o direito de greve mas que, ao mesmo tempo, mantenha-se incólume a continuidade do serviço público - preservando-se incólume, em última análise, o próprio interesse público perseguido na atividade administrativa.

Admite-se, pois, a greve dos servidores públicos desde prevaleça sempre o interesse da coletividade na medida em que o cidadão sofra a menor desvantagem possível. Ou seja, é imprescindível, no trato da matéria, um permanente sopesamento entre o interesse público, manifestado pelo interesse da coletividade, e os interesses de uma categoria de servidores-trabalhadores, prevalecendo sempre os interesses da coletividade. ${ }^{252}$

\footnotetext{
${ }^{252}$ Lembre-se que a Lei 7.783, de 28/6/89, além de definir os serviços essenciais em seu art. 10, estabelece que os sindicatos, empregados e trabalhadores ficam obrigados, de comum acordo, a garantir, durante a greve, a prestação desses serviços, desde que a greve coloque em perigo iminente a sobrevivência, a saúde ou a segurança da população (art. 11 e parágrafo único). Registre-se, ademais, que "caso a greve seja declarada ilegal, o sindicato poderá ser condenado a indenizar o prejuízo causado à população." (Odete Medauar. Direito Administrativo Moderno. 11. ${ }^{\text {a }}$ ed. rev., atual. e ampl. São Paulo: Revista dos Tribunais, 2007, p. 328).
} 
Portanto, em todas as situações em que o direito de greve dos servidores vier a ser contrastado com uma situação envolvendo serviços públicos essenciais - e não apenas os de essencialidade extrema ${ }^{253}$ - a paralisação não será legitimada. Aqui, diferentemente das conclusões assumidas quanto à interrupção do serviço por inadimplemento do usuário no item anterior, a verificação de estar-se diante de um serviço público essencial implicará em restrição legítima ao direito de greve.

Ana Maria Goffi Flaquer Scartezzini alinha-se a essa orientação. Aduz que se o serviço essencial, “o trabalhador por ele responsável sofre limitações no exercício de seus direitos, pois a ele incumbe a satisfação e direitos próprios da coletividade e que devem ser resguardados. „254

A garantia do princípio da continuidade dos serviços públicos exige, pois, restrição a determinados direitos dos prestadores de serviços públicos (para nós, como já se adiantou e mais amplamente se demonstrará logo, conformações), e, no particular, tais restrições projetam-se também nos agentes envolvidos em sua prestação. ${ }^{255}$

\footnotetext{
${ }^{253}$ Expressão que há de ser tomada com o significado assumido neste trabalho. Para tanto, remetemos o leitor ao Capítulo 1, supra.

${ }^{254}$ SCARTEZZINI. Ana Maria Goffi Flaquer. O Princípio da Continuidade do Serviço Público. São Paulo: Malheiros Editores, 2006, pp. 108-109. Ives Gandra Martins, em obra escrita em coautoria com Celso Bastos, tem opinião mais "inflexível", por assim dizer. "Tenho entendido" sustenta - "que o direito de greve é limitado às garantias outorgadas à sociedade pela Constituição. $\mathrm{O}$ direito ao trabalho é maior que o direito de greve, e o direito do cidadão a ter serviço prestado por funcionário do Estado também é maior que seu direito de greve. Ninguém é obrigado a ser servidor público. Se o for, entretanto, deve saber que a sua função oferece mais obrigações e menos direitos que na atividade privada. É que o servidor é antes de tudo um servidor da comunidade e não um servidor de si mesmo, sendo seus direitos condicionados aos seus deveres junto à sociedade." (MARTINS, Ives Gandra da Silva; BASTOS, Celso.

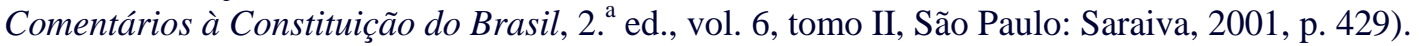

${ }^{255}$ O Superior Tribunal de Justiça - havido por competente para julgar o direito de greve de servidor público civil quando a paralisação for de âmbito nacional ou abrangente de mais de uma unidade da federação (competência esta fixada pelo STF ao apreciar simultaneamente os MI n. 670/ES, 708/DF e 712/PA - tem caminhado no sentido do reconhecimento da legalidade das paralisações, porém, com limitações. No julgamento liminar da Petição n. 7985, o Min. Humberto Martins asseverou: "A situação deve ser confrontada com os princípios da supremacia do interesse público e da continuidade dos serviços essenciais". De forma análoga, a Primeira Seção do STJ, no Agravo Regimental na Pet n. 7939/DF, avalizou entendimento da Corte Suprema, consignando em passagem da ementa deste julgado: “... O direito de greve no
} 
É bem verdade que a conciliação entre o direito de greve e a continuidade já se realiza por regras específicas, muitas delas previstas na Lei de Greve (comunicação prévia, com antecedência razoável, do início da greve; manutenção de parte das atividades em funcionamento). Mas, ao que tudo indica, mais do que isso, essa conciliação só será habilmente feita se se considerarem a marca de essencialidade e o interesse coletivo de alguns serviços públicos.

Se no âmbito do regime privado cogitar-se-ia da possibilidade da adoção de medidas aptas ao atendimento das "necessidades inadiáveis da comunidade" (cfe. os dizeres do parágrafo primeiro do art. 9, da CF), tal providência não parece de modo algum adequada - ou viável - no âmbito dos serviços públicos essenciais. ${ }^{256}$ Imagine-se, por hipótese, uma cogitada greve envolvendo os servidores públicos vinculados à segurança pública, como em cadeias e delegacias.

$\mathrm{Na}$ verdade, o que se pretende evidenciar é particularidade de cada movimento de greve, que contém um quadro fático próprio e requer um exame pela jurisprudência, caso a caso, à luz de suas nuances e peculiaridades. $^{257}$ Ou seja, competirá à casuística dizer se uma dada hipótese

âmbito da Administração Pública deve sofrer limitações, na medida em que deve ser confrontado com os princípios da supremacia do interesse público e da continuidade dos serviços públicos para que as necessidades da coletividade sejam efetivamente garantidas. Nesse aspecto, o eminente Ministro Gilmar Mendes, ao proferir seu voto nos autos da Rcl 6.568/SP, ressalvou que 'a análise de cada caso, a partir das particularidades do serviço prestado, deve realizar-se de modo cauteloso com vista a preservar ao máximo a atividade pública, sem, porém, afirmar, intuitivamente, que o movimento grevista é necessariamente ilegal' (DJe de 25/09/09; fl. 786 - sem destaques no original)." (BRASIL. Superior Tribunal de Justiça. Pet. 7939/DF, Relator Ministro Castro Meira, disponibilizado no DJe de 16/08/2010. Disponível em http://www.stj.jus.br. Acesso em 20/11/2010.

${ }^{256}$ O STF, no julgamento do citado Mandado de Injunção 670/ES, consignou que "no setor público, não se deve falar em 'atividades essenciais' ou 'necessidades inadiáveis', mas que as atividades estatais não podem ser interrompidas totalmente, sem qualquer condição, tendo em vista o princípio da continuidade dos serviços públicos."

${ }^{257}$ O Superior Tribunal de Justiça firmou este entendimento, em ponto de vista compartilhado por Ana Maria Goffi Flaquer Scartezzini, que assevera: "Remete-se a questão à definição da essencialidade dos serviços que deverão ser mantidos, pelo menos em mínima assistência à população. Em alguns casos, dúvida inexistirá sobre a natureza essencial do serviço; em outros, restará caracterizada a não essencialidade e, portanto, a integralidade do direito de greve. $\mathrm{Na}$ 
traduz serviço público essencial e fixar, em função disso, se e em que medida a greve pode ser permitida. ${ }^{258}$

Frise-se ser totalmente desimportante perquirir a quem compete o exercício do serviço prestado, ou seja, averiguar se o serviço público é prestado diretamente pela Administração, ou se, diversamente, o é por entidade paraestatal ou por particular. Em qualquer caso, uma vez reconhecida a essencialidade do serviço, a paralisação não estará autorizada - ao menos não legitimamente.

Significa dizer, em suma, que a limitação ao direito de greve dos servidores públicos justifica-se exatamente pela natureza desses serviços prestados, ou seja, porque são públicos e essenciais, imperando o interesse geral da coletividade não se autorizará a paralisação.

\subsection{A garantia da continuidade da Administração Pública sob outro enfoque: a substituição no exercício das funções públicas}

Um último ponto, neste trabalho, exige reflexão de nossa parte, porque se evidencia como uma das facetas da garantia da continuidade no âmbito da Administração Pública.

zona cinzenta da definição do conceito, só o exame caso a caso poderá determinar o exato alcance desse direito." (SCARTEZZINI. Ana Maria Goffi Flaquer. $O$ Princípio da Continuidade do Serviço Público. São Paulo: Malheiros Editores, 2006, p. 107).

${ }^{258}$ De maneira análoga, José Manoel de Arruda Alvim Netto atribuiu à casuística a tarefa de fixar o que seria dotado do significado de "arguição de relevância" (hoje, repercussão geral). Em obra clássica, o autor acentua a importância da tópica, para o cumprimento deste mister, em pensamento válido para este item, pelo que recomendamos a leitura de ARRUDA ALVIM, José Manoel de. A arguição de relevância no recurso extraordinário. São Paulo: Revista dos Tribunais, 1988, pp. 92 e ss. 
Quando se fala em funcionamento contínuo e regularidade da atividade administrativa, está se falando não só da necessidade de continuidade do serviço público, mas também se deve ter em vista a continuidade da própria Administração.

Com efeito, se compete à Administração, por intermédio de seus agentes, proporcionar o bem estar coletivo (sendo esta a finalidade pública, o objetivo de todo o atuar administrativo), avulta a importância da manutenção dos quadros da Administração Pública, de molde a que não se veja impossibilitada de desempenhar suas funções.

A doutrina brasileira não tem tratado desenvolvidamente dessa faceta, por assim dizer, do princípio da continuidade dos serviços públicos. O tema é, no entanto, bastante importante, pelo que vamos tentar abordá-lo aqui, ainda que se pretensão alguma à sua exaustão.

Neste momento, serão analisadas as figuras administrativas que garantem essa continuidade da própria Administração, medida que se afigura imprescindível para a persecução dos interesses da coletividade. De suma importância a análise dos instrumentos que garantem a substituição dos servidores públicos, ainda que de maneira bastante sucinta, para que os quadros da Administração Pública não sofram carências de servidores e, portanto, assegure-se não haja descontinuidade na prestação de nenhum dos desideratos da Administração.

Em função do que se expôs acima, emerge a necessidade da adoção de importantes institutos, tais como a delegação, a suplência e a substituição, com vistas ao preenchimento das funções públicas temporariamente vagas.

No direito estrangeiro, onde o tema é mais profunda e desenvolvidamente enfrentando, decisões recentes da Corte constitucional italiana, enfrentando o problema dos poderes de substituição de servidores, 
indicam o art. 97 da Constituição para evitar uma interrupção no exercício do poder: coisa que aparece gravemente lesiva do bom andamento em geral e, em particular, do princípio da continuidade, que é expressão do mesmo. ${ }^{259}$

Entre nós, como visto, o princípio da continuidade abrange tanto a continuidade dos serviços que são prestados aos administrados e remunerados diretamente por meio de tarifas (uti singuli), como também os serviços remunerados por meio de tributos (uti universi).

Porém, por ser um princípio um dos princípios informadores do regime jurídico-administrativo, reflete em na atividade administrativa como um todo, e não apenas em relação aos chamados serviços públicos. Por tal razão, o princípio da continuidade abrange toda a atividade administrativa, o que inclui o exercício de funções públicas.

Na Administração Pública direta, a atividade administrativa é exercida por servidores públicos, ocupantes de cargos públicos, que pode ser definido com "o conjunto de atribuições e responsabilidades cometidas a um servidor, criado por lei, em número certo, com denominação própria, remunerado pelos cofres públicos." ${ }^{260}$ O provimento de um cargo público se dá, via de regra, por meio de concurso público de provas ou de provas e títulos.

Em relação às atividades administrativas que são exercidas pelos servidores ocupantes de cargos públicos, estas devem ser exercidas de forma a não prejudicar a continuidade das atividades administrativas, visto que, conforme defendido, o princípio da continuidade é princípio informador de toda a atividade da Administração Pública.

Nesse sentido, Odete Medauar, com muita propriedade, ensina que: “O princípio da continuidade informa também as figuras da substituição,

${ }^{259}$ LEONE, Carmela. Il principio di continuità dell'azione amministrativa. Milão: Giuffrè, 2007, p. 132.

${ }^{260}$ MEDAUAR, Odete. Direito Administrativo Moderno. $10^{\mathrm{a}}$ ed. rev., atual. e ampl. São Paulo: RT, 2006, p. 131 
interinidade, suplência, o 'responder pelo expediente' os casos de vacância na chefia de órgãos e entidades." 261

A atividade administrativa, portanto, tem "natureza contínua e ininterrupta”, pois ao Poder Público é vedado interromper a prestação do serviço público - que, em sentido amplo, significa toda a atividade administrativa - em homenagem ao princípio da continuidade.

Com vista ao cumprimento da continuidade, a Lei 8.112/90 - o Estatuto dos Servidores Públicos Civis da União -, no Capítulo III do Título II, estabelece o instituto da substituição, nos artigos 38 e $39 .^{262}$

Da mesma forma, o Estatuto dos Funcionários Públicos Civil do Estado de São Paulo - Lei 10.261/68 - estabelece a substituição nos artigos 23 a $25 .^{263}$

${ }^{261}$ MEDAUAR, Odete. Direito Administrativo Moderno. $10^{\mathrm{a}}$ ed. rev., atual. e ampl. São Paulo: RT, 2006, p. 131.

262 Art. 38. Os servidores investidos em cargo ou função de direção ou chefia e os ocupantes de cargo de Natureza Especial terão substitutos indicados no regimento interno ou, no caso de omissão, previamente designados pelo dirigente máximo do órgão ou entidade. (Redação dada pela Lei $\mathrm{n}^{\circ}$ 9.527, de 10.12.97).

$\S 1^{\circ}$ O substituto assumirá automática e cumulativamente, sem prejuízo do cargo que ocupa, o exercício do cargo ou função de direção ou chefia e os de Natureza Especial, nos afastamentos, impedimentos legais ou regulamentares do titular e na vacância do cargo, hipóteses em que deverá optar pela remuneração de um deles durante o respectivo período. (Redação dada pela Lei $\mathrm{n}^{\circ}$ 9.527, de 10.12.97).

$\S 2^{\circ}$ O substituto fará jus à retribuição pelo exercício do cargo ou função de direção ou chefia ou de cargo de Natureza Especial, nos casos dos afastamentos ou impedimentos legais do titular, superiores a trinta dias consecutivos, paga na proporção dos dias de efetiva substituição, que excederem o referido período. (Redação dada pela Lei $n^{\circ} 9.527$, de 10.12.97).

Art. 39. O disposto no artigo anterior aplica-se aos titulares de unidades administrativas organizadas em nível de assessoria.

${ }^{263}$ Art. 23. Haverá substituição no impedimento legal e temporário do ocupante de cargo de chefia ou de direção.

Parágrafo único. Ocorrendo a vacância, o substituto passará a responder pelo expediente da unidade ou órgão correspondente até o provimento do cargo.

Art. 24. A substituição, que recairá sempre em funcionário público, quando não for automática, dependerá da expedição de ato de autoridade competente.

$\S 1^{\circ}$ - O substituto exercerá o cargo enquanto durar o impedimento do respectivo ocupante. 
Para ilustrar, o Parecer n. ${ }^{\circ}$ 102/2005, da Procuradoria-Geral da República de Portugal, nos traz uma melhor compreensão sobre o instituto da substituição:

Para a devida compreensão da figura jurídica da substituição do exercício de funções, aqui presente, há que convocar um dos princípios gerais do exercício da actividade administrativa: o princípio da continuidade dos serviços públicos, segundo o qual a continuidade dos serviços públicos deve ser assegurada em todas as circunstâncias. Por força dos interesses públicos que lhe cabe prosseguir, a actividade administrativa é por natureza contínua e ininterrupta. ${ }^{264}$

Nos termos estabelecidos pela legislação federal e do Estado de São Paulo, a substituição ocorre, em regra, nos casos de vacância de cargos ou funções de direção ou chefia, evitando-se, assim, a ausência de comando no órgão ou entidade administrativa.

Significa dizer que, no que tange à continuidade da atividade administrativa - serviço público em sentido amplo -, a substituição busca manter, de forma constante, um agente público responsável funcionalmente pela efetivação dessa atividade, visando a não interrupção da prestação, quer seja

$\S 2^{\circ}$ - O substituto, durante todo o tempo em que exercer a substituição, terá direito a perceber o valor do padrão e as vantagens pecuniárias inerentes ao cargo do substituído e mais as vantagens pessoais a que fizer jus.

$\S 3^{\circ}$ - O substituto perderá, durante o tempo da substituição, o vencimento ou a remuneração e demais vantagens pecuniárias inerentes ao seu cargo, se pelo mesmo não optar.

Art. 25. Exclusivamente para atender a necessidade de serviço, os tesoureiros, caixas e outros funcionários que tenham valores sob sua guarda, em caso de impedimento, serão substituídos por funcionários de sua confiança, que indicarem, respondendo a sua fiança pela gestão do substituto.

Parágrafo único. Feita a indicação, por escrito, ao chefe da repartição ou do serviço, este proporá a expedição do ato de designação, aplicando-se ao substituto a partir da data em que assumir as funções do cargo, o disposto nos $\S \S 1^{\circ}$ e $2^{\circ}$ do art. 24.

${ }^{264}$ PORTUGAL. Procuradoria Geral da República. Parecer $n^{\circ}$ 102/2005. Diário da República, $2^{\mathrm{a}}$ série, $\mathrm{n}^{\mathrm{o}} 51, \quad \mathrm{de}$ 13/03/2007. Disponível em internet: <http://www.dre.pt/pdf2sdip/2007/03/051000000/0682206827.pdf>. Acesso em 10/02/2011. 
para o usuário - contribuinte, portanto - quer seja no âmbito interno da Administração Pública. ${ }^{265}$

Quanto à figura da delegação, Juan Carlos Cassagne afirma tratarse de exceção ao princípio da improrrogabilidade da competência. Distinguindo a delegação administrativa da legislativa afirma que o instituto da delegação consubstancia técnica "que traduz a possibilidade de produzir o desprendimento de uma faculdade por parte de um órgão que transfere seu exercício a outro."266

Há, ainda, a figura da suplência, instituto inconfundível com a delegação, já que nela - diversamente do que ocorre na delegação - não há uma transferência de competência de um órgão a outro, mas apenas uma mudança na titularidade do órgão, transferência essa resulta de uma impossibilidade do titular exercer a sua competência no órgão. ${ }^{267}$ Para Juan Carlos Cassagne

"La suplência, en principio, no repercute em la competência del órgano cuyo titular no pueda ejercerla (v.gr. en caso de enfermedad). Ella se efectúa ope legis, en forma automática, siendo total, a diferencia de la delegación, que sólo puede referirse a competencias concretas y requiere una declaración de voluntad del delegante."

Com o desenho deste esboço fica fácil a compreensão da relação que se estabelece entre o objeto de nosso trabalho e as figuras em estudo: por intermédio de tais institutos, permite-se, mais eficazmente, garantir a não interrupção da Administração Pública.

\footnotetext{
${ }^{265}$ Com contornos algo diversos, Juan Carlos Cassagne caracteriza assim a figura da substituição: "La sustitución se funda, em canbio, en las prerrogativas de control que tiene el órgano superior sobre ele inferior y procede en supuestos de deficiente administración o abandono de funciones en que incurra el órgano que es sustituido. La sustitución configura una excepción al principio de la improrrogabilidad de la competencia siendo necesario que una norma expresa la autorice (CASSAGNE, Juan Carlos. Decrecho administrativo. 7. ed. Buenos Aires: Abeledo-Perrot, 2002, 285-286).

${ }^{266}$ Ibidem, p. 283.

${ }^{267}$ Ibidem, pp. 285-286.
} 
Em suma, evidencia-se que a Administração Pública procura efetivar o princípio da continuidade dos serviços públicos, em sentido amplo, abrangendo toda a atividade administrativa exercida pelos agentes públicos em geral, o que inclui não apenas os serviços públicos, mas também as atividades internas da Administração Pública, mantendo a chefia ou diretoria do órgão ou repartição continuamente em exercício, ainda que o titular do cargo esteja ausente, qualquer que seja o motivo. Evita-se, pois, a vacância desses cargos, com vista ao bom andamento da atividade.

\subsection{Perfil e objeto do princípio da continuidade: notas de encerramento}

A continuidade do serviço público, princípio representativo, a um só tempo, de um dever da Administração e de um direito do usuário, há de ser compreendida a partir de suas mais relevantes marcas, identificadas após a realização de nossa pesquisa.

A primeira delas é a inegável raiz constitucional que a exigência da continuidade dos serviços públicos ostenta. Conquanto não expressamente prevista no texto constitucional, é inocultável o fato de emergir, como desdobramento, de outros princípios guias da relação jurídico-administrativa.

Nos termos do quanto fixamos alhures, em decorrência da obrigatoriedade do desempenho da atividade administrativa a que se encontra sujeita, a Administração Pública submete-se ao dever de continuidade de seu agir, que não pode parar. Justamente em razão disso é que os agentes administrativos, submetidos a este mesmo 'dever' (o de cuidar do interesse público), não podem deixar de seguir essa finalidade cogente, devendo fazê-lo de 
maneira contínua, ininterruptamente. É o que apregoa Carmela Leone, com oportunidade:

O princípio de continuidade constitui, portanto, uma expressão do principio de bom andamento e representa uma necessidade imanente pela tutela do interesse público. Poderia se dizer, então, que o principio de continuidade funda-se no padrão constitucional e além disso também sobre a atribuição a uma administração de um objetivo público. ${ }^{268}$

A continuidade é, também, faceta ou desmembramento do princípio da eficiência. Com efeito, submetida ao princípio da continuidade, a Administração Pública (ou o particular, concessionário ou permissionário) está expressamente impedida de interromper a prestação dos serviços que disponibiliza. Tal interrupção, como é natural e ficou claro de nossa pesquisa, só pode derivar do comparecimento de uma hipótese excepcional, prevista em lei como hábil a tanto.

Porém, embora a exigência da continuidade dos serviços decorra da própria cláusula da eficiência, com ela não se confunde. Destaca-se a advertência de Carmela Leone:

A eficácia da ação administrativa exprime, como se sabe, a idoneidade da ação a conseguir os resultados programados e isso implica uma verificação entre os resultados obtidos e aqueles previstos. Frequentemente é relacionado (além do que ao princípio do bom andamento) aos princípios de razoabilidade $\mathrm{e}$ proporcionalidade, já que a abrangência das aplicações do princípio de eficácia torna difícil a distinção desse princípio dos outros. Em relação ao principio de continuidade [o princípio da eficiência] é de dimensões e aplicação mais generalizada, no sentido que o princípio de continuidade seria um "minus" respeito à eficácia, um nível

${ }^{268}$ LEONE, Carmela. Il principio di continuità dell'azione amministrativa. Milão: Giuffrè, 2007, p. 133 (tradução livre do autor). 
mínimo de garantia de uma ação eficaz, um minimum irrenunciável, expressando a mera necessidade que a ação administrativa elimine todos os obstáculos que a impeçam de funcionar. Isso significa que, sob o perfil da organização, uma ação tem mais chances de alcançar os objetivos estabelecidos quanto mais não sofre interrupções na execução dos mesmos. Mas representa também, segundo quanto já afirmado, um "prius", respeito à eficácia, que claramente implica uma pós avaliação. ${ }^{269}$

Enfim, o princípio de continuidade contribui à eficiência da atividade administrativa na medida em que indica preventivamente os modos e os instrumentos através dos quais impede que a função se interrompa. ${ }^{270}$

A continuidade na prestação dos serviços é, a nosso ver então, condição para que o serviço público seja adequado.

Para além disso, o princípio da continuidade, antes de ser um comando ou uma exigência que recai sobre o serviço público, é elemento que integra a própria essência do serviço público, que é a de perseguir e realizar a finalidade pública.

Acresça-se, neste contexto, a advertência feita por Carmela Leone, no sentido de que o princípio da continuidade não leva em consideração a expectativa do cidadão quanto ao correto exercício da ação administrativa: "A violação do princípio de continuidade é, visando perseguir o fim público no caso concreto, um mal em si [necessário], independente da lesão de uma posição subjetiva." 271

É, portanto, um princípio que bem se encaixa comodamente dentro de vários princípios diretores do direito administrativo, em particular o da

\footnotetext{
${ }^{269}$ LEONE, Carmela. Il principio di continuità dell'azione amministrativa. Milão: Giuffrè, 2007, p. 144 (tradução livre do autor).

${ }^{270}$ LEONE, Carmela, ibid., p. 145.

${ }^{271}$ Ibidem, mesma página (tradução livre do autor).
} 
preponderância do interesse público sobre o interesse privado, o da indisponibilidade do interesse público, da obrigatoriedade da ação administrativa e, por fim, no da exigência de uma ação eficiente (princípio da eficiência).

Mas é também, acima de tudo, critério para a escolha não apenas do administrador, mas em especial do legislador, como se vê, de fato, da disciplina que a matéria recebeu em vários textos normativos, em que sobrelevam e ficam evidentes o sopesamento e a ponderação (portanto, com proporcionalidade e razoabilidade) dos valores envolvidos. Neste sentido, por exemplo, a Lei de Concessões e Permissões, em particular o rol de hipótese de interrupção do serviço público trazidos pelo art. 6 . $^{\circ}$

Todas as soluções encontradas no assunto consideram, de perto, a atenção e observância necessárias a três requisitos: adequação (ou seja, um nexo de pertinência), necessidade e proporcionalidade em sentido estrito (esta, a exemplo do que se passa na adequação, visualizada na efetiva proporcionalidade entre a medida tomada e o resultado almejado). Essas soluções haverão de pautar não apenas o administrador mas, como igualmente se viu, o legislador.

Por isso é que se diz que o princípio da continuidade não tem valor absoluto.

No trato do tema é imperativa uma constante análise da relação meio-fim, de molde a tentar-se alcançar o equilíbrio necessário entre interesses supostamente conflitantes: os direitos dos administrados e as prerrogativas da Administração.

Frise-se, pois, que a garantia do princípio da continuidade dos serviços públicos exigirá, aqui e ali, restrições a determinados 'direitos', quer dos prestadores (como no caso da limitação da greve em serviços públicos essenciais), quer dos usuários (casos de interrupção por inadimplência). Mas, como se procurou evidenciar também, tais limitações representam, antes de tudo, conformações. 
Assume-se, neste trabalho, a noção de que as soluções apresentadas pela lei ordinária (quer na Lei de Concessões e Permissões, quer na Lei de Greve, quer em outros eventuais diplomas normativos) conformam o sentido de continuidade emergido implicitamente do texto constitucional. Diferentemente da limitação, que traz a ideia de excesso (e, por isso, de algo que ficou fora), a conformação está mais associada à noção de ajuste, de moldar-se dentro do próprio conceito.

Por isso afigura-se mais legítimo, em nossa opinião, falar em conformação do conceito e do significado do princípio da continuidade, e não em exceções ao princípio. Ou, em outras palavras, poder-se-ia sustentar que essas "restrições" ou "exceções" conformam o princípio da continuidade.

Portanto, se há atividades que nunca podem parar, em relação a estas não se pode admitir a interrupção do serviço (quer por 'corte' ante eventual inadimplemento, quer pela garantia ao exercício do direito de greve) todas as vezes em que se estiver diante de um interesse público ou coletivo, maior que o individual. Ante situações consideradas como de necessidades inadiáveis expressão cunhada pela lei de Greve (Lei n. 7.783/89) - ou seja, as que coloquem em perigo iminente a sobrevivência, a saúde ou a segurança da população, a solução há de ser tomada casuisticamente, ou seja, a partir de um exame caso a caso.

Vale destacar também a advertência feita anteriormente, quanto à importante distinção entre aquilo que é contínuo e o que é regular. O serviço contínuo é que funciona sem interrupções, sem falhas no seu funcionamento; é regular, a seu turno, quando opera sempre no mesmo ritmo. Exemplo emblemático e válido da distinção - e altamente elucidativo - nos é fornecido por José Roberto Dromi: a regularidade diz respeito aos horários do ônibus de 
transporte público; a continuidade o serviço de transporte público propriamente dito, quanto à sua não paralisação ou interrupção. ${ }^{272}$

${ }^{272}$ DROMI, José Roberto. Derecho administrativo. Tomo 2. Buenos Aires: Ástrea, 1992, p. 9. 


\section{CONSIDERAÇÕES FINAIS}

A Constituição de 1988, atribuindo ao Poder Público a titularidade para a prestação dos serviços públicos, estabeleceu que tal prestação poderia ocorrer de maneira direta, ou mediante execução indireta (cf dizeres do art. 175, CF). Deixou, porém, o legislador constituinte - e o mesmo fez o ordinário - de delimitar o conceito de serviços públicos.

Não sem muita polêmica e dificuldade, coube à doutrina a árdua tarefa de precisar-lhe o conceito. De maneira bastante simples, serviço público é a atividade prestacional da Administração de oferecimento e promoção das necessidades dos administrados.

Consequência de relevo do reconhecimento de que uma dada atividade é serviço público, como dantes assinalado e aqui repisado, é a sua submissão a um grupo de preceitos. Em outras palavras, assumir uma dada atividade como serviço público implica reconhecer a sua sujeição aos princípios guias da atividade administrativa, dentre os quais nos interessa, em particular e de maneira acentuada, a exigência de que o serviço seja prestado continuamente, sem interrupções.

Situações "limítrofes" e que, supostamente, contrastariam a incidência do postulado da continuidade foram também enfrentadas, notadamente as repercussões da continuidade que se projetam no campo dos contratos administrativos (em particular, os de concessão e permissão de serviços públicos) e, de outro lado, no regime dos servidores e nas que impactam no exercício das funções públicas.

O enfrentamento dessas situações emblemáticas permitiu-nos entrar em contato com questões de imenso relevo e perceber que a exigência da continuidade nos serviços públicos não é valor absoluto. 
Assentadas as necessárias premissas, apuramos que a continuidade do serviço público é postulado representativo, a um só tempo: (i) de um dever da Administração e, também, (ii) de um direito do administradousuário.

A inocultável feição constitucional do princípio da continuidade, reconhecidamente um desdobramento de outros princípios guias da relação jurídico-administrativa, aproxima-o e relaciona-o com vários dos postulados que norteiam o atuar administrativo. É princípio que bem se encaixa comodamente dentro de vários princípios diretores do direito administrativo, em particular o da preponderância do interesse público sobre o interesse privado, o da indisponibilidade do interesse público, da obrigatoriedade da ação administrativa e, por fim, no da exigência de uma ação eficiente (princípio da eficiência).

De maneira bastante acentuada, essa relação se estabelece entre a continuidade e o princípio da eficiência, sem que se possa, porém, confundi-los.

A continuidade na prestação dos serviços coloca-se como condição para que o serviço público seja adequadamente prestado (e, preferencialmente, de maneira eficiente). Mas, acima de tudo, o que se demonstrou foi que o tema de nosso trabalho, antes de consubtanciar um vetor ou exigência dos serviços públicos, é elemento, parte integrante do próprio significado e da essência do serviço público.

Não se deve compreender, pelo princípio da continuidade, uma vedação à paralisação da atividade administrativa, que estará autorizada em determinadas situações - excepcionais, previstas em lei e desde que não haja um interesse coletivo maior, hábil a justificar a manutenção do serviço.

Além de pautar a ação do administrador, como se vê à evidência, a continuidade serve de guia também para o legislador. Realmente, a disciplina que a matéria recebeu em vários textos normativos, em que sobrelevam e ficam evidentes o sopesamento e a ponderação (portanto, com proporcionalidade e 
razoabilidade) dos valores envolvidos. Neste sentido, e.v., temos a Lei de Concessões e Permissões, em particular o rol de hipótese de interrupção do serviço público trazidos pelo art. 6. ${ }^{\circ}$, e também a própria Lei de Greve.

Apuramos, pois, que a garantia do princípio da continuidade dos serviços públicos exige, aqui e ali, restrições a determinados 'direitos', quer dos prestadores (como no caso da limitação da greve em serviços públicos essenciais), quer dos usuários (casos de interrupção por inadimplência). Mas, como se procurou evidenciar também, as chamadas limitações representam, antes de tudo, conformações.

Por isso afigura-se mais legítimo, em nossa opinião, falar em conformação do conceito e do significado do princípio da continuidade, e não em exceções ao princípio. Ou, em outras palavras, poder-se-ia sustentar que essas "restrições" ou "limitações" examinadas neste trabalho, em verdade, conformam o princípio da continuidade dentro do seu significado constitucional e de princípio geral/guia da relação jurídico-administrativa.

Nessa mesma linha, concluiu-se pela impossibilidade do princípio da continuidade justificar - ou de qualquer modo exigir - a inaplicabilidade à Administração da exceptio non adimplenti. Em realidade, a impossibilidade da invocação dessa cláusula pelo particular há de ser lida com reservas, sob pena de inviabilização do contrato e, por vezes, do próprio particular/empresa.

Não há, enfim, solução "pronta": exigir-se-á, a todo o momento, uma atenção especial aos princípios da proporcionalidade e razoabilidade com vistas à correta identificação do proceder da Administração. 
O necessário equilíbrio entre os interesses em jogo - prerrogativas da Administração versus direitos dos usuários - demandará o constante sopesamento dos valores e das circunstâncias envolvidas, caso e caso. 


\section{REFERÊNCIAS BIBLIOGRÁFICAS}

ALEXY, Robert, Teoria dos direitos fundamentais. Tradução de Virgílio Afonso da Silva. São Paulo: Malheiros Editores, 2008.

ALMEIDA, Fernando Dias Menezes de. Aspectos constitucionais da concessão de serviços públicos. In: MEDAUAR, Odete (Org.). Concessão de Serviço Público. São Paulo: Revista dos Tribunais, 1995.

. Novas Figuras Contratuais no Direito Administrativo. In: MEDAUAR, Odete (Org.). Licitações e Contratos Administrativos. 1. ${ }^{a}$ ed. São Paulo: NDJ, 1998.

AMAN JR., Alfred C., MAYTON, Willian T. Administrative Law. St. Paul, Minn: West Group. 2001.

AMARAL, Antônio Carlos Cintra do. Concessão de Serviço Público. 2. ${ }^{a}$ ed., rev., atual. e ampl., São Paulo: Malheiros Editores, 2002.

Distinção entre usuário de serviço público e consumidor. Revista Diálogo Jurídico, Salvador, CAJ - Centro de Atualização Jurídica, $\mathrm{n}^{\circ}$. 13, abrilmaio, 2002. Disponível na internet: 〈http://www.direitopublico.com.br〉. Acesso em 01.10.2010.

AMARAL, Diogo Freitas do. Curso de Direito Administrativo. 3..$^{\mathrm{a}}$ ed. Almedina: Coimbra, 2007. Vol. 1.

Curso de Direito Administrativo. 7. ${ }^{\mathrm{a}}$ reimpressão da ed. de 2001. Almedina: Coimbra, 2007. Vol. 2.

AMARAL FILHO, Marcos João Teixeira do. Privatização no Estado Contemporâneo. São Paulo: Ícone, 1996.

ARAGÃO, Alexandre Santos de. Direito dos Serviços Públicos. Rio de Janeiro: Forense, 2007. 
ARAÚJO, Edmir Netto de. Curso de Direito Administrativo, 3. ${ }^{\mathrm{a}}$ ed. São Paulo: Saraiva, 2007.

ARAÚJO, Maria Angélica Benetti. Autonomia da vontade no direito contratual. Revista de Direito Privado, n. 27, São Paulo: Revista dos Tribunais, jul./set. 2006.

ARRUDA ALVIM, José Manoel de. A arguição de relevância no recurso extraordinário. São Paulo: Revista dos Tribunais, 1988.

ARRUDA ALVIM, José Manoel de. Comentários ao Código Civil Brasileiro Do Direito das Coisas. ARRUDA ALVIM, José Manoel; ALVIM, Thereza (Coord.). Rio de Janeiro: GEN/Forense, 2009. Vol. XI, Tomo I.

; ALVIM, Eduardo Arruda; TAVOLARO, Luiz Antonio. Licitações $e$ Contratos Administrativos: Uma visão à luz dos Tribunais de Contas. Curitiba: Juruá, 2006.

ATAliBA, Geraldo. Mudança da Constituição. Revista de Direito Público. n. 86, São Paulo: Malheiros Editores, abr./jun.1988, pp. 181-186.

ÁVILA, Humberto Bergmann. A distinção entre princípios e regras e a redefinição do dever de proporcionalidade. Revista de Direito Administrativo 215, Rio de Janeiro: Renovar, 1999, p. 151-179.

AZEVEDO, Fernando Costa de. A suspensão do fornecimento de serviço público essencial por inadimplemento do consumidor-usuário. Argumentos doutrinários e entendimento jurisprudencial. Revista de Direito do Consumidor. v. 62. São Paulo: Revista dos Tribunais, abr./jun. 2007, p. 86-123.

BACELLAR FILHO, Romeu Felipe; BLANCHET, Alberto. Serviços Públicos: estudos dirigidos. Belo Horizonte: Fórum, 2007.

BASTOS, Celso Ribeiro. Curso de Direito Administrativo. 5. a ed., São Paulo: Saraiva, 2001.

BATISTA, Joana Paula. Remuneração dos Serviços Públicos. São Paulo: Malheiros Editores, 2005. 
BENJAMIN, Antônio Herman de Vasconcellos e et. al. Comentários ao Código de Proteção ao Consumidor, São Paulo: Saraiva, 1991.

BERNARDES, Juliano Taveira. Controle Abstrato de Constitucionalidade: Elementos Materiais e Princípios Processuais. São Paulo: Saraiva, 2004.

BERTONCINI, Eduardo Siqueira Nunes. Princípios de Direito Administrativo Brasileiro. São Paulo: Malheiros Editores, 2002.

BINENBOJM, Gustavo. A supremacia do interesse público sobre o particular ao dever de proporcionalidade: um novo paradigma para o direito administrativo. Revista de Direito Administrativo, v. 239. Rio de Janeiro: Renovar, jan./mar. 2005, p. 01-31.

BLANCHET, Luiz Alberto. Concessão e Permissão de Serviços Públicos. Curitiba: Juruá, 1995.

BORGES, Alice Maria Gonzalez. Temas do Direito Administrativo Atual: Estudos e Pareceres. Belo Horizonte: Fórum, 2004.

BREGA, José Fernando Ferreira. Lei Orgânica do Município de São Paulo Anotada. São Paulo: Páginas \& Letras Editora e Gráfica-Associação dos Procuradores do Município de São Paulo, 2006.

BUCCI, Maria Paula Dallari. Direito Administrativo e Políticas Públicas, São Paulo: Saraiva, 2002.

CAETANO, Marcello. Manual de Direito Administrativo, 10. ${ }^{\mathrm{a}}$ ed. Coimbra Portugal: Livraria Almedina, 2001. vol. I.

CAETANO, Marcello. Manual de Direito Administrativo, 10. ${ }^{\text {a }}$ ed. Coimbra Portugal: Livraria Almedina, 1999. vol. II.

Manual de Direito Administrativo. 10. ${ }^{\mathrm{a}}$ ed. 6. ${ }^{\mathrm{a}}$ reimp. Porto: Almedina, 1999. Tomo II.

. Princípios fundamentais do direito administrativo. Rio de Janeiro: Forense, 1989. 
CALAIS-AULOY, Jean; STEINMETZ, Frank. Droit de la consommation. 4. ${ }^{\mathrm{a}}$ ed. Paris: Dalloz, 1996.

CANOTILHO, José Gomes. Direito Constitucional. 3. a ed., Coimbra: Almedina, 1983.

CARVAlHO FILHO, José dos Santos. Manual de Direito Administrativo (Remissões ao Novo Código Civil). 9. a edição. Rio de Janeiro: Editora Lumen Juris, 2002.

CAVALCANTI, Themistocles Brandão. Tratado de Direito Administrativo, 5. ${ }^{a}$ ed., São Paulo: Livraria Freitas Bastos, 1964. Vol. I-V.

COELHO, Paulo Magalhães da Costa. Manual de Direito Administrativo, São Paulo: Saraiva, 2004.

COSTAldello, Angela Cassia. Serviço Público - Direitos Fundamentais, Formas Organizacionais e Cidadania. Curitiba: Juruá, 2005.

CRETELLA JÚNIOR, José. Curso de direito administrativo. 14. ${ }^{\mathrm{a}}$ ed. Rio de Janeiro: Forense, 2002.

CUNHA JÚNIOR, Dirley da. Controle Judicial das Omissões do Poder Público. São Paulo: Saraiva, 2004.

D’ALESSIO, Francesco. Instituzioni di Diritto Amministrativo Italiano. Torino: Unione Tipografico - Editrice Torinese, 1932. Vol. I.

DI PIETRO, Maria Sylvia Zanella. Direito Administrativo. 20. ${ }^{\text {a }}$ ed. São Paulo: Atlas, 2007.

Parcerias na Administração Pública: concessão, permissão, franquia, terceirização e outras formas, 4. a ed. São Paulo: Atlas, 2002.

DIAS, Eduardo Rocha. Sanções Administrativas Aplicáveis a Licitantes e Contratados. São Paulo: Dialética, 1997. 
DIAS, Jefferson Aparecido. Princípio da eficiência e moralidade administrativa - a submissão do princípio da eficiência à moralidade administrativa na Constituição Federal de 1988. Curitiba: Juruá, 2004.

DONADO, Maria Antonieta Zanardo. Proteção ao consumidor: conceito e extensão. São Paulo: Revista dos Tribunais, 1993.

DROMI, José Roberto. Derecho Administrativo. Buenos Aires: Astrea, 1992. Tomos 1 e 2 .

. Introduccion al Derecho Administrativo, Madrid: Editorial Grouz, 1986.

Sistema Jurídico e Valores Administrativos. Porto Alegre: Sérgio Antônio Fabris, 2007.

ECO, Umberto. Como se faz uma tese. 19. a ed. São Paulo: Perspectiva, 2005.

ENTERRÍA, Eduardo García de e FERNÁNDEZ, Tomás-Ramón. Curso de Direito Administrativo, São Paulo: Editora Revista dos Tribunais, 1990.

FERRAZ, Tércio Sampaio. Introdução ao Estudo do Direito: Técnica, Decisão. São Paulo: Atlas, 1988.

FIGUEIREDO, Lúcia Valle. Curso de Direito Administrativo, 2. ${ }^{\mathrm{a}}$ ed., São Paulo: Malheiros Editores, 1995.

FIGUEIREDO, Marcelo; PONTES FILHO, Valmir. Estudos de Direito Público em homenagem a Celso Antônio Bandeira de Mello, São Paulo: Malheiros Editores, 2006.

FILHO, Marçal Justen. Comentários à Lei de Licitações e Contratos Administrativos, de acordo com a Lei Federal n. ${ }^{\circ} 8.883$, de 08/06/1994. 4. ${ }^{a}$ ed. Rio de Janeiro: Aide Editora, 1996.

FILOMENO, José Geraldo Brito. Manual de Direitos do Consumidor. 8. ${ }^{\mathrm{a}}$ ed. São Paulo: Atlas, 2005. 
Promotorias de justiça do Consumidor: Evolução. Metas e Prioridades. Revista Justitia, São Paulo, v. 54, n. 160, out./dez. 1992, pp. 204-235.

FRANÇA, Vladimir da Rocha. Invalidação Judicial da Discricionariedade Administrativa: no Regime Jurídico-Administrativo Brasileiro. Rio de Janeiro: Renovar, 2000.

FREITAS, Juarez, Discricionariedade Administrativa e o Direito Fundamental à Boa Administração. São Paulo: Malheiros Editores, 2007.

GALETTA, Diana Urania. Principio di proporzionalita e sindacato giurisdizionale nel diritto amministrativo. Milão: Giuffrè, 1998.

GARRIDO FALLA, Fernando. Tratado de Derecho Administrativo - Vol. 1: Parte General. Madrid: Editorial Tecnos, 2005.

GASPARINI, Diógenes. Direito Administrativo. 11. a ed. São Paulo: Saraiva, 2006.

GORDILLO, Agustín. Princípios gerais de direito público. São Paulo: Saraiva, 1977.

. Tratado de Derecho Administrativo [La defensa del usuario y del administrado]. 5. a ed. Belo Horizonte: Del Rey e Fundación de Derecho Administrativo, 2003. Tomo 2.

GOYANES, Enrique Sánchez. Manual de Derecho Administrativo. Madrid: COLEX, 1997. Vol. II.

GRAU, Eros Roberto. Constituição e serviço público. In: GRAU, Eros Roberto; GUERRA FILHO, Willis Santiago. Direito Constitucional - estudos em homenagem a Paulo Bonavides, São Paulo: Malheiros Editores, 2001.

Suspensão do fornecimento de energia elétrica: constitucionalidade, Código do Consumidor, princípios e postulados normativos aplicativos da razoabilidade e da proporcionalidade. Revista Trimestral de Direito Público, São Paulo: Malheiros Editores, v. 36, 2001, p. 137-149. 
GRINOVER, Ada Pellegrini. Et. al. Código Brasileiro de Defesa do Consumidor comentado pelos autores do Anteprojeto. 8. ${ }^{a}$ ed. Rio de Janeiro: Forense Universitária, 2004.

GROTT, Dinorá Adelaide Mussetti. O Serviço Público e a Constituição Brasileira de 1988. São Paulo: Malheiros Editores, 2003.

HARGER, Marcelo. Princípio da Eficiência. Repertório IOB de Jurisprudência, São Paulo, v. 01, n. 16, $2^{\circ}$ quinz. ago. 1999, pp. 491-493.

ITALIA Vittorio, LANDI Guido e POTENZA Giuseppe. Manuale di Diritto Amministrativo - XII edizione, Milão: Giuffrè, 2000.

JUNGSTEDT, Luiz Oliveira Castro. Direito Administrativo: Legislação. $8^{\circ}$ edição revista e atualizada. Rio de Janeiro: Thex Editora, 2000.

JUSTEN FILHO, Marçal. Curso de Direito Administrativo. $2^{\mathrm{a}}$ rev. e atual. São Paulo: Saraiva, 2006.

- Teoria Geral das Concessões de Serviço Público, São Paulo: Dialética, 2006.

LEONE, Carmela. Il principio di continuità dell'azione amministrativa. Milão: Giuffrè, 2007.

LIMONGI FRANÇA, R. Princípios Gerais de Direito, São Paulo: Revista dos Tribunais, 1971.

LUCCA, Newton de. Direito do consumidor: aspectos práticos: perguntas e respostas. São Paulo: Revista dos Tribunais, 1995.

MARÍN, Antonio Martinez. El Buen Funcionamento de los Servicios Publicos (Los Principios de Continuidad y de Regularidad). Madrid: Editorial Tecnos, 1990.

MARINI, Francesco Saverio. Il principio di continuita degli organi constituzionali, Milão: Giuffrè, 2007. 
MARQUES, Cláudia Lima. BENJAMIN, Antônio Herman V. MIRAGEM, Bruno. Comentários ao Código de Defesa do Consumidor. 2. a ed. São Paulo: Revista dos Tribunais, 2006.

Contratos no Código de Defesa do Consumidor: o novo regime das relações contratuais. 4. ${ }^{\mathrm{a}}$ ed. São Paulo: Revista dos Tribunais, 2002.

MARQUES NETO, Agostinho Ramalho. A ciência do direito: conceito, objeto, método. Rio de Janeiro: Renovar, 2001.

MARQUES NETO, Floriano Azevedo. Reajuste e revisão nas parcerias públicoprivadas: revisitando o risco nos contratos de delegação. In: SOUZA, Mariana Campos de (Org.). Parceria Público-privada: aspectos jurídicos relevantes. São Paulo: Quartier Latin, 2008.

- Regulação Estatal e Interesses Públicos. São Paulo: Malheiros Editores, 2002.

MARTINS, Ives Gandra da Silva; BASTOS, Celso. Comentários à Constituição

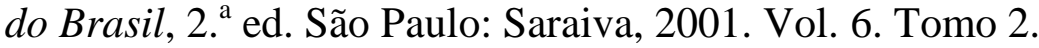

MASUCCI, Alfonso. Transformazione dell'Amministrazione e Moduli Convenzionali - Il Contratto di Diritto Pubblico, Napoli: Ed. Jovene, 1988.

MAURER, Hartmut. Direito Administrativo Geral. 14. ${ }^{\mathrm{a}}$ ed. rev. e comp. Barueri: Manole, 2006.

Elementos de Direito Administrativo Alemão. Porto Alegre: Sérgio Antonio Fabris, 2001.

MAURIN, Andre. Derecho Administrativo Francés. México: Librería de Porrua Hnos y Cía, 2004.

MEDAUAR, Odete. Direito Administrativo Moderno. 11. a ed. rev., atual. e ampl. São Paulo: Revista dos Tribunais, 2007.

Direito Administrativo Moderno. 10. ${ }^{\mathrm{a}}$ ed. rev., atual. e ampl. São Paulo: Revista dos Tribunais, 2006. 
O Direito Administrativo em Evolução. 2. ${ }^{\text {a }}$ ed. rev. atual. e ampl. São Paulo: Revista dos Tribunais, 2003.

Poder de polícia. Revista de Direito Administrativo. Rio de Janeiro, v. 199, jan./mar.1995, pp.89-96.

Serviço Público. Revista de Direito Administrativo. Rio de Janeiro, v. 189, jul/set. 1992.

Serviços públicos e serviços de interesse geral. In: MOREIRA NETO, Diogo de Figueiredo (Coord). Uma avaliação das tendências contemporâneas do Direito Administrativo - Anais do Seminário de Direito Administrativo Brasil - Espanha. Rio de Janeiro: Renovar, 2003.

MEIRELLES, Hely Lopes. Direito Administrativo Brasileiro. 33. a edição, São Paulo: Malheiros Editores, 2007.

. Direito Administrativo Brasileiro. 29. a ed. São Paulo: Malheiros Editores, 2004.

Direito Municipal Brasileiro. 15. a ed. São Paulo: Malheiros Editores, 2006.

MELlO, Celso Antônio Bandeira de. Atos Administrativos e Direitos dos Administrados. São Paulo: Revista dos Tribunais, 1981.

- Conteúdo Jurídico do Princípio da Igualdade. 3. ${ }^{\mathrm{a}}$ ed. atual., 9. ${ }^{\mathrm{a}}$ tiragem, São Paulo: Malheiros Editores, 2001.

Curso de Direito Administrativo. 27. ${ }^{\text {a }}$ ed., rev. e atual., São Paulo: Malheiros Editores, 2010.

- Discricionariedade e controle jurisdicional. 4. ${ }^{\text {a }}$ ed. São Paulo: Malheiros Editores, 2002.

Prestação de Serviços Públicos e Administração Indireta. 2. ${ }^{\mathrm{a}}$ ed., 3. ${ }^{\mathrm{a}}$ tir. São Paulo: Revista dos Tribunais, 1987. 
MELLO, Oswaldo Aranha Bandeira de. Princípios Gerais de Direito Administrativo, 3. ${ }^{a}$ edição. São Paulo: Malheiros Editores, 2007. Vol. I.

Princípios Gerais de Direito Administrativo. Rio de Janeiro: Forense, 1974. Vol. II.

MEZZAROBA, Orides; MONTEIRO, Cláudia Sevilha. Manual de metodologia da pesquisa no direito. 2. ${ }^{\text {a }}$ ed. São Paulo: Saraiva, 2004.

MOREIRA NETO, Diogo de Figueiredo. Curso de Direito Administrativo. 14. ${ }^{\mathrm{a}}$ ed. Rio de Janeiro: Forense, 2005.

. Mutações do Direito Administrativo. 2. ${ }^{\mathrm{a}}$ ed. Rio de Janeiro: Renovar, 2001.

- Sociedade, Estado e Administração Pública, Rio de Janeiro: Topbooks, 1995.

MOURA, Mário Aguiar. O Poder Público como fornecedor perante o Código de Defesa do Consumidor. Repertório de jurisprudência IOB, São Paulo, 2. quinzena de abril/92.

MUKAI, Toshio. Concessões, Permissões e Privatizações de Serviços Públicos. 4. ${ }^{\text {a }}$ ed. São Paulo: Saraiva, 2002.

Direito Administrativo Sistematizado. São Paulo: Saraiva, 1999.

Licitações e Contratos Públicos: comentários à lei n. 8.666/93, com as alterações da lei n. 9.648/98 (reforma administrativa). 5. ${ }^{a}$ ed. atual., rev. e ampl., São Paulo: Saraiva, 1999.

NAMBA, Edison Tetsuzo. A suspensão do serviço público pela concessionária em decorrência do não pagamento das contas pelo usuário, Revista de Direito do Consumidor, v. 36. São Paulo: Revista dos Tribunais, out./dez. 2000, p. 130153.

NOBRE JUNIOR, Edilson Pereira. Administração pública e o princípio constitucional da eficiência. Revista de Direito Administrativo, v. 241. Rio de Janeiro: Renovar, jan./mar. 2005, p. 209-240. 
NUNES, Rizzatto. Comentários ao Código de Defesa do Consumidor. 2. ed. São Paulo: Saraiva, 2005.

OLIVEIRA, José Carlos de. Código de Proteção e Defesa do Consumidor: doutrina - jurisprudência - legislação complementar. Leme: LED, 1999. Concessões e Permissões de Serviços Públicos, Bauru: Edipro, 1996.

OLIVEIRA, José Roberto Pimenta. Os princípios da Razoabilidade e da Proporcionalidade no Direito Administrativo Brasileiro. São Paulo: Malheiros Editores, 2006.

OLIVEIRA, Maria José Galleno de Souza. A defesa dos usuários de serviços públicos concedidos no Brasil. São Paulo: Livraria Paulista, 2003.

OLIVEIRA, Regis Fernandes de. Delegação Administrativa. São Paulo: Revista dos Tribunais, 1987.

OSÓRIO, Fábio Medina. Existe uma Supremacia do Interesse Público sobre o Privado no Direito Administrativo Brasileiro? Revista de Direito Administrativo, v. 220. Rio de Janeiro: Renovar, abr./jul. 2000, p. 69-107.

PARADA, Ramon. Derecho Administrativo. 5. ${ }^{\text {a }}$ ed. Madrid: Ed. Marcial Pons, 1993. Tomo I.

PINHEIRO, Claudia Travi Pitta. A suspensão de serviço público em virtude do inadimplemento do usuário à luz dos princípios da boa-fé e da proporcionalidade. Revista de Direito do Consumidor. v. 40. São Paulo: Revista dos Tribunais, out./dez. 2001, p. 62-75.

PINTO, Bilac. Regulamentação Efetiva dos Serviços de Utilidade Pública, 2. ed. Rio de Janeiro: Forense, 2002.

REALE, Miguel. Lições Preliminares de Direito. 27. ed. São Paulo: Saraiva, 2002.

Lições Preliminares de Direito. 24. ${ }^{a}$ ed. São Paulo: Saraiva, 2000. 
REGINATO, Osvaldo Anselmo. A prestação do serviço público essencial de fornecimento de água tratada e os direitos constitucionais e do consumidor. Revista de Direito do Consumidor. v. 65. São Paulo: Revista dos Tribunais, jan./mar. 2008, pp. 192-225.

ROCHA, Carmen Lúcia Antunes. Princípios Constitucionais da Administração Pública. Belo Horizonte: Del Rey, 1994.

ROJAS, Francisco José Villar. Privatización de servicios públicos. Madrid: Tecnos, 1993.

SALOMONI, Jorge Luis. Teoría general de los servicios públicos. Buenos Aires: Ad-Hoc, 1999.

SÁNCHEZ. Juan José Díez. El Derecho de Huelga de los Funcionarios Públicos. Madrid: Universidad de Alicante/Civitas, 1990.

SANTAMARÍA PASTOR, Juan Alfonso. Principos de Derecho Administrativo General., Madrid: Iustel Publicaciones, 2004. Tomos I e II.

SARMENTO, Daniel. A ponderação de interesses na Constituição Federal. Rio de Janeiro: Lúmen Juris, 2002.

SCARTEZZINI, Ana Maria Goffi Flaquer. O princípio da continuidade do serviço público. São Paulo: Malheiros Editores, 2006.

SCHMIDT-ASSMANN, Eberhard. La Teoría General del Derecho Administrativo como Sistema Objeto y Fundamentos de la Construcción Sistemática. Madrid: Marcial Pons, Ediciones Jurídicas, 2003.

SILVA, José Afonso da. Curso de Direito Constitucional Positivo. 25. a ed. São Paulo: Malheiros Editores, 2005.

SOUTO, Marcos Juruena Villela. Direito Administrativo das Concessões, Rio de Janeiro: Editora Lumen Juris, 2004.

STIGLITZ, Gabriel. Protección jurídica del consumidor. 2. a ed. Buenos Aires: Depalma, 1990. 
SUNDFELD, Carlos Ari. Direito Administrativo Ordenador. São Paulo: Malheiros Editores, 1993.

TÁCITO, Caio. Direito Administrativo. São Paulo: Saraiva, 1975.

. Temas de Direito Público: Estudos e Pareceres. Rio de Janeiro: Renovar, 1997. Vol. 1.

- Temas de Direito Público: Estudos e Pareceres. Rio de Janeiro: Renovar, 1997. Vol. 2.

Temas de Direito Público: Estudos e Pareceres. Rio de Janeiro: Renovar, 2002. Vol. 3.

TELLES, Antonio A. Queiroz. Introdução ao Direito Administrativo. 2. ${ }^{\mathrm{a}} \mathrm{ed}$. rev., atual. e ampl., São Paulo: Revista dos Tribunais, 2000.

VELloso, Carlos Mario da Silva. Temas de Direito Público. 1. ${ }^{\mathrm{a}}$ ed., 2. ${ }^{\mathrm{a}}$ tiragem. Belo Horizonte: Del Rey, 1997. 